UNIVERSIDADE DE SÃO PAULO

FACULDADE DE FILOSOFIA, LETRAS E CIÊNCIAS HUMANAS

DEPARTAMENTO DE FILOSOFIA

\title{
A arqueologia de uma tensão: \\ o diagnóstico do presente de As palavras e as coisas
}

Dyogo Henrique Machado Gontijo Silva Leão

SÃO PAULO

2016 


\section{Dyogo Henrique Machado Gontijo Silva Leão}

\section{A arqueologia de uma tensão: o diagnóstico do presente de As palavras e as coisas}

Dissertação apresentada ao Programa de Pós-Graduação do Departamento de Filosofia da Faculdade de Filosofia, Letras e Ciências Humanas da Universidade de São Paulo, para a obtenção do título de Mestre em Filosofia.

Orientador: Maurício Cardoso Keinert

SÃO PAULO

2016 
Autorizo a divulgação total ou parcial deste trabalho, por qualquer meio convencional ou eletrônico, para fins de estudo e pesquisa, desde que citada a fonte. 
Nome: Leão, Dyogo H M G S

Título: A arqueologia de uma tensão: o diagnóstico do presente de $A s$ palavras e as coisas

Dissertação apresentada ao Programa de PósGraduação do Departamento de Filosofia da Faculdade de Filosofia, Letras e Ciências Humanas da Universidade de São Paulo, para a obtenção do título de Mestre em Filosofia.

Aprovado em:

Banca Examinadora

Prof. Dr.:

Instituição:

Julgamento:

Assinatura:

Prof. Dr.:

Instituição:

Julgamento:

Assinatura:

Prof. Dr.:

Instituição:

Julgamento:

Assinatura:

Prof. Dr.:

Instituição:

Julgamento:

Assinatura: 
Para Hélio e para Paula 


\section{Agradecimentos}

Ao professor Dr. Maurício Keinert, pela orientação cuidadosa e paciente, por ter estado sempre disponível ao longo do processo, mas também por ter me apoiado quando tive que lidar com os percalços da vida acadêmica.

Ao Ronaldo Manzi Filho, pelas leituras deste trabalho, pelas questões e sugestões. Este trabalho é, em grande parte, fruto das nossas longas conversas que, muitas vezes, só encontram limites no esgotamento físico e mental.

Ao Marcos Camolezi, parceiro nos rolês (a pé e sobre as rodinhas) nas cidades e no mato, sempre bom de prosa e com quem pude aprender muito nesses anos.

Ao Rafael Gargano, que testemunhou, desde o início, minha trajetória na filosofia.

Ao Lucas Carpinelli, pelos bons momentos que pude desfrutar durante nossas aulas de inglês.

À professora Dra. Monique Hulshof e ao Luís Gonzaga, cujas críticas e sugestões foram muito importantes para que este trabalho começasse a sair de si mesmo.

Ao professor Dr. Diogo Sardinha, por ter me recebido durante o estágio em Paris e por ter me apresentado diversas possibilidades quanto a como continuar o texto da qualificação.

À professora Dra. Monica Stival e ao professor Dr. Luiz Repa, pela discussão e pelas sugestões no exame de qualificações.

À Maria Imaculada e ao Luiz Murilo, pelo incentivo e pela cordialidade de sempre.

Aos meus pais, Adriana e Eduardo; e as minhas irmãs, Nathalia e Maria Eduarda, que sempre me apoiaram e que, mesmo de longe, estiveram comigo.

À galera do mal que só tem gente boa: Bruno Rigonato, Thiago Pitaluga, Pedro Marques, Bruno Abdala, Thiago Dantas e Aida Tedesco.

Ao meu amigo (que eu também chamo de avô) Hélio, por tudo que não cabe nesta página.

À Paula, que me reconfortou nos momentos de desânimo e me tranquilizou nos momentos de desespero. Este trabalho não teria sido possível sem que tivéssemos caminhado juntos. Agradeço, profundamente, pela amizade, pela paciência, pelas conversas, pela revisão mas, principalmente, pelo carinho que torna meus dias mais felizes e por sempre me instigar a sair das zonas de conforto.

À Fundação de Amparo à Pesquisa do Estado de São Paulo (FAPESP), pelas bolsas no país e no exterior. 
" N'importe qui parle', mais ce qu'il dit, il ne le dit pas de n'importe où. Il est pris nécessairement dans le jeu d'une extériorité".

Michel Foucault, L'archéologie du savoir

"Mon livre [Les mots et les choses] est une pure et simple fiction: c'est un roman, mais ce n'est pas moi qui l'ai inventé, c'est le rapport de notre époque et de sa configuration épistémologique à toute cette masse d'énoncés. Si bien que le sujet est en effet présent dans la totalité du livre, mais il est le 'on' anonyme qui parle aujourd'hui dans tout ce qui se dit".

Michel Foucault, Dits et écrits I, 48, "Sur les façons d'écrire l'histoire" 


\section{Resumo}

Se é possível dizer que As palavras e as coisas de Michel Foucault realiza um diagnóstico do presente, pensamos que este consiste na descrição arqueológica do modo de coexistência da figura epistemológica do homem com um questionamento sobre o "ser da linguagem" em meados do século XX. O propósito geral desta dissertação será, assim, acompanhar a maneira pela qual Foucault descreve a constituição dos termos desse diagnóstico, a fim de ver como eles chegam a coexistir num mesmo campo epistemológico; mas, também, procuraremos mostrar como essa descrição da coexistência do homem e da linguagem se direciona para isto que consideramos como um ponto de tensão, em que Foucault identifica uma abertura de possibilidades no cerne do saber moderno.

Palavras-chaves: Michel Foucault; arqueologia; ser da linguagem; antropologia. 


\begin{abstract}
If it is possible to say that Michel Foucault's The order of things makes a diagnosis of the present, we think that it consists of the archaeological description of how the epistemological figure of men coexists with a questioning about "the being of language" in the middle of the XX century. Therefore we aim to follow the way Foucault describes the constitution of the terms of this diagnostic, in order to see how they come to coexist in the same epistemological field. Nevertheless we seek to show as well how this description of the coexistence of man and language leads to what we consider a point of tension, in which Foucault identifies a opening up of possibilities at the very heart of the modern thought.
\end{abstract}

Keywords: Michel Foucault; archaeology; being of language; anthropology. 


\title{
Lista de abreviações
}

\author{
AS - L'archéologie du savoir \\ DE I - Dits et écrits I \\ $\mathrm{MC}$ - Les mots et les choses \\ $\mathrm{NC}$ - La naissance de la clinique
}




\section{Sumário}

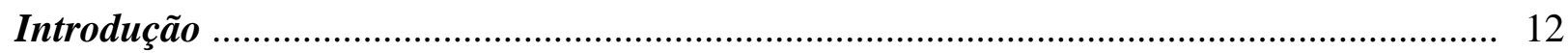

Capítulo 1 - Discurso, representação, "Mathesis qualitativa”, representação, Discurso ......... 21

1. A perspectiva arqueológica sobre o saber clássico e a concepção de uma "mathesis

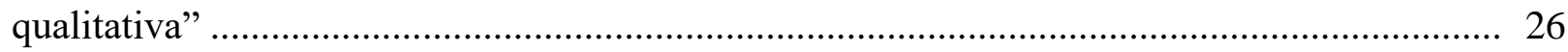

2. Representação e Discurso: a relação da linguagem com o conhecimento das ordens

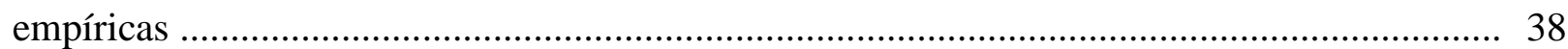

2.1. A teoria clássica dos signos e o "primado da representação" ......................................... 40

2.2 A dissolução da linguagem em um "puro funcionamento": o Discurso .......................... 53

3. A unidade do modo de ser da linguagem clássica ........................................................... 63

Capítulo 2 - A coexistência do homem com a linguagem no saber moderno ........................ 68 1. A projeção do homem no saber moderno como "figura da finitude": a constituição do

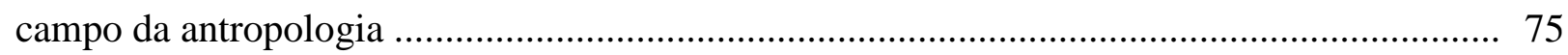

2. O século XX e o enigma do "ser da linguagem" ......................................................... 88

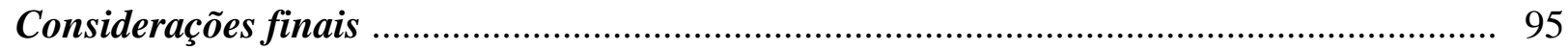

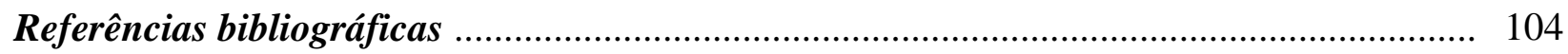




\section{Introdução}

Que o que eu faço tenha alguma coisa a ver com a filosofia é bem possível, sobretudo na medida em que, ao menos desde Nietzsche, a filosofia tem por tarefa diagnosticar e não procura mais dizer uma verdade que possa valer para todos e para todos os tempos. Eu procuro diagnosticar, realizar um diagnóstico do presente: dizer o que nós somos hoje e o que significa, hoje, dizer o que nós dizemos. (DE I, 50, p. 634)

Diante desta declaração de Foucault, feita em uma entrevista de 1967, um ano após a publicação de As palavras e as coisas, não podemos deixar de perguntar: qual é o “diagnóstico do presente" que esta obra apresenta? Mas, ao mesmo tempo, tal questão nos faz hesitar: seria mesmo legítimo colocar essa questão para uma obra que, à primeira vista, parece ser apenas uma teoria sobre a organização das teorias ao longo de um período relativamente longo - do século XVI aos meados do século XX; que, sem se "aprofundar" na análise das mais diferentes "obras" e sem procurar descobrir o que realmente "quiseram dizer" seus autores, parece subtraí-las ao tempo, à história, para subitamente decretar descontinuidades sem "porquês"; que, através de uma linguagem carregada de metáforas, em sua maior parte, trata de disciplinas normalmente consideradas menores em relação às ciências com alto nível de formalização, como a história natural, a análise das riquezas ou a filologia do século XIX? De que maneira, ao lidar com esse material, esta obra poderia, opondo-se à vocação universalista do discurso filosófico tradicional, realizar a tarefa de "dizer o que nós somos hoje" e, sobretudo, "o que significa, hoje, dizer o que nós dizemos"?

Se pensamos, então, nas obras mais conhecidas que precederam As palavras e as coisas, a possibilidade de esta realizar um diagnóstico do presente parece ainda mais remota. Em História da loucura e em Nascimento da clínica, ao menos ainda se tratava de pensar a relação dos conhecimentos com uma dimensão "não discursiva"; ali ao menos ainda havia algo que, talvez, alguns chamariam de "história". Mas, se por um lado o livro de 1966 pôde parecer bem distante de estar de algum modo comprometido com a práxis, por outro, é curioso que ele tenha sido não só um sucesso de vendas tão logo foi publicado ${ }^{1}$, mas que, divulgado como "a maior revolução desde o

\footnotetext{
${ }^{1}$ Como descreve François Dosse: "Foucault vende como pãezinhos [...]. O acontecimento editorial do ano, a melhor venda do verão é incontestavelmente Les mots et les choses de Michel Foucault. [...] O seu sucesso causou [...] surpresa ao editor Pierre Nora e ao próprio autor, visto que a primeira tiragem foi modesta: 3.500 exemplares, rapidamente esgotados. Colocado à venda em abril de 1966, foi necessário reimprimir 5.000 exemplares em junho, depois 3.000 em julho, mais 3.500 em setembro..." - François
} 
existencialismo" 2 , tenha causado polêmica na cena cultural francesa quando estranhamente enunciava em suas últimas linhas: "o homem é uma invenção da qual a arqueologia do nosso pensamento mostra facilmente a data recente. E talvez o fim próximo"3 (MC, p. 398).

O que se chamou de "a morte do homem" não aparece, portanto, como um acontecimento consumado. Aparece, antes, como o vislumbre de seu "fím próximo", como um movimento de reconfiguração do que a arqueologia descreve como uma disposição antropológica no saber moderno, uma disposição do saber da qual "em grande parte ainda não nos desprendemos" (MC, p. 351). Assim, se por volta do final do século XVIII, o homem sobre o qual fala Foucault surgiu na ordem do saber moderno "como no limite do mar um rosto de areia" (MC, p. 398), podemos nos perguntar o que é a onda que, ao mesmo tempo, foi se formando no meio do mar e que talvez poderá apagá-lo - e dizemos “talvez” porque, como adverte o arqueólogo, tratase aí de um "acontecimento do qual podemos, no máximo, pressentir a possibilidade,

Dosse. História do estruturalismo - I. o campo do signo, 1945/1966. São Paulo: Editora Ensaio, 1993, p. 367.

${ }^{2}$ É assim que Madeleine Chapsal irá se referir a As palavras e as coisas no título do seu artigo publicado no semanário L'Express, de 23-29 de maio de 1966. - Cf. Madeleine Chapsal. "La plus grande révolution depuis l'existentialisme". In: Les mots et les choses de Michel Foucault - regards critiques 1966-1968. Caen: Presses universitaires de Caen, 2009, pp. 59-62.

${ }^{3}$ Esta polêmica começou, sobretudo, com a crítica de Sartre. Dada a notoriedade do filósofo existencialista e o fato de que a sua crítica será lembrada em praticamente todas as entrevistas que Foucault concede na década de 1960, dentro e fora da França, após a publicação de As palavras e as coisas, vale registrá-la aqui. Logo no início de uma entrevista publicada em outubro de 1966, na revista L'Arc, cujo número era dedicado a ele mesmo, Sartre é questionado se, na "atitude da jovem geração", ele via uma "inspiração comum". E o filósofo responde: "Uma tendência dominante, ao menos, pois o fenômeno não é geral, é a recusa da história. O sucesso que fez o último livro de Michel Foucault é característico. O que encontramos em As palavras e as coisas? Não uma 'arqueologia' das ciências humanas. $\mathrm{O}$ arqueólogo é alguém que procura os vestígios de uma civilização desaparecida para tentar reconstruí-la. Ele estuda um estilo que foi concebido e implementado pelos homens. Esse estilo pôde, depois disso, impor-se como uma situação natural, tomar o aspecto de um dado. Ele não deixa de ser o resultado de uma práxis de que o arqueólogo retraça o desenvolvimento.

O que Foucault nos apresenta é, como viu muito bem Kanters, uma geologia: a série de camadas sucessivas que formam nosso solo. Cada uma dessas camadas define as condições de possibilidade de um certo tipo de pensamento que triunfou durante um certo período. Mas Foucault não nos diz o que seria o mais interessante, a saber: como cada pensamento é construído a partir dessas condições, nem como os homens passam de um pensamento a outro. Para isso, seria preciso fazer intervir a práxis, logo, a história, e é precisamente o que ele recusa. Certamente sua perspectiva permanece histórica. Ele distingue as épocas, um antes e um depois. Mas ele substitui o cinema pela lanterna mágica, o movimento por uma sucessão de imobilidades. O sucesso de seu livro prova suficientemente que o aguardávamos. Ora, um pensamento verdadeiramente original não é, jamais, aguardado. Foucault traz para as pessoas aquilo do que elas tinham necessidade: uma síntese eclética em que Robbe-Grillet, o estruturalismo, a linguística, Lacan, Tel Quel são utilizados, um após o outro, para demonstrar a impossibilidade de uma reflexão histórica. Por detrás da história, claro, é o marxismo que é visado. Trata-se de constituir uma ideologia nova, a última barreira que a burguesia pode ainda erguer contra Marx." - Jean-Paul Sartre. "Jean-Paul Sartre répond". In: Les mots et les choses de Michel Foucault - regards critiques 1966-1968. Caen: Presses universitaires de Caen, 2009, pp. 75-76. [Publicado originalmente em L'Arc, 1966, no 30, pp. 8796] 
mas do qual nós não conhecemos por enquanto ainda nem a forma nem a promessa" (MC, p. 398).

A "influência" de Nietzsche sobre o seu trabalho é algo que Foucault nunca escondeu. Objeto de diversos estudos dos comentadores da sua obra, que mostram como essa relação é importante para a compreensão da dita "fase genealógica" da sua trajetória intelectual, é certo, também, que a relação da arqueologia com a genealogia nietzschiana dá o que pensar. "Nietzsche, o filólogo" (MC, p. 316), é uma figura que sempre aparece nas obras da década de 1960, seja em História da loucura, como testemunha da reaparição em plena modernidade de uma experiência trágica da loucura, que já começava a ser silenciada no fim do XVI justamente pelo seu Elogio, seja em Nascimento da clínica, como testemunha da possibilidade de uma nova crítica:

\begin{abstract}
é bem provável que pertençamos a uma época de crítica cuja ausência de uma filosofia primeira nos lembra a cada instante o reino e a fatalidade: época de inteligência que nos mantém irremediavelmente à distância de uma linguagem originária. Para Kant, a possibilidade de uma crítica e sua necessidade estavam ligadas, através de certos conteúdos científicos, ao fato de que há conhecimento. Em nossos dias, elas estão ligadas - e Nietzsche, o filólogo, o testemunha - ao fato de que há linguagem e de que nas inumeráveis palavras pronunciadas pelos homens - sejam elas racionais ou insensatas, demonstrativas ou poéticas - um sentido tomou corpo e nos domina, conduz nossa cegueira, mas espera na obscuridade nossa tomada de consciência para vir à luz e pôr-se a falar. Nós estamos historicamente consagrados à história, à paciente construção de discursos sobre os discursos, à tarefa de ouvir o que já foi dito. (NC, p. xii, grifos meus)
\end{abstract}

Foucault chega mesmo a dizer que foi a dívida que o seu trabalho tem para com Nietzsche que o levou, em As palavras e as coisas, a lhe dar "um estatuto ambíguo, absolutamente privilegiado, meta-histórico"4 (DE I, 48, p. 627). E declara que muito da importância do filósofo alemão consiste em ele já ter mostrado, do recuo de sua época, o que se constituirá como um grande problema para o pensamento na metade do século XX; assim, "se em certos domínios ele permanece um homem do século XIX, ele genialmente antecipou nossa época" (DE I, 41, p. 580). Antes que criemos falsas expectativas no leitor, digamos logo que aqui não iremos tratar mais a fundo da relação dos dois pensadores, mas apenas tomar como ponto de partida um dos motivos que levou Foucault a dar a Nietzsche um lugar privilegiado em sua obra, isto é, um

\footnotetext{
${ }^{4}$ Mas vale notar que, quando Foucault descreve desta maneira, em 1967, o estatuto dado a Nietzsche em As palavras e as coisas, ele demonstra um certo arrependimento de tê-lo feito: "Se eu tivesse que recomeçar esse livro terminado há dois anos, eu tentaria não dar a Nietzsche este estatuto ambíguo, absolutamente privilegiado, meta-histórico, que tive a fraqueza de lhe dar". - (DE I, 48, p. 627). Em todas as referências a essa obra, Dits et écrits I, o número do texto, padronizado em todas as edições, será indicado antes do número da página.
} 
problema que ele "antecipa" já no fim do século XIX. Qual seria este problema? A certa altura de As palavras e as coisas, lemos que, ao longo do século XIX,

\begin{abstract}
a reflexão filosófica se manteve durante muito tempo distanciada da linguagem. Enquanto ela procurava incansavelmente do lado da vida ou do trabalho alguma coisa que fosse seu objeto, ou seus modelos conceituais, ou seu solo real e fundamental, só dava à linguagem uma atenção lateral; tratava-se, para ela, sobretudo de afastar os obstáculos que ela [a linguagem] podia opor a sua tarefa; era preciso, por exemplo, liberar as palavras dos conteúdos silenciosos que as alienava, ou ainda, tornar a linguagem flexível e, do interior, torná-la como que fluida para que, liberada das espacializações do entendimento, ela pudesse restituir o movimento da vida e da sua duração própria. A linguagem só entrou diretamente e por si mesma no campo do pensamento no fim do século XIX. Poder-se-ia mesmo dizer no século XX, se Nietzsche, o filólogo [...], não tivesse sido o primeiro a aproximar a tarefa filosófica de uma reflexão radical sobre a linguagem" (MC, p. 316) (MC, p. 316)
\end{abstract}

No entanto, segundo Foucault, o filósofo alemão não apenas fez a linguagem entrar no campo das preocupações fillosóficas. Na verdade, ao fazê-lo, ele colocava uma questão maior. Pensamos que é a partir dela que podemos começar a nos aproximar do que está em jogo em As palavras e as coisas:

foi ele [Nietzsche] que, através da cultura alemã, compreendeu que a redescoberta da dimensão própria à linguagem é incompatível com o homem. Daí que, para nós, Nietzsche tenha assumido um valor profético. E que, em compensação, seja preciso condenar com a mais completa severidade todas as tentativas de tornar insípido este problema. (DE I, 34, p. 531)

Pautando-nos por essas breves considerações que Foucault faz sobre Nietzsche, vemos então que, além deste definir a "tarefa" da filosofia como "este trabalho de escavação sob nossos pés [que] caracteriza [...] o pensamento contemporâneo" (DE I, xx, p. 634), a sua "genialidade" confere, também, um problema ao pensamento futuro. Levando em conta que Foucault assumiu esta tarefa e não se furtou a este problema, podemos colocar a seguinte questão: não seria possível encontrar o diagnóstico do presente de As palavras e as coisas justamente na maneira como Foucault descreve, no cerne do saber moderno, a relação da figura epistemológica do homem com o "ser da linguagem"? Parece-nos que é descrevendo essa relação que a arqueologia toca de modo mais incisivo o seu presente:

Será nossa tarefa futura a de avançarmos em direção a um modo de pensar, desconhecido até o presente em nossa cultura, e que permitiria refletir ao mesmo tempo, sem descontinuidade nem contradição, o ser do homem e o ser da linguagem? [...] Mas é possível também que esteja para sempre excluído o direito de pensar ao mesmo tempo o ser da linguagem e o ser do homem; é possível que haja aí algo como uma abertura [béance] indelével (aquela na qual justamente nós existimos e nós falamos), de modo que seria preciso rechaçar como quimeras toda antropologia na qual estaria em questão o ser da linguagem, toda concepção da linguagem ou da significação que 
gostaria de reunir-se, manifestar e liberar o ser próprio do homem. É talvez aí que se enraíza a escolha filosófica mais importante de nossa época. Escolha que pode se fazer tão somente no esforço de uma reflexão futura. Pois nada pode nos dizer de antemão de qual lado a via está aberta. (MC, p. 350, grifos meus)

Entretanto, diante dessas possibilidades dadas, sobre cujo desfecho a arqueologia nada diz, Foucault logo em seguida acrescenta: "a única coisa que sabemos por enquanto com toda certeza é que jamais na cultura ocidental o ser do homem e o ser da linguagem puderam coexistir $e$ se articular um com o outro. Sua incompatibilidade foi um dos traços fundamentais do nosso pensamento" (MC, p. 350, grifo meu). Assim, ao dizer que essa incompatibilidade é a única certeza que a arqueologia pode ter a respeito da relação entre o homem e a linguagem, é certo também que, ao mesmo tempo, Foucault está apontando para o fato de que eles coexistem no saber moderno. Afinal, é esta coexistência que dá ensejo para que se possa perguntar sobre a possibilidade ou impossibilidade da articulação de um com outro. Em vista disso, sobre o fundo de tal incompatibilidade, o centro desse diagnóstico, com efeito, parece consistir na descrição arqueológica do modo de coexistência da figura epistemológica do homem com um questionamento sobre o "ser da linguagem" em meados do século XX. O propósito geral desta dissertação será, portanto, acompanhar a maneira pela qual Foucault descreve a constituição dos termos desse diagnóstico, a fim de ver como eles chegam a coexistir num mesmo campo epistemológico; mas, também, procuraremos mostrar como essa descrição da coexistência do homem e da linguagem se direciona para isto que consideramos como um ponto de tensão, no qual Foucault identifica uma abertura de possibilidades no cerne do saber moderno.

Esta espécie de prudência que Foucault mantém ao ressaltar que, diante da coexistência do homem e da linguagem, "nada pode nos dizer de antemão de qual lado a via está aberta", pode nos levar a pensar que o diagnóstico do presente de As palavras e as coisas será marcado por um tom de imparcialidade. Esta impressão, no entanto, logo se desfaz se lembrarmos que, em larga medida, Foucault realiza esse diagnóstico motivado por algo que marcou profundamente a sua trajetória intelectual dos anos 1960, a saber, a crítica ao que ele chama de antropologia. Para começarmos, então, a compreender um pouco melhor os termos que estão em jogo no diagnóstico, fiquemos, por ora, com uma explicação esquemática do que o filósofo entende por antropologia dada numa entrevista concedida em 1965 a Alain Badiou: 
antropologia, eu entendo esta estrutura propriamente filosófica que faz com que agora os problemas da filosofia estejam todos alojados no interior deste domínio que se pode chamar de finitude humana. (DE I, p. 467).

A tarefa de realizar uma crítica à antropologia pressupõe, portanto, que tal domínio no qual se alojam os problemas da filosofia moderna seja determinado. Não é por outra razão que grande parte do trabalho de Foucault em As palavras e as coisas consistiu em descrever como se formou, no saber moderno, o domínio da finitude humana, ou, para dizê-lo diretamente, a figura epistemológica do homem.

Embora o seu alvo seja essa "estrutura propriamente filosófica", tal crítica não se baseia numa análise que pressupõe uma pretensa autonomia do discurso filosófico ${ }^{5}$. Se é a finitude humana que constitui o domínio dos problemas da filosofia - ou melhor, de um certo tipo de reflexão filosófica que Foucault jamais pretendeu que esgotasse a filosofia moderna - é do exterior desta que a sua crítica parte: para descrever, em $A s$ palavras e as coisas, a formação desse domínio do saber moderno, a fim de mostrar o autoesgotamento da reflexão que se desenvolve no seu interior, a maior parte das análises arqueológicas privilegia os saberes empíricos. Daí que a organização geral da obra se centre em três eixos, a saber, nas análises dos saberes que tratam das relações econômicas, dos seres vivos e das palavras. Será a partir dos conteúdos empíricos desses saberes que, na modernidade, a figura do homem poderá se projetar, pela primeira vez, no saber e se constituir como um domínio no interior do qual os problemas da filosofia se desdobram e com o qual as ciências humanas do fim do século XIX e início do século XX se articulam de um modo peculiar ${ }^{6}$.

Com efeito, aí se encontra um dos lances maiores da obra de Foucault, ou seja, o de desnaturalizar a ideia de que o homem desde sempre se prestou ao conhecimento, seja pela reflexão que o visa como sujeito que conhece, seja como objeto de uma

\footnotetext{
${ }^{5} \mathrm{O}$ esboço dessa crítica já aparece na Introdução à Antropologia, texto de 1961 que compõe a sua tese secundária de doutoramento, junto com uma tradução do escrito de Kant intitulado Antropologia de um ponto de vista pragmático. Em 1964, Foucault publicará somente a tradução e no lugar da Introdução aparecerá uma breve Notice historique, ao fim da qual, numa nota, o filósofo já faz a seguinte menção à As palavras e as coisas: "as relações do pensamento crítico e da reflexão antropológica serão estudadas numa obra ulterior" (DE I, 19, p. 321, n. 1). Com a publicação póstuma da Introdução, pôde-se ver que aí já se apresentavam alguns aspectos que irão compor a figura epistemológica do homem na obra de 1966; no entanto, nesta obra, a crítica à antropologia é elaborada a partir de uma estratégia bem diversa e, com efeito, bem mais complexa. Como dizem os editores da Introdução, em As palavras e as coisas, "foi em uma configuração recente do saber - saber da produção, do vivente e das línguas - e não no destino da filosofia moderna que, doravante, ele situava a emergência e a provável desaparição da figura do homem que apareceu no século XVIII como duplo empírico-transcendental." - Daniel Defert, François Ewald, Frédéric Gros. "Presentation". In: Michel Foucault; Immanuel Kant. Anthropologie du point de vue pragmatique \& Introduction à l'Antropologie. Paris : Vrin, 2009, p. 9.

${ }^{6}$ Vale notar desde já que a análise desta articulação extrapola os limites do "recorte" deste trabalho.
} 
ciência possível. Mas se, por um lado, a arqueologia mostra que a figura epistemológica do homem é tributária dos saberes empíricos modernos, por outro, a novidade dessa figura é reforçada por uma relativização epocal que se baseia principalmente na explicitação da ordem do saber na idade clássica (que se estende da primeira metade do século XVII ao fim do século XVIII). Deste modo, descrevendo as diferenças que instauram uma descontinuidade entre duas ordens do saber, Foucault pôde destacar, por comparação e contraste, a modernidade da figura do homem, apontando para sua ausência no saber clássico. A despeito de facilmente reconhecermos nesta época o esforço de definição da "natureza humana", a arqueologia insiste que "não havia aí consciência epistemológica do homem como tal” (MC, p. 320)

\begin{abstract}
No pensamento clássico, aquele para quem a representação existe, e que se representa a si mesmo nela, reconhecendo-se aí por imagem ou reflexo, aquele que amarra todos os fios entrecruzados da 'representação em quadro', - esse jamais se encontra aí presente. Antes do fim do século XVIII, o homem não existia. Não mais que a potência da vida, a fecundidade do trabalho, ou a espessura histórica da linguagem. É uma criatura muito recente, que a demiurgia do saber fabricou com as suas próprias mãos há menos de duas centenas de anos: mas ele envelheceu tão rápido que imaginamos facilmente que ele tinha esperado na sombra durante milênios o momento em que ele seria enfim conhecido. (MC, p. 319)
\end{abstract}

Colocando assim a presença do homem no saber moderno face a face com sua ausência no saber clássico, Foucault procura causar estranhamento ao falar que, neste último, as ligações das representações se dão sem aquele que as opera. Mas esta ausência, na verdade, indica-nos a necessidade de voltar para as análises do saber clássico, a fim de trazer à baila um terceiro termo que exerce uma função importante na elaboração desse diagnóstico. Essas análises seguem o preceito de evitar toda visão retrospectiva sobre o saber clássico, pela qual "deformamo-lo, mascaramo-lo através de categorias ou um recorte que são nossos” (MC, p. 86). Um tipo de visão que acaba ignorando a especificidade desse saber, na medida em que tende a identificar nele figuras epistemológicas próprias do saber moderno, a fim de encontrar a sua gênese. Neste sentido, é comum pensarmos que, sob uma noção como a de "natureza humana", esteja salvaguardada uma entidade perene, "o homem"; porém, a arqueologia desse saber nos mostra que,

no ponto de encontro entre a representação e o ser, aí onde se entrecruzam natureza e natureza humana, neste lugar em que hoje acreditamos reconhecer a existência primeira, irrecusável e enigmática do homem - o que o pensamento clássico faz surgir é o poder do discurso. Ou seja, da linguagem enquanto ela representa - a linguagem que nomeia, que recorta, que combina, que ata e desata as coisas, tornando-as visíveis na transparência das palavras. (MC, pp. 321-322, grifos meus) 
No entanto, para não confundirmos os termos que se articulam na elaboração do diagnóstico do presente de As palavras e as coisas, é preciso nos esquivar, desde já, de alguns equívocos que, todavia, podem surgir dessa afirmação de Foucault - segundo a qual, no saber clássico, onde se acreditou encontrar o homem, o que havia, na verdade, era a linguagem. Primeiro, essa afirmação poderia nos levar a pensar que, se no centro do diagnóstico está o modo de coexistência do homem e da linguagem, a tensão que a caracteriza seria então provocada simplesmente pela aparição do homem no fím do século XVIII, colocando em xeque essa posição privilegiada na qual a linguagem se manteve ao longo da idade clássica. Em suma, tratar-se-ia de uma tensão entre o modo de ser da linguagem clássica e a figura moderna do homem. O que, além disso, implicaria que, com a passagem da ordem do saber clássico à ordem do saber moderno, esse modo de ser da linguagem se manteria inalterado a despeito de todas as diferenças que existem entre essas duas ordens; e, assim, incorreríamos novamente nas distorções de uma visão retrospectiva que identifica continuidades onde a arqueologia descreve descontinuidades.

Mas, como veremos, nem isto nem aquilo é o caso. Nesse diagnóstico, não se tratará de uma relação da figura epistemológica do homem com um modo de ser da linguagem que se subtrairia à historicidade do saber. Descrevendo o saber clássico, Foucault é meticuloso ao mostrar que aí a linguagem adquire um modo de ser muito particular: aí, a linguagem é Discurso ${ }^{7}$.

Nesse sentido, a arqueologia de As palavras e as coisas pode ser compreendida também como uma teorização do modo de ser da linguagem próprio a cada uma das épocas analisadas. Philippe Sabot notou isso:

O conjunto do desenvolvimento de Palavras e as coisas se prende, com efeito, a mostrar como as diferentes configurações epistemológicas do saber que dão lugar a regimes de discursividade e de cientificidade distintos na Renascença, na idade clássica e na modernidade erguem-se, cada uma, em última instância, de um certo modo de ser da linguagem que Foucault se põe a identificar. ${ }^{8}$

Embora Sabot não desenvolva esta ideia ao longo do seu comentário, ele é preciso quando aponta que na base da configuração epistemológica de cada época se encontra um determinado modo de ser da linguagem; o que se mostra de modo claro no

\footnotetext{
${ }^{7}$ Embora, ao longo de As palavras e as coisas, "discurso" apareça, na maioria das vezes, com a inicial minúscula, utilizaremos esse termo com a inicial maiúscula para designar o modo de ser da linguagem clássica. Isto para diferencia-lo do "discurso" ou dos "discursos" tomados na acepção metodológica de material analisado pela arqueologia.

${ }^{8}$ Philippe Sabot. Lire Les mots et les choses de Michel Foucault. Paris: PUF, 2006, p. 7.
} 
papel que o Discurso desempenha no saber clássico. Todavia, o interesse de Foucault pelo saber clássico não parece se limitar ao propósito de fazer aparecer a sua especificidade, mas que possui um alcance maior no conjunto da obra: mais do que um fím em si mesma, a descrição do saber clássico e, particularmente, do papel aí desempenhado pelo Discurso compõe o seu diagnóstico do presente. François Châtelet observou que "nascem [de As palavras e as coisas] um olhar radicalmente novo sobre o passado da cultura ocidental e uma concepção mais lúcida da confusão do seu presente" ${ }^{9}$. Ora, parece-nos que justamente essa espécie de ontologia histórica da linguagem constitui a via pela qual essa perspectiva sobre o passado pode vir a se articular com um diagnóstico do presente.

Procuraremos então mostrar, no primeiro capítulo, o que é o Discurso e qual é o seu papel no saber clássico, pois assim poderemos ver, no segundo capítulo, como ele consiste num terceiro termo indispensável para o diagnóstico que As palavras e as coisas realiza; pois é em relação a ele, ou, antes, à falta dele no saber moderno, que a coexistência do homem e do modo de ser moderno da linguagem ganha o seu relevo.

\footnotetext{
${ }^{9}$ François Châtelet, "L’homme, ce Narcisse incertain”. In: Les mots et les choses de Michel Foucaultregards critiques 1966-1968. Caen: Presses universitaires de Caen, 2009, p. 52.
} 


\section{Capítulo 1 \\ Discurso, representação, “Mathesis qualitativa", representação, Discurso}

Desde o prefácio, Foucault chama a atenção para um aspecto importante da sua obra, ou seja, para a centralidade das análises do domínio empírico do saber em meio a tantas outras que as orbitam e que versam sobre a "reflexão" filosófica, bem como sobre a literatura e a história, e mesmo sobre As meninas de Velásquez. As palavras e as coisas: "neste relato, o que deve aparecer são, no espaço do saber, as configurações que deram lugar às formas diversas do conhecimento empírico" (MC, p. 13, grifo meu). A obra irá, pois, organizar-se em torno de três eixos, isto é, em torno das análises dos saberes que tratam das relações econômicas, dos seres vivos e das palavras. No entanto, "não se tratará [...] de conhecimentos descritos em seus progressos em direção a uma objetividade na qual nossa ciência de hoje poderia enfim se reconhecer" (MC, p. 13); e Foucault continua, enunciando da seguinte maneira o propósito que o anima:

o que gostaríamos de trazer à luz é o campo epistemológico, a epistémê $\hat{e}^{10} \mathrm{em}$ que os conhecimentos, encarados fora de qualquer critério referente a seu valor racional ou a suas formas objetivas, enraízam sua positividade e manifestam assim uma história que não é a de sua perfeição crescente, mas, antes, a de suas condições de possibilidade. (MC, p. 13)

Trata-se então de empreender, por meio de uma análise dos discursos, um trabalho histórico, mas que, segundo Foucault, diferencia-se da maneira tradicional de fazer história (tanto da história tout court, quanto das histórias das ciências e das ideias) (cf. MC, p. 13). Assim, ele descreverá o campo epistemológico em que, durante a idade clássica, puderam se formar a gramática geral, a história natural e a análise das riquezas; isto, entretanto, para mostrar, logo em seguida, as transformações das "configurações" do saber que, por volta do início do século XIX, levaram ao desaparecimento dessas disciplinas e que tornaram possível a formação da filologia, da biologia e da economia política. Neste sentido, a descrição dessas transformações mostra como elas instauraram uma descontinuidade entre duas ordens distintas do saber, isto é, uma descontinuidade que separa, por um lado, a ordem do saber clássico e, por outro, a ordem do saber moderno. Logo, a arqueologia descreve as transformações e a descontinuidade entre dois campos epistemológicos que, ao longo de um período da história do saber,

\footnotetext{
${ }^{10}$ A fim de seguir de perto a predominância da referência ao espaço, entendido como o "espaço do saber", ao qual se dirige a descrição arqueológica de As palavras e as coisas, utilizaremos, ao longo deste trabalho, a noção de "campo epistemológico" ao invés da noção de epistémê.
} 
mantiveram uma organização estável, como "sistemas de simultaneidade". Quer dizer, sistemas constituídos pelos "isomorfismos entre os conhecimentos" "11 (DE I, p. 571) de disciplinas diversas que, à primeira vista, podem não mostrar que mantêm relações entre si, ainda que estas últimas não sejam "secretas, ocultas, mais silenciosas ou mais profundas que a consciência dos homens" (DE I, 66, p. 800): “eu tentei [...]” diz Foucault, "definir relações que estão na superfície mesma dos discursos; eu tentei tornar visível o que só é invisível por estar muito na superfície das coisas”. Para o arqueólogo, este é o caso das relações entre as disciplinas empíricas que sua descrição do saber clássico buscou mostrar. Como ele afirma:

\begin{abstract}
ao nível arqueológico, vê-se que o sistema das positividades mudou de maneira massiva na virada dos séculos XVIII e XIX. Não que a razão tenha feito progressos, mas o modo de ser das coisas e da ordem que, distribuindoas, oferece-as ao saber, é que foi profundamente alterado. Se a história natural de Tournefort, de Linné e de Buffon tem relação com outra coisa que não ela mesma, não é com a biologia, com a anatomia comparada de Cuvier ou com o evolucionismo de Darwin; é com a gramática geral de Bauzée, a análise da moeda e da riqueza tal como a encontramos em Law, em Véron de Fortbonnais ou em Turgot. Os conhecimentos chegam talvez a se engendrar, as ideias a se transformar e a agir umas sobre as outras (mas como? Os historiadores até o presente não no-lo disseram); uma coisa, em todo caso, é certa: a arqueologia, dirigindo-se ao espaço geral do saber, a suas configurações e ao modo de ser das coisas que aí aparecem, define sistemas de simultaneidade, assim como a série de mutações necessárias e suficientes para circunscrever o limiar de uma positividade nova. (MC, p. 14, grifos meus)
\end{abstract}

Ora, quando Foucault escolhe voltar a atenção para o saber clássico, não para procurar restituir os liames e a continuidade que poderia haver entre a gramática geral e a filologia, entre a história natural e a biologia e entre a análise das riquezas e a

\footnotetext{
${ }^{11}$ É interessante o que Foucault diz nesta mesma entrevista, a respeito do vínculo deste tipo de análise "arqueológica" (ainda que ele não a nomeie) com um "pensamento não dialético" - o que se mostra também, como veremos Foucault dizer logo adiante, no fato de que a arqueologia não é uma história que se propõe a desvelar os desenvolvimentos progressivos da razão: "É preciso tentar descobrir a forma própria e absolutamente contemporânea deste pensamento não dialético. A razão analítica do século XVII se caracterizava essencialmente por sua referência à natureza, a razão dialética do século XIX desenvolveu-se sobretudo em referência à existência, ou seja, ao problema das relações do individuo à sociedade, da consciência à história, da práxis à vida, do sentido ao não-sentido, do vivente ao inerte.

Parece-me que o pensamento não dialético que se constitui agora não coloca em jogo a natureza ou a existência, mas o que é o saber. Seu objeto próprio será o saber, de tal sorte que este pensamento estará numa posição segunda em relação ao conjunto, à rede geral dos nossos conhecimentos. Ele terá que se interrogar sobre a relação que pode haver, de um lado, entre os diferentes domínios do saber e, de outra parte, entre saber e não-saber." - (DE I, 39, p. 571)

Ainda que Foucault aponte esta tarefa como algo que ainda deverá ser realizada, a arqueologia de $A s$ palavras e as coisas, com efeito, dedicou-se à primeira dessas interrogações, a descrever as relações entre diferentes domínios do saber. E, para Foucault, este tipo de análise/descrição que ele realiza já seria uma contraposição ao tipo de reflexão antropológica que ele crítica em sua obra. Ele termina a sua resposta dizendo: "é menos sedutor falar do saber e dos seus isomorfismos do que da existência e do seu destino, menos consolador falar das relações entre saber e não-saber do que falar da reconciliação do homem consigo mesmo numa iluminação total. Mas, afinal, o papel da filosofia não é necessariamente aliviar a existência dos homens e de lhes prometer alguma coisa como uma felicidade" - (DE I, 39, p. 571).
} 
economia política, mas para descrever a formação arqueológica das primeiras e, relacionando-as, mostrar que, juntas, elas formam um "sistema de simultaneidade": qual seria o interesse dessa escolha para o que ele tem a dizer sobre a sua época? Ao descrever minuciosamente o sistema dessas "positividades", e, também, as transformações que farão com que, no fim do século XVIII, ele desapareça e torne possível uma nova sistematicidade do domínio empírico no saber moderno: qual seria a importância disso para a elaboração do diagnóstico do presente de As palavras e as coisas?

São essas questões que se encontram no horizonte de tudo o que veremos ao longo deste capítulo e que servem de critério para que, diante da extensa análise que Foucault faz do saber clássico, selecionemos algumas das suas características fundamentais e deixemos de lado outras tantas. Certamente, estas são questões bastante gerais e, para que o leitor possa se situar no que se segue, é necessário que façamos aqui, logo de saída, ao menos algumas indicações de resposta.

Quando Foucault volta a sua atenção para o saber clássico e, dentre tantas ciências que existiram neste período, escolhe fazer uma descrição da formação arqueológica da gramática geral, da história natural e da análise das riquezas para mostrar que esse domínio empírico é dotado de uma sistematicidade rigorosa, parecenos que esta escolha não é nem um pouco desinteressada quanto ao que ele tem a dizer sobre a sua época. Mas qual seria o ponto a partir do qual poderíamos apreender este interesse?

Como dissemos na "Introdução", pensamos que, se As palavras e as coisas apresenta um diagnóstico do presente, este consiste na descrição do modo de coexistência, no saber moderno, da figura epistemológica do homem com um questionamento sobre o "ser da linguagem"; quer dizer, na descrição de como a coexistência do homem com a linguagem representa uma tensão no cerne do saber moderno e, especialmente, em meados do século XX. Nas últimas páginas de $A s$ palavras e as coisas, Foucault designa esta tensão da seguinte maneira: "neste ponto em que a questão da linguagem ressurge $\mathrm{e}^{12}$ com uma tão forte sobredeterminação e em que ela parece acometer [investir] por todas as partes a figura do homem [...], a cultura contemporânea trabalha numa parte importante do seu presente e talvez do seu futuro" (MC, p. 394). Com isso em mente, se visamos as suas análises do saber clássico,

\footnotetext{
${ }^{12}$ As razões pelas quais Foucault fala de um resurgimento da questão da linguagem é algo que veremos na última seção do capítulo 2 desta dissertação.
} 
procurando encontrar os elementos que também entram na elaboração deste diagnóstico, a sua escolha por privilegiar aquelas três disciplinas empíricas se revela estratégica, pois as transformações que se dão, no fim do século XVIII, neste domínio empírico consistem nas condições necessárias tanto para o surgimento do homem, quanto para o ressurgimento da questão da linguagem no saber moderno. Ou seja, o despontar, na ordem do saber, dos termos que estão em jogo no diagnóstico do presente de $A s$ palavras e as coisas tornou-se possível somente a partir das transformações que levaram ao desaparecimento do sistema daquelas disciplinas.

Acompanharemos como Foucault descreve o surgimento desses termos no segundo capítulo desta dissertação, pois, se para que eles pudessem surgir foi necessário o desaparecimento do sistema das empiricidade clássicas, devemos, antes, perguntar: o que faz com que elas possuam essa organização sistemática? Dito de outro modo, o que faz com que a figura epistemológica do homem e um questionamento sobre o "ser da linguagem" não possam existir no saber clássico? Para Foucault, ainda que a sua demonstração seja complexa, a resposta para essas questões é simples: trata-se do Discurso. Por um lado, como ele diz claramente: “o homem só existiu desde o começo do século XIX porque o discurso cessou de ter força de organização sobre o mundo empírico." (DE I, [34], p. 529, cf. MC, p. 394); e, por outro lado, uma vez que o Discurso consiste no modo de ser da linguagem clássica, o seu desaparecimento, consequentemente, poderá dar lugar a um novo modo de ser da linguagem, sobre o qual o saber moderno fará proliferar uma série de indagações.

Assim, procuraremos mostrar neste primeiro capítulo o que significa dizer que a linguagem clássica se define como Discurso e porque Foucault lhe atribui essa "força de organização sobre o mundo empírico", já que será sobre o fundo do seu desaparecimento que os termos do diagnóstico do presente de As palavras e as coisas ganharão o relevo que lhes é próprio. Pode-se dizer, então, que o ponto que nos permite apreender o interesse das análises arqueológicas do saber clássico para a elaboração de um diagnóstico do presente consiste nessa espécie de ontologia da linguagem clássica que Foucault realiza. E, como vimos na "Introdução", esse diagnóstico não é imparcial. Em As palavras e as coisas, ele parece arrematar a crítica ao tipo de reflexão que se tornou possível com o surgimento da figura epistemológica do homem no saber moderno. Neste sentido, essa ontologia da linguagem clássica certamente também constitui um elemento importante para esta crítica à antropologia. Pois, se um dos aspectos dessa crítica consiste em mostrar que "o homem não é o mais velho problema 
nem o mais constante que se tenha colocado ao saber humano" (MC, p. 398), mas uma figura relativamente recente que só pôde surgir com o desaparecimento do Discurso; essa ontologia, além de permitir mostrar a sua data de nascimento, vem reforçar o caráter efêmero dessa figura. Isto é o que podemos ver através de uma, dentre as tantas questões que Foucault deixa em aberto, dessas questões-limite que ele deixa a entender que são as mais prementes para a sua época: "não seria preciso admitir que, estando a linguagem novamente aí, o homem retornará àquela inexistência serena em que outrora o mantivera a unidade imperiosa do Discurso?" (MC, p. 397).

Vemos, portanto, que uma articulação entre o diagnóstico do presente e a crítica à antropologia passa, em As palavras e as coisas, por essa espécie de ontologia histórica da linguagem pela qual Foucault descreve os seus modos de ser em cada uma das épocas de que ele trata. Como afirma José Ternes: "poderíamos, sem dúvida, traçar duas linhas que perpassam todo o texto de [As palavras e as coisas]. Uma diz respeito ao conhecimento (saber). A outra, à linguagem" ${ }^{13}$. Assim, procuraremos mostrar o interesse das análises do saber clássico para a elaboração de um diagnóstico do presente, tendo em vista que, nesta época, aquelas duas linhas, como acrescenta Ternes, "se estreitam, sobrepõem-se, fundem-se, na medida em que tudo se passa no universo das ideias, e a própria linguagem já [...] é, ela própria, pensamento." ${ }^{\text {E }}$ Esse interesse parece poder vir à luz, sobretudo, se voltarmos a atenção para dois traços maiores que caracterizam o modo de ser da linguagem clássica: o papel que ela desempenha no saber ou o seu caráter instrumental, que provém de sua fusão com a representação e com o conhecimento, definindo-a como Discurso; e a sua unidade, através da qual a arqueologia mostra o que faz com que o domínio da gramática geral, da história natural e da análise das riquezas possua uma sistematicidade própria no interior do saber clássico.

De um modo geral, será sobre essas duas características da linguagem clássica que tratarão, respectivamente, a segunda e terceira seções deste capítulo. Antes, porém, na primeira seção, a fim de que possamos nos situar na perspectiva da análise arqueológica, veremos como, para Foucault, essas disciplinas empíricas se formaram em relação a uma regra geral do saber clássico, isto é, em relação a uma mathesis; e, particularmente, por que elas constituem, na disposição geral deste saber, o domínio de

\footnotetext{
${ }^{13}$ José Ternes. Michel Foucault e a idade do homem. Goiânia: Editora da UFG, Editora da UCG, $2^{\text {a }}$ edição, 2009, p. 86.

${ }^{14}$ Idem, p. 86.
} 
uma "mathesis qualitativa", que é justamente o domínio em que o Discurso irá "funcionar" ligado à representação e aos conhecimentos.

\title{
1. A perspectiva arqueológica sobre o saber clássico e a concepção de uma "mathesis qualitativa"
}

Se formos ao "Prefácio à edição inglesa" de As palavras e as coisas, veremos que a maneira como Foucault apresenta o que foi a sua "hipótese de partida" (DE I, 72, p. 876) também indica o caráter central que as análises do domínio empírico do saber possuem nesta obra:

\begin{abstract}
e se o saber empírico, numa época e numa cultura dadas, possuíssem efetivamente uma regularidade bem definida? Se a possibilidade mesma de registrar fatos, de se deixar convencer por eles, de os contorcer [gauchir] em tradições ou de fazer deles um uso puramente especulativo, se mesmo isso não estivesse submetido ao acaso? Se os erros (e as verdades), a prática das velhas crenças - entre as quais contam não somente as verdadeiras descobertas, mas também as ideias mais ingênuas -, se tudo isso obedecesse, num momento dado, às leis de um certo código de saber? Se, em suma, a história do saber não formalizado possuísse ela mesma um sistema? Tal foi [...] o primeiro risco que eu assumi. (DE I, 72, pp. 875-876)
\end{abstract}

Trata-se de uma "hipótese" polêmica, pois ela mostra que As palavras e as coisas também se insere num debate com os trabalhos de história das ciências, sobretudo com os que foram realizados na França. Esse debate aparece explicitamente em muitos momentos do seu livro e toca diversas questões, embora Foucault nunca nomeie os autores e as obras com os quais ele está discutindo. Não é o nosso propósito aqui entrar nos meandros dessa discussão e sugerir quais seriam esses autores e essas obras, uma vez que isso poderia constituir, por si só, o objeto de um outro estudo. Todavia, para que possamos nos situar na perspectiva da análise arqueológica do saber clássico, parece-nos interessante começar destacando um ponto de divergência que está em jogo já nesta aposta inicial de Foucault de que haveria uma regularidade nos saberes empíricos não formalizados. Ou seja, ao fazer essa aposta, Foucault coloca em questão certa hierarquia das ciências que lhe parece atuar na escolha que aqueles trabalhos fazem dos seus objetos. A título de contextualização, vejamos como ele mesmo apresenta essa hierarquia:

na França, ao menos, a história da ciência e do pensamento dá lugar às matemáticas, à cosmologia e à física - ciências nobres, ciências rigorosas, ciências do necessário, todas próximas da filosofia: pode-se ler, na sua 
história, a emergência quase ininterrupta da verdade e da razão pura. Mas, considera-se as outras disciplinas - aquelas, por exemplo, que concernem aos seres vivos, às línguas ou aos fatos econômicos - como tingidas demais de pensamento empírico, expostas demais aos caprichos do acaso ou das figuras da retórica, às tradições seculares e aos acontecimentos exteriores, para que se suponha nelas uma outra história que não seja irregular. Espera-se delas, no máximo, que deem testemunho de um estado de espírito, de um modo intelectual, de uma mistura de arcaísmo e de estimativa [supputation] ousada, de intuição e de cegueira. (DE I, 72, p. 876)

Essa avaliação que, segundo Foucault, as histórias das ciências fazem sobre os conhecimentos empíricos das palavras, dos seres vivos e dos fatos econômico exclui, portanto, logo de saída, a possibilidade de que a sua história mostre que eles possuem algum tipo de regularidade. Assim, tendo em mente aquela aposta inicial de Foucault, quando nos voltamos para as suas análises do saber clássico, não surpreende que, contrapondo-se a essa avaliação, ele se incline, desde o início, na direção de mostrar como os conhecimentos da gramática geral, da história natural e da análise das riquezas podem pertencer ao campo epistemológico dessa época. Ou seja, não surpreende que as análises do saber clássico comecem mostrando que, tanto essas disciplinas empíricas que As palavras e as coisas privilegiará, quanto outros saberes que aí são apenas mencionados (como, por exemplo, a astronomia, a física e as matemáticas), formaramse nesse campo segundo uma "regularidade" arqueológica.

Será, pois, pela descrição do que se pode considerar como a disposição basilar do conjunto do saber clássico que Foucault poderá requerer o igual pertencimento de todos esses saberes ao campo epistemológico dessa época. Noutras palavras, tratar-se-á de mostrar que a formação de todos eles se faz, antes de tudo, em relação a uma regra arqueológica geral do saber clássico, isto é, em relação a uma mathesis, a uma ciência geral da ordem e da medida. Como diz Foucault, neste saber, "as ciências trazem sempre consigo o projeto, mesmo longínquo, de um ordenamento exaustivo: elas também sempre apontam para descoberta dos elementos simples e da sua composição progressiva" (MC, p. 89).

Como Foucault chega a definir essa relação com a mathesis como uma regra arqueológica que se estende ao conjunto do saber clássico? Tal questão nos coloca mais uma vez frente a um embate do arqueólogo com as histórias das ciências e das ideias, mas que, neste caso, confronta a caracterização geral do saber clássico que elas elaboram. Pois, visando descrever a "regularidade" de "um campo relativamente negligenciado" (DE I, 72, p. 875) por elas em favor das "ciências nobres", a arqueologia, além de suspender essa hierarquia, desvia-se de toda tentativa de 
compreender o pensamento clássico pela generalização de um ideal mecanicista ou de matematização da natureza. Desvio que, num primeiro momento, passará justamente por uma demonstração de que a concepção clássica da mathesis não a confunde com esse ideal, na medida em que, segundo Foucault:

a aparição da mathesis como ciência geral da ordem não tivera somente um papel fundador nas disciplinas matemáticas, mas [também][...] tinha sido correlativa da formação de domínios diversos e puramente empíricos como a gramática geral, a história natural e a análise das riquezas; estes não foram construídos segundo um 'modelo' que lhes teria prescrito a matematização ou a mecanização da natureza. (MC, p. 256)

Numa outra passagem, vemos que Foucault, sem se referir a algum autor ou a obras específicas, faz um balanço das caracterizações comuns pelas quais as histórias das ciências e das ideias procuraram traçar o perfil geral do pensamento clássico. Assim, para demarcar a posição da arqueologia nesse debate, ele levanta a necessidade de "distinguir três coisas" (MC, p. 70):

Houve, por um lado, o mecanicismo que por um período, em suma, bastante breve (quase apenas a segunda metade do século XVII) propôs um modelo teórico para certos domínios do saber como a medicina ou a fisiologia. Houve, também, um esforço, bastante diverso em suas formas, de matematização do empírico; constante e contínuo para a astronomia e uma parte da física, ele foi esporádico nos outros domínios - às vezes realmente tentado (como em Condorcert), às vezes proposto como ideal universal e horizonte da pesquisa (como em Condillac e Destutt), às vezes também recusado em sua possibilidade mesma (em Buffon, por exemplo). Mas nem esse esforço nem as tentativas do mecanicismo devem ser confundidos com a relação que todo o saber clássico, em sua forma mais geral, mantém com a mathesis, entendida como ciência universal da medida e da ordem. Sob as palavras vazias, obscuramente mágicas, de 'influência cartesiana' ou de 'modelo newtoniano', os historiadores das ideias têm o hábito de misturar essas três coisas, e de definir o racionalismo clássico pela tentação de tornar a natureza mecânica e calculável. Os outros - os semi-hábeis - esforçam-se por descobrir sob esse racionalismo o jogo de 'forças contrárias': aquelas de uma natureza e de uma vida que não se deixam reduzir nem à álgebra nem à física do movimento e que mantêm assim, no fundo do classicismo, a reserva do não-racionalizável. Essas duas formas de análise são, uma e outra, igualmente insuficientes. (MC, pp. 70-71, grifos meus)

Ao dizer que é preciso fazer a distinção entre o modelo teórico proposto pelo mecanicismo para algumas disciplinas, os diversos esforços de matematização da natureza e a relação de todo saber à mathesis, Foucault não pretende negar que os dois primeiros tenham existido nem tampouco julgar sobre o sucesso ou fracasso dessas experiências. Trata-se, antes, de mostrar que estas foram variações na superfície do saber clássico que, por si mesmas, não esgotam o que foi essa relação "fundamental [à mathesis] [...] que até o fim do século XVIII permanece constante e inalterada" (MC, p. $71)$. 
Esta distinção, portanto, não confronta tais caracterizações gerais a partir do mesmo nível em que elas foram elaboradas por essas outras histórias ${ }^{15}$. Nesse sentido, ela revela uma operação metodológica da análise de Foucault, ou seja, um deslocamento pelo qual ele fixa a sua perspectiva no nível arqueológico do saber. A partir dessa perspectiva arqueológica, a afirmação de que "todo o saber clássico" mantém uma relação com a mathesis pode então ser compreendida como uma primeira transformação que atinge esse nível do saber na primeira metade do século XVII. Ela descreve uma das diferenças fundamentais que Foucault extrai da comparação de conhecimentos que foram efetivamente produzidos na idade clássica com outros produzidos na Renascença - "no fim do século XVI, no início ainda do século XVII" (MC, p. 32). Assim, são essas transformações que, instaurando uma descontinuidade entre dois campos epistemológicos, valem como - dentre as diversas denominações que Foucault atribui para o que se encontra nesse nível arqueológico - "regra", ou "lei", ou "condição de possibilidade", ou "condição de existência" da positividade desses mesmos conhecimentos - e não daqueles que poderiam ter sido produzidos ${ }^{16}$.

\footnotetext{
${ }^{15}$ Foucault define em poucas palavras este nível (ou níveis) da seguinte maneira: "Eu não operei no nível que, habitualmente, é aquele do historiador das ciências - eu deveria dizer nos dois níveis que, habitualmente, são os seus. Por um lado, com efeito, a história da ciência retraça o progresso das descobertas, a formulação dos problemas, registra o tumulto das controvérsias; ela analisa também as teorias em sua economia interna; em suma, ela descreve os processos e os produtos da consciência científica. Por outro lado, todavia, ela tenta restituir o que escapou a essa consciência: as influências que lhe marcaram, as filosofias implícitas que a sustentam, as temáticas não formuladas, os obstáculos invisíveis; ela descreve o inconsciente da ciência. Esse inconsciente é sempre o lado [le versant] negativo da ciência - o que resiste a ela, que a faz desviar ou a perturba." - (DE I, 72, p. 877)

${ }^{16}$ Nesse sentido, essas transformações marcam tanto uma descontinuidade entre duas ordens do saber, quanto consistem naquilo a que se pode atribuir o valor de regras das ordens que elas separam, na medida em que uma transformação não é senão a diferença entre características constantes que pertencem aos próprios elementos ordenados. Em suma, a arqueologia procura descrever uma regularidade imanente aos próprios conteúdos do saber de uma época e que, ao mesmo tempo, determina os próprios limites desse saber. Em 1967, numa carta a Michel Amiot, na qual Foucault responde à crítica de que teria estabelecido uma "descontinuidade sem regra" entre a ordem clássica e a ordem moderna do saber (ordens que ele chamará aí de "dois modelos teóricos"), é esclarecedora a explicação resumida das etapas do seu procedimento descritivo e dessa relação entre transformações e regras:

"De Jussieu à Cuvier, de Thiébaut (sic) à Bopp, de Destutt à Ricardo, a leitura mais ingênua percebe uma diferença tão sensível e imediata quanto a que há entre uma paisagem argilosa e uma paisagem calcária. Esta diferença era a coisa que seria preciso analisar (por isso, evitar de [a] reduzir logo de saída).

Eu tentei estabelecer dois modelos teóricos permitindo descrever o estado A e o estado B de uma parte e de outra deste corte.

Estes dois modelos permitem, além disso, definir em que consistem as "transformações" que permitem passar do estado A ao estado B.

Para que estas transformações definissem a passagem, é preciso que elas sejam todas descritíveis, que elas sejam em número limitado, que elas sejam irreversíveis.

Não se pode dizer que eu estabeleci uma descontinuidade sem regra; mas eu procurei definir um conjunto de transformações que servem de regra à uma descontinuidade empírica." - Michel Foucault. "Lettre de Michel Foucault du 8 mars 1967 en réponse à Michel Amiot". In: Les mots et les choses de Michel Foucault - regards critique 1966 - 1968. Caen: Presses universitaires de Caen, 2009, pp. 136, 138.
} 
Em vista disso, no caso da relação de todo saber clássico à mathesis, trata-se de um exemplo claro de uma regra arqueológica: "o que torna possível o conjunto da epistémê clássica é, primeiro, a relação com um conhecimento da ordem" (MC, p. 86). Foucault the atribui esse valor na medida em que ela foi não só uma constante nesse saber, mas que também consistiu numa transformação em relação a uma característica fundamental do saber da Renascença, que, como veremos logo adiante, foi um saber da Semelhança. Assim, é ao nível dessas transformações que o arqueólogo encontra a possibilidade de realizar uma história daquelas disciplinas empíricas que descreva a sua "regularidade" ou "legitimidade" próprias no interior do campo epistemológico clássico:

[no] domínio empírico em que o homem do século XVI via ainda se emaranhar os parentescos, as semelhanças e as afinidades e onde se entrecruzavam sem fim a linguagem e as coisas - todo esse campo imenso vai assumir uma configuração nova [na idade clássica]. Podemos, se quisermos, designá-la pelo nome de 'racionalismo'; podemos, se não tivermos nada na cabeça senão conceitos já feitos, dizer que o século XVII marca a desaparição das velhas crenças supersticiosas ou mágicas e a entrada, enfim, da natureza na ordem científica. Mas, o que é preciso apreender e tentar restituir são as modificações que alteraram o próprio saber, nesse nível arcaico que torna possiveis os conhecimentos e o modo de ser do que se presta ao saber. (MC, p. 68, grifos meus)

Para que possamos então apreender a relação à mathesis como algo que possui o valor de regra arqueológica que se estende ao conjunto do saber clássico e, consequentemente, como aquilo que "acolhe" a gramática geral, a história natural e a análise das riquezas no interior da regularidade do campo epistemológico dessa época,

É interessante também acompanhar a seguinte resposta de Foucault numa entrevista concedida a Raymond Bellour, na qual, apresentando também essa relação entre transformações e regras, ele mostra o deslocamento da análise arqueológica com relação à história das ideias:

"Nisto que se chama de história das ideias descreve-se em geral a mudança dando-se duas facilidades:

1) Utiliza-se conceitos que me parecem um pouco mágicos, como a influência, a crise, a tomada de consciência, o interesse dirigido a um problema, etc. Todos utilitários, eles não me parecem operatórios.

2) Quando se encontra uma dificuldade, passa-se do nível de análise que é aquele dos próprios enunciados para um outro, que lhe é exterior. Assim, diante de uma mudança, uma contradição, uma incoerência, recorre-se a uma explicação pelas condições sociais, pela mentalidade, pela visão de mundo, etc..

Eu quis, por um jogo metódico, tentar me abster [dessas facilidades] e, por consequência, esforcei-me para descrever os próprios enunciados, grupos inteiros de enunciados, fazendo aparecer as relações de implicação, de oposição, de exclusão que podiam ligá-los.

Disseram-me, por exemplo, que eu aceitara ou inventara um corte absoluto entre o fim do século XVIII e o começo do século XIX. De fato, quando se olha os discursos científicos do fim do século XVIII, constata-se uma mudança muito rápida e bastante enigmática para o olhar mais atento. Eu quis descrever precisamente essa mudança, dito de outro modo, estabelecer o conjunto de transformações necessárias e suficientes para passar da forma inicial do discurso científico, aquele do século XVIII, à sua forma final, aquele do século XIX. O conjunto das transformações que eu defini mantém um certo número de elementos teóricos, desloca alguns outros, vê desaparecer antigos e aparecer novos; tudo isso permite definir a regra de passagem nos domínios que eu considerei." - DE I, 48, pp. 616-617, grifos meus. 
façamos um breve excurso pelo saber da Renascença a fim de ver o que se transformou, quando tal relação passou a ser "constante e inalterada" até o fim do século XVIII.

No saber da Renascença, todas as coisas do mundo aparecem e são conhecidas num campo epistemológico uniforme definido pela Semelhança. Esta, por sua vez, é analisada segundo quatro figuras "essenciais" (MC, p. 33), que "prescrevem suas articulações ao saber da semelhança" (MC, p. 33): a conveniência, a simpatia, a emulação e a analogia. Na conferência intitulada "Nietzsche, Freud, Marx", de 1964, Foucault já definia de maneira sintética essas figuras da semelhança sobre as quais ele tratará em As palavras e as coisas:

sabe-se o papel importante que desempenharam na cosmologia, na botânica, na zoologia, na filosofia do século XVI, a semelhança e todas as noções que giram como satélites em torno dela $[\ldots]$ :

- a noção de conveniência, a convenientia, que é ajustamento (por exemplo da alma e do corpo, ou da série animal à série vegetal);

- a noção de sympatheïa, a simpatia, que é a identidade dos acidentes nas substâncias distintas;

- a noção de emulatio, que é o paralelismo bastante curioso dos atributos nas substâncias ou nos seres distintos, de tal modo que os atributos são como reflexos uns dos outros numa substância e na outra. (Assim, Porta explica que o rosto humano é, com suas sete partes que ele distingue, a emulação do céu e seus sete planetas.); [...]

- e depois, certamente, a noção de analogie, que é a identidade das relações entre duas ou várias substâncias distintas. (DE I, 46, p. 594)

Essas quatro figuras da semelhança definem, no saber renascentista, os modos de relações entre as coisas do mundo, elas "nos dizem como o mundo deve se redobrar sobre si mesmo, reduplicar-se, refletir-se ou encadear-se para que as coisas possam se assemelhar. Elas nos dizem os caminhos da similitude e por onde elas passam" (MC, pp. 40-41, grifos meus). Trata-se de um campo epistemológico cuja configuração é circular, pois, para que o conhecimento possa seguir esses "caminhos" das semelhanças, é necessário que elas sejam de algum modo marcadas, que as coisas apresentem em si mesmas, em seus próprios elementos, os signos visíveis que indiquem as semelhanças invisíveis que as ligam umas às outras. Mas, como veremos na próxima seção, a natureza desses signos não será outra coisa senão essas próprias semelhanças, de maneira que, no saber da Renascença, estas são aquilo que permite conhecer ao mesmo tempo em que está aí, ligando as coisas do mundo, como aquilo a ser conhecido.

A descontinuidade entre a ordem renascentista e a ordem clássica se instaura, negativamente, quando a semelhança deixa de ser a "categoria fundamental do saber ao mesmo tempo forma e conteúdo do conhecimento" (MC, p. 68). A crítica da semelhança que o saber clássico realizará, Foucault já a encontra logo nas primeiras 
linhas de Regras para a orientação do espírito de Descartes ${ }^{17}$. Diferentemente da crítica da semelhança elaborada por Bacon em sua teoria dos "ídolos", que ainda é uma "crítica empírica, que não concerne às relações de ordem e de igualdade entre as coisas, mas aos tipos de espírito e às formas de ilusão às quais eles podem estar sujeitos" (MC, p. 65); no texto cartesiano, para Foucault, trata-se do "pensamento clássico excluindo a semelhança como experiência fundamental e forma primeira do saber, denunciando nela um misto confuso que é preciso analisar em termos de identidade e de diferença, de medida e de ordem" (MC, p. 66). No entanto, como Foucault precisará adiante, esta exclusão da semelhança não significa que ela tenha sido suprimida, ou seja, na nova configuração do saber, ela passará a "habitar" as suas margens, como uma “indispensável borda":

quanto a similitude, doravante, ela só tem que cair fora [retomber hors] do domínio do conhecimento. É o empírico sob sua forma mais grosseira; não se pode mais 'olhá-la como fazendo parte da filosofia', a menos que ela seja apagada na sua inexatidão de semelhança e transformada pelo saber numa relação de igualdade e de ordem. E, todavia, para o conhecimento, a similitude é uma indispensável borda. Pois uma igualdade ou uma relação de ordem só pode ser estabelecida entre duas coisas, se sua semelhança foi ao menos a ocasião para as comparar: Hume colocava a relação de identidade entre aquelas, 'filosóficas', que supõem a reflexão; ao passo que a semelhança pertencia para ele às relações naturais, àquelas que compelem nosso espírito segundo uma 'força calma', mas inevitável. [...] $\mathrm{Na}$ orla exterior do saber, a similitude é essa forma dificilmente esboçada, esse rudimento de relação que o conhecimento deve recobrir em toda sua extensão, mas que, indefinidamente, permanece abaixo dele, à maneira de uma necessidade muda e indelével. (MC, p.82, grifo meu)

Assim, a exclusão da semelhança para as margens do saber não leva consigo o ato de comparação; este, ao contrário, passará a ser uma operação central para todo conhecimento. Esta é uma característica do saber clássico que Foucault também já identifica nas Regras: "se Descartes recusa a semelhança, não é excluindo do pensamento racional o ato de comparação, nem procurando limitá-lo, mas, [...] universalizando-o e dando-lhe, desta maneira, a sua forma mais pura” (MC, p. 66). Doravante, como sintetiza Sabot, "o saber clássico repousa sobre um método de comparação que assegura o progresso dos conhecimentos pela análise regrada da

\footnotetext{
${ }^{17}$ Foucault cita essas linhas (cf. MC, p. 65): "Os homens têm por hábito, em todos os casos em que reconhecem alguma semelhança entre duas coisas, julgar as duas a um só tempo, mesmo no ponto em que elas diferem, aplicando-lhes o que reconheceram como verdadeiro de uma delas". René Descartes. Regras para a orientação do espírito (1629). Trad. de Maria Ermantina Galvão. São Paulo: Martins Fontes, 1999, p. 1.
} 
maneira pela qual os elementos comparados podem se referir uns aos outros e, por essa comparação, instruir sobre a sua verdade" ${ }^{18}$.

Mas, a importância das Regras para Foucault não se esgota em sua crítica da semelhança e na importância dada ao ato de comparação. Juntando-se a isso, será, ainda, daí que ele extrairá os outros elementos necessários para a sua demonstração de que a relação do saber clássico à mathesis vale como a regra arqueológica que torna possível, inclusive, a formação de disciplinas empíricas como a gramática geral, a história natural e a análise das riquezas. Embora a comparação se torne uma operação central para o saber clássico em geral (e não só para a filosofia cartesiana), como diz Ternes, as Regras é um “texto estratégico" para Foucault, já que ele "permite-lhe inserir e privilegiar na epistémê dos séculos XVII e XVIII o não-quantitativo"19. Vejamos, então, como. O primeiro desses elementos consiste em notar que, no saber clássico, "existem duas formas de comparação, e existem somente duas: a comparação da medida e aquela da ordem" (MC, p. 67).

Enquanto no saber da Renascença o conhecimento procurava desvelar as semelhanças que, depositadas no mundo, ligavam as coisas umas às outras, uma vez que, "no século XVI, admitia-se primeiro o sistema global das correspondências (a terra e o céu, os planetas e o rosto, o microcosmo e o macrocosmo), e cada similitude singular vinha se alojar no interior dessa relação de conjunto" (MC, p. 69); no saber clássico, a medida e a ordem são formas de comparação que permitem analisar, "nas coisas representadas, o murmúrio insistente da semelhança” (MC, p. 83, grifo meu). A preponderância dessas formas de comparação no saber clássico denuncia, de um ponto de vista arqueológico,

[a] substituição da análise à hierarquia analógica [...]; doravante, toda semelhança será submetida à prova da comparação, quer dizer que ela só será admitida uma vez encontrada, pela medida, a unidade comum, ou, mais radicalmente pela ordem, a identidade e a série das diferenças. (MC, p. 69, grifos meus)

Esta passagem já aponta para o outro elemento que Foucault "pinça" no texto de Descartes, mas, sempre, para mostrar que ele possui uma amplitude "mais geral que a fortuna singular do cartesianismo" (MC, p, 70). A comparação pela medida analisa o semelhante segundo uma "forma calculável" (MC, p. 67). Ela requer, primeiramente, a

\footnotetext{
${ }^{18}$ Philippe Sabot. Le Même et l'Ordre - Michel Foucault et le savoir à l'âge classique. Lyon: ENS Éditions, 2015, p. 58

${ }^{19}$ José Ternes. Michel Foucault e a idade do homem. Goiânia: Editora da UFG, Editora da UCG, $2^{\text {a }}$ edição, 2009, p. 22.
} 
análise das "grandezas contínuas ou descontínuas", cuja semelhança dá ensejo à comparação, ou seja, requer que partamos da consideração do "todo e que o dividamos em partes" (MC, p. 67), a fim de aplicar a cada uma das grandezas uma unidade de medida comum, que permitirá compará-las. Estas unidades "são de convenção ou 'de empréstimo' (para as grandezas contínuas) e as outras (para as multiplicidades ou grandezas descontínuas) são as unidades da aritmética” (MC, p. 67). Assim, uma vez aplicada uma destas unidades ao que foi analisado, "a comparação efetuada pela medida se reduz, em todos os casos, às relações aritméticas da igualdade e da desigualdade" (MC, p. 67, grifos meus). A comparação pela ordem, por sua vez, "é um ato simples" (MC, p. 67): “enquanto a comparação pela medida exigia primeiro uma divisão, depois a aplicação de uma unidade comum, aqui comparar e ordenar são uma única e mesma coisa" (MC, p. 67). Pelo ordenamento, considera-se, inicialmente, as coisas mais simples e se passa gradualmente às mais complexas e, assim, "estabelecem-se séries em que o termo primeiro é uma natureza da qual se pode ter a intuição independentemente de todas as outras; e em que os outros termos são estabelecidos segundo diferenças crescentes" (MC, p. 67).

Mas, se a princípio essas duas formas de comparação se diferenciam, elas não se excluirão. Este é o detalhe crucial que Foucault destaca nas Regras e que o leva a definir a relação à mathesis como uma regra arqueológica que se estende ao conjunto do saber clássico. Quer dizer, trata-se de apontar que, entre essas formas de comparação, há um "desequilíbrio fundamental" (MC, p. 71), que permite "conduzir a medida das grandezas e das multiplicidades ao estabelecimento de uma ordem" (MC, p. 68):

\begin{abstract}
os valores da aritmética são sempre ordenáveis segundo uma série: a multiplicidade das unidades pode então 'se dispor segundo uma ordem tal que a dificuldade, que pertencia ao conhecimento da medida, acabe por depender apenas da consideração da ordem'. E é justamente nisso que consistem o método e seu 'progresso': conduzir toda medida (toda determinação pela igualdade e a igualdade) à uma colocação em série que, partindo do simples, faz aparecer as diferenças como graus de complexidade. O semelhante, depois de ser analisado segundo a unidade e as relações de igualdade ou de desigualdade, analisa-se segundo a identidade evidente e as diferenças: diferenças que podem ser pensadas na ordem das inferências. (MC, p. 68)
\end{abstract}

O propósito de chamar a atenção para este detalhe nas Regras, ou seja, que "sempre se pode conduzir os problemas da medida àqueles da ordem” (MC, p. 71), consiste em mostrar que, no saber clássico, a mathesis é uma ciência prioritariamente da ordem. E, para Foucault, isto é o que determina um dos "caracteres essenciais" (MC, p. 71) da relação dos conhecimentos a ela, pois a prevalência da ordem sobre a medida 
define esta relação "como a possibilidade de estabelecer entre as coisas, mesmo não mensuráveis, uma sucessão ordenada.” (MC, p. 71, grifos meus).

É precisamente essa prevalência que o levava a afirmar, como vimos acima, que a relação do saber à mathesis não deve ser confundida com o modelo mecanicista e nem com os esforços de matematização da natureza. Daí, também, determina-se o seu segundo "caráter essencial". Tomada nessa acepção de uma ciência geral da ordem, a mathesis foi o solo no qual se formaram mesmo as disciplinas que não se servem do cálculo (da álgebra); disciplinas cujo corpus de conhecimentos se constituiu prescindindo da medida, já que nelas, "diretamente e como que sem dificuldade [de plain-piede], a comparação é referida à ordem" (MC, p. 68).

Assim, esse "desequilíbrio" entre a ordem e a medida implicado nessa concepção da mathesis é o dado fundamental a partir do qual Foucault estabelece que a relação dos conhecimentos a ela é uma regra arqueológica que se estende ao conjunto do saber clássico. Noutras palavras, essa relação é um traço constitutivo desse saber, descrevendo, ao nível arqueológico, uma primeira linha de regularidade que ultrapassa, mas também atravessa, todo o domínio empírico da gramática geral, da história natural e da análise das riquezas. Essas disciplinas, longe de terem se formado a partir de um propósito de matematização do empírico, diz Foucault, “constituíram-se e dispuseramse sobre o fundo de uma possibilidade geral: aquela que permitia estabelecer entre as representações um quadro ordenado das identidades e das diferenças." (MC, p. 256, grifos meus)

Foucault, no entanto, lembrará que, se no saber da Renascença o conhecimento trilhava "os caminhos da similitude" através dos signos que as indicavam e, assim, procurava "revelar o ordenamento do mundo" (MC, p. 68, grifos meus); no saber clássico, “a comparação [...] se faz segundo a ordem do pensamento[,] [...] indo naturalmente do simples ao complexo" (MC, p. 68, grifos meus), e mesmo "o caráter absoluto que se reconhece ao que é simples não concerne ao ser das coisas, mas, sim, à maneira que elas podem ser conhecidas" (MC, p. 68). Isso, certamente, já deixa entrever que, no saber clássico, o sentido deixará de pertencer ao mundo para alojar-se no espaço da representação. Na próxima seção trataremos do motivo desta deserção, pois, antes, cumpre perguntar: se "essa relação à mathesis como ciência geral da ordem não significa uma absorção do saber nas matemáticas, nem que nelas se fundamente todo conhecimento possível” (MC, p. 71), de qual meio aquelas disciplinas empíricas se valem para conhecer a ordem dos seres dos quais elas se ocupam? 
Como dissemos no início, Foucault pretende descrever a formação particular da gramática geral, da história natural e da análise das riquezas: "ciências da ordem no domínio das palavras, dos seres e das necessidades" (MC, p. 71). Assim, se a relação à mathesis é um traço constitutivo do saber clássico em geral, se através dele a arqueologia mostra o pertencimento dessas disciplinas ao campo epistemológico dessa época, uma primeira característica que mostrará a particularidade da formação do domínio dessas disciplinas no interior desse campo será o meio do qual elas se valeram para conhecer a ordem. Quer dizer, nas palavras de Foucault, "este domínio empírico repousava sobre o projeto de um ordenamento das coisas, e isto não graças às matemáticas, à geometria, mas graças a uma sistemática dos signos, uma espécie de taxinomia geral e sistemática das coisas" (DE I, 34, p. 528, grifos meus).

Em vista disso, Foucault descreve uma disposição geral do saber clássico que se organiza como um sistema. Neste encontram-se as ciências que se valem do cálculo algébrico para conhecer os seus objetos, isto é, que a partir da "forma calculável" da comparação pela medida buscam conhecer as "naturezas simples" segundo as relações aritméticas de igualdade ou de desigualdade. Mas, convivendo com essas ciências no mesmo campo epistemológico, também se encontram as disciplinas empíricas privilegiadas pela análise do saber clássico. Se aquelas tratam matematicamente os seus objetos, estas, por sua vez, valem-se de um sistema de signos para conhecer os seus, isto é, de signos que as permitem proceder diretamente (sem passar pela medida) ao estabelecimento de "ordens não quantitativas" (MC, p. 90) das "naturezas complexas". Para essas disciplinas, os signos, como diz Foucault, são "chaves para uma taxinomia" (MC, p. 72), de modo que, nelas, o ordenamento se faz por uma classificação que estabelece as representações dos seres empíricos num quadro, segundo as suas identidades e diferenças:

quando se trata de ordenar as naturezas simples, recorre-se a uma mathesis, cujo método universal é a Álgebra. Quando se trata de colocar em ordem naturezas complexas (as representações em geral, tal como elas são dadas na experiência), é preciso constituir uma taxinomia e, para fazer isso, instaurar um sistema de signos" (MC, p. 86)

Ora, ao contrapor desta maneira mathesis e taxinomia, Foucault não estaria então excluindo as disciplinas empíricas do campo epistemológico clássico? E ele não estaria assim se contradizendo, indo de encontro a todo seu esforço de mostrar que essas disciplinas pertencem a esse campo? De fato, Foucault faz uma diferenciação entre mathesis e taxinomia: "entendida em sentido estrito, a mathesis é ciência das 
igualdades, logo das atribuições e dos julgamentos; é a ciência da verdade; já a taxinomia trata das identidades e das diferenças; é a ciência das articulações e das classes; ela é o saber dos seres." (MC, p. 88, grifo "sentido estrito"). Mas, aqui, mais uma vez nos deparamos com a importância que ele atribui àquele "desequilíbrio fundamental" através do qual ele mostra que, num sentido lato, a mathesis é uma ciência prioritariamente da ordem, já que, em última análise, a medida e o estabelecimento das relações de igualdade ou desigualdade podem ser conduzidos a um ordenamento segundo identidades e diferenças. Assim, uma vez que "o ordenamento por meio dos signos constitui todos os saberes empíricos como saberes da identidade e da diferença” (Mc, p. 71), esses saberes que não passam por uma comparação pela medida não escapam a essa primeira regra arqueológica geral, isto é, eles se formaram em relação à mathesis. Nesse sentido, Foucault pode afirmar que a "taxinomia não se opõe à mathesis: aloja-se nela e dela se distingue; pois ela também é uma ciência da ordem - uma mathesis qualitativa." (MC, p. 88). Ou seja, para Foucault, ao nível arqueológico, o saber clássico possui uma disposição sistemática em que mathesis e taxinomia não se excluem:

\begin{abstract}
os signos são para a ordem das naturezas compostas o que é a álgebra para a ordem das naturezas simples. Mas, na medida em que as representações empíricas devem poder se analisar em naturezas simples, vê-se que a taxinomia se refere inteiramente à mathesis; em contrapartida, uma vez que a percepção das evidências não é senão um caso particular da representação em geral, pode-se dizer também que a mathesis não é senão um caso particular da taxinomia. Do mesmo modo, os signos que o próprio pensamento estabelece constituem como uma álgebra das representações complexas; e a álgebra, inversamente, é um método para dar signos às naturezas simples e para operar sobre esses signos. Tem-se então a disposição seguinte:
\end{abstract}

Ciência geral da ordem

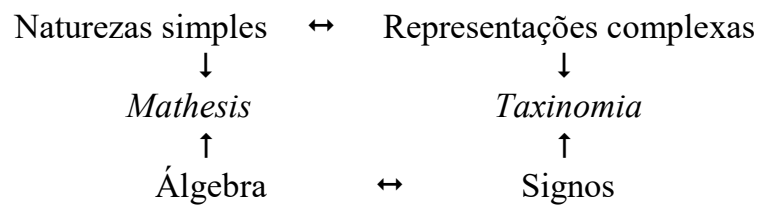

(MC, p. 87)

Neste ponto, o leitor poderia se perguntar por que trazemos à baila essa sistematização complexa do saber clássico. Com ela, podemos apontar, na disposição geral do saber clássico, "onde" se encontra o domínio em que interessa a Foucault tratar da ligação da linguagem com a representação e com os conhecimentos. Trata-se do domínio em que os conhecimentos procedem ao ordenamento das representações complexas prescindindo do cálculo e servindo-se de um sistema dos signos; domínio em 
que a ordem das representações se estabelece através de uma classificação dos seres num quadro, segundo as suas identidades e diferenças; e que, nesse sentido, Foucault considera como o domínio de uma "mathesis qualitativa" - lado direito do esquema acima. Será para este domínio que estará voltada a nossa atenção nas duas próximas seções.

\section{Representação e Discurso: a relação da linguagem com o conhecimento das ordens empíricas}

O seguinte trecho de As palavras e as coisas sintetiza tudo o que nos importa neste momento para nos aproximarmos da relação da linguagem com o conhecimento no saber clássico:

\footnotetext{
a linguagem era um conhecimento e o conhecimento era de pleno direito um discurso. Em relação a todo conhecimento, ela se encontrava numa situação fundamental: não se podia conhecer as coisas do mundo senão passando por ela. (MC, p. 309, grifos meus)
}

No que diz respeito a essa passagem, a primeira coisa que devemos sublinhar é que Foucault delimita bem o campo no qual lhe interessa descrever como a linguagem aparece numa "situação fundamental" em relação ao conhecimento, ou seja, o campo em que se trata de conhecer "as coisas do mundo", o campo dos conhecimentos empíricos. Em segundo lugar, é preciso destacar que, em relação às "coisas do mundo", a linguagem se apresenta como o meio através do qual elas vêm a ser conhecidas: o modo próprio de conhecer as empiricidades na idade clássica implica necessariamente que se "passe" pela linguagem. Ora, por que tudo isso poderia consistir numa particularidade do saber clássico e, especificamente, do saber clássico das empiricidades? Em qualquer época, os conhecimentos científicos não devem ser mediados pela linguagem para que se expressem como tais?

Por mais que essa ideia possa parecer trivial, ela aponta diretamente para aquilo que, como vimos na seção anterior, distingue, no saber clássico, a formação da gramática geral, da história natural e da análise das riquezas:

em correlação com a busca de uma mathesis, vê-se aparecer um certo número de domínios empíricos. Em nenhum desses domínios, ou quase, é possível encontrar vestígio de um mecanicismo ou de uma matematização; e todavia, todos eles se constituíram sobre o fundo de uma ciência possível da ordem. Se eles se erguem a partir da Análise em geral, seu instrumento particular não 
era o método algébrico, mas o sistema dos signos. (MC, p. 71, grifo "instrumento")

Se a relação a uma "ciência universal da ordem" (MC, p. 71) é, antes de tudo (cf. MC, p. 86), um dos traços constitutivos do conjunto do saber clássico, esses domínios empíricos se particularizam na medida em que o meio pelo qual eles necessariamente passam para conhecer a ordem, em seus respectivos campos de objetos (as palavras, os seres vivos e as relações econômicas), é um "sistema de signos" e, especialmente, a linguagem enquanto um sistema de signos verbais. Isto significa que a linguagem não era simplesmente uma maneira de exprimir os conhecimentos, pois, antes, ligada ao próprio ato de conhecimento, "ela era o primeiro esboço de uma ordem nas representações do mundo; porque ela era a maneira inicial, inevitável, de representar as representações." (MC, p. 309, grifos meus). Em vista disso, podemos perguntar: como a linguagem se liga ao conhecimento, encontrando-se em relação a ele numa "situação fundamental"? Além disso, qual seria a sua peculiaridade para que ela desempenhe esse papel "inevitável” no conhecimento das ordens empíricas? São com essas questões que gostaríamos de lidar ao longo desta segunda seção, o que requer que acompanhemos essa espécie de ontologia da linguagem clássica que Foucault realiza em As palavras e as coisas.

A primeira característica do modo de ser da linguagem clássica que Foucault descreve é a de que a sua relação com o pensamento, mais do que por uma mera proximidade, pode ser definida por uma identidade. As palavras não são encarregadas de traduzir o pensamento, como uma série independente que acompanharia a série das representações; tampouco, encarregam-se de ser a sua reprodução material (escrita ou falada), como se fossem o próprio pensamento depositado no mundo (cf. MC, p. 92):

\footnotetext{
as palavras não formam então a fina película que duplica o pensamento do lado da sua fachada; elas o evocam, elas o indicam, mas, antes, do interior, em meio a todas estas representações que representam outras. A linguagem clássica, muito mais do que se crê, está próxima do pensamento que ela é encarregada de manifestar; mas ela não lhe é paralela; ela está presa na sua rede e tecida na própria trama que ele desenrola. Não é efeito exterior do pensamento, mas o próprio pensamento. (MC, pp. 92-93)
}

Pode-se dizer então que a presença da linguagem no saber clássico é "soberana", pois ela "representa o pensamento, como o pensamento se representa a si mesmo" (MC, p. 92). E Foucault designa claramente o espaço onde linguagem e pensamento se identificam: "a linguagem está aí, nesta distância [écart] que a representação estabelece 
a si mesma" (MC, p. 92), ela "se desdobra no interior da representação e nesta duplicação de si mesma que a escava" (MC, p. 93). Como entender essas afirmações?

\subsection{A teoria clássica dos signos e o "primado da representação"}

O que podemos perceber de saída é que essa identidade entre os signos verbais e o pensamento aponta para o fato de que, no saber clássico, "a análise da representação e a teoria dos signos se penetram absolutamente uma na outra" (MC, p. 79), de tal maneira que, ao se tratar dos signos, é o próprio modo de ser da representação que é visado: a representação e o signo são "perfeitamente transparentes um ao outro" (MC, p. 79). Para um saber em que, segundo Foucault, há um "primado da representação" (MC, p. 348), este é um dado fundamental. Mas, por isso mesmo, não podemos simplesmente nos contentar em tomá-lo como um “dado". É imprescindível, portanto, que, antes de tratar diretamente da linguagem, procuremos saber por que entre os signos em geral e a representação há essa "transparência" e qual é a importância disso para a arqueologia do saber clássico.

Esta transparência não é senão uma consequência (cf. MC, p. 79) que a arqueologia extrai da descrição do que, a partir da metade do século XVII, passou a ser a "propriedade mais fundamental dos signos" (MC, p. 77). Aí se instaura uma "organização estritamente binária" (MC, p. 78) do signo, em que a relação entre um elemento significante e o elemento significado se dá sem qualquer intermediação de um terceiro. Na perspectiva de uma história dos signos ${ }^{20}$, trata-se de um acontecimento da maior importância, já que, segundo Foucault, "a disposição binária do signo, tal como ela aparece no século XVII, substitui-se a uma organização que, de modos diferentes, fora sempre ternária, desde os estoicos e mesmo desde os primeiros gramáticos

\footnotetext{
${ }^{20}$ Na discussão que se segue à conferência pronunciada no Colóquio de Royaumont, em julho de 1964, intitulada "Nietzsche, Freud, Marx" - na qual os trabalhos desses autores são apresentados como fundadores da hermenêutica moderna (ideia que é retomada em As palavras e as coisas (cf. MC, pp. 310311)) -, a advertência que Foucault faz, ao final da sua resposta a um interlocutor que dizia que a hermenêutica moderna começaria, na verdade, com Hegel, também é válida para a compreensão da sua análise do saber clássico, em particular, e mesmo do conjunto de As palavras e as coisas: "na história dos signos, tomada na sua maior extensão, a descoberta das línguas indo-europeias, a desaparição da gramática geral, a substituição do conceito de organismo por aquele de caráter, não são menos 'importantes' que a filosofia hegeliana. Não se deve confundir história da filosofia e arqueologia do pensamento" (DE I, 46, p. 603, grifos meus).
} 
gregos"21 (MC, p. 79). Assim, será por comparação $o^{22}$ com a natureza ternária do signo que Foucault lança luz sobre a sua nova disposição no saber clássico, comparação que permite descrever uma série de diferenças entre ambas e que dão o contorno desse acontecimento, isto é, diferenças que mostram o que o signo deixou de ser quando a sua binariedade aparece positivamente. Entretanto, dentre os diversos modos que a natureza ternária do signo assumiu desde a Antiguidade ${ }^{23}$, Foucault se limita a descrever aquele que vigorou no saber renascentista. É para ele, então, que devemos nos voltar por um instante, para que, em seguida, possamos tratar da natureza binária do signo no saber clássico - contraponto cuja importância para as questões que levantamos nesta seção, mas também para o próprio diagnóstico do presente de As palavras e as coisas, irá se tornar patente.

No saber renascentista, a "proliferação maravilhosa das semelhanças" foi "preparada, desde muito tempo, pela ordem do mundo e para o nosso maior benefício" (MC, p. 41). Por isso, não há uma única semelhança que não tenha sido marcada e, como diz Paracelso numa passagem citada por Foucault, mesmo que estas marcas não sejam imediatamente manifestas, Deus, com o propósito de que os homens pudessem reconhecê-las, depositou-as no mundo deixando-as visíveis de alguma maneira (cf. MC, p. 41). O conhecimento das semelhanças, portanto, deve passar necessariamente pelo reconhecimento dos signos que as indicam, quer dizer, dessas marcas sem as quais elas jamais poderiam ser descobertas. Mas como um signo pode ser reconhecido como tal?

"Para nossos olhos de pessoas do século XX", diz Foucault, "toda esta rede de similitudes é bastante confusa e desordenada. Na verdade, este corpus da semelhança no século XVI era perfeitamente organizado" (DE I, 46, p. 593). Esta organização é o que a arqueologia do saber renascentista traz à tona; ela nos mostra que aquelas quatro figuras essenciais da similitude, sobre as quais tratamos na seção anterior (a conveniência, a

\footnotetext{
${ }^{21}$ Isto é o que também nos diz Edmod Ortigues em $O$ discurso e o símbolo (1962): "A distinção do signans e do signatum é antiga. [...] Na história dessa distinção convirá destacar duas coisas: a fórmula, que era primeiramente tripartite, tornou-se em seguida [no século XVII, com a Lógica de Port-Royal] bipartite; e esta ligeira variação provém, sem dúvida, de que a fórmula não preencheu sempre a mesma função, não serviu sempre para resolver o mesmo gênero de problemas." - Edmond Ortigues, Le discours et le symbole. Paris: Beauchesne, 2007, p. 81.

${ }^{22}$ No "Prefácio à edição inglesa" (1970) de As palavras e as coisas, Foucault afirma: "Este livro deve ser lido como um estudo comparado, e não como um estudo sintomatológico. Minha intenção não foi, a partir de um tipo particular de saber ou de um corpus de ideias, pintar o retrato de um período ou reconstituir o espírito de um século. Procurei apresentar, uns ao lado dos outros, um número bem preciso de elementos - o conhecimento dos seres vivos, o conhecimento das leis da linguagem e o conhecimento dos fatos econômicos - e ligá-los ao discurso filosófico de seu tempo, durante um período que se estende do século XVII ao século XIX.” (DE I, 72, p. 876)

${ }^{23}$ Para uma breve explicação sobre a natureza ternária do signo nos estoicos e na Idade Média, cf. Edmond Ortigues, Le discours et le symbole. Paris: Beauchesne, 2007, pp. 81-82.
} 
simpatia a emulação e a analogia), formam um "sistema" 24 (MC, p. 40). Esse sistema, no entanto, não estaria completo se àquelas figuras não se acrescentasse uma quinta similitude dotada de um caráter particular. Trata-se das assinaturas [signatures]: estas são, "dentre as propriedades visíveis de um indivíduo, a imagem de uma propriedade invisível e oculta" (DE I, 46, p. 594). Ou seja, as assinaturas são os signos visíveis depositados por Deus nas próprias coisas e, na medida em que as "propriedades" invisíveis destas últimas são alguma daquelas outras quatro formas da similitude, as

\footnotetext{
${ }^{24}$ Vê-se já por aqui a vocação estruturalista de Foucault. Mas isto se entendermos tal vocação como algo próximo daquela que possui um suposto estudante, descrito por Barthes, que pretendia realizar uma análise estrutural de uma obra literária. "Este herói - ou este sábio", entre tantas qualidades que Barthes lhe atribui como pré-requisitos para começar a sua análise, seria "bastante dialético, enfim, para bem se persuadir de que não se trata de obter uma 'explicação' do texto, um 'resultado positivo' (um significado último que seria a verdade da obra ou sua determinação), mas, ao inverso, que se trata de entrar, pela análise (ou o que se assemelha à uma análise) no jogo do significante, na escritura: numa palavra, de realizar, pelo seu trabalho, o plural do texto" - Roland Barthes. Le degré zéro de l'écriture - suivi de nouveaux essais critiques. Paris: Éditions du Seuil, 1952 et 1972, p. 140. Mas também poderíamos pensar nesta vocação estruturalista de Foucault como a partilha com Barthes de um certo "prazer do Sistema", tal como este último diz ter experimentado durante um período da sua experiência intelectual: "para mim, o que domina este período do meu trabalho [de 1957 a 1963], eu creio, é menos o projeto de fundar semiologia como ciência, que o prazer de exercer uma Sistemática: há, na atividade de classificação [classement] um tipo de embriaguez criativa que foi aquela dos grandes classificadores, como Sade e Fouret; na sua fase científica, a semiologia foi para mim essa embriaguez; eu reconstituía, eu bricolava (dando um sentido elevado a esta expressão) sistemas, jogos; eu jamais escrevi livros senão pelo prazer: o prazer do Sistema substituía em mim o super-eu da Ciência" - Roland Barthes. L'aventure sémiologique. Paris: Éditions du Seuil, 1985, p. 12. No caso de Foucault, todavia, é conhecida a ambiguidade desta sua vocação e, com efeito, não nos parece que ganhamos muita coisa procurando saber se ele foi ou não um estruturalista strictu-senso. Até porque Foucault mesmo nos adverte que a questão de saber se um autor é ou não estruturalista é uma falsa questão. Como ele afirma: "o estruturalismo é uma categoria que existe para os outros [...]. É do exterior que se pode dizer: este, aquele e aquele outro são estruturalistas" (DE I, 55 , p. 693). Isto é, era claro para ele que "não pode haver uma teoria geral do estruturalismo" (DE I, 47, p. 612). O que não descarta a possibilidade de que uma comparação do seu trabalho com aqueles dos ditos estruturalista possa suscitar questões interessantes. Poderíamos nos perguntar, por exemplo, se o "discurso", tal como ele procurou defini-lo como material da descrição/análise arqueológica, seria esgotado no "jogo significante" da "língua", tal como ela foi definida, primeiramente, no fim do século XIX, pela linguística de Saussure e que serviu de "modelo formal" (MC, p. 392) para a crítica literária, para a psicanálise e para a etnologia, ao que parece, principalmente, a partir dos trabalhos de Jakobson. Aliás - para voltarmos ao nosso comentário do saber renascentista -, ao realizar uma descrição da transformação da natureza do signo no século XVII, Foucault não estaria nos contando justamente a história desse jogo? Se este for o caso, poderíamos bem pensar que a sua "arqueologia das ciências humanas" é um trabalho histórico que, em alguma medida, responderia à indicação feita por Barthes na "Introdução" de Elementos de semiologia, em 1964: "a classificação binária dos conceitos parece frequente no pensamento estrutural, como se a metalinguagem do linguista reproduzisse 'de cima a baixo' ['en abyme'] a estrutura binária do sistema que ele descreve; e, indicaremos de passagem que seria, sem dúvida, muito instrutivo estudar a preeminência da classificação binária no discurso das ciências humanas contemporâneas: a taxinomia dessas ciências; se ela fosse bem conhecida, certamente informaria sobre o que se poderia chamar de imaginário intelectual da nossa época" - Roland Barthes. L'aventure sémiologique. Paris: Éditions du Seuil, 1985, p. 20. Um dado biográfico que aparece na "Cronologia", estabelecida por Daniel Defert para Ditos e escritos, vem reforçar esta suspeita: "Outubro [de 1963]: [...] Abandonando a sequência prevista para a História da loucura, que devia tratar da história da psiquiatria penal, ele [Foucault] começa 'um livro sobre os signos' [As palavras e as coisas]. Um trabalho intenso interrompe o ritmo dos jantares com Roland Barthes em Saint-Germain-des-Prés; suas relações se distendem" - DE I, “Cronologia”, p. 32.
} 
assinaturas são o que permite conhecê-las, fazendo-as passar à visibilidade. Nas palavras de Foucault:

o sistema das assinaturas inverte a relação do visível ao invisível. A semelhança era a forma invisível do que, do fundo do mundo, tornava as coisas visíveis; mas, para que essa forma, por sua vez, venha à luz, é preciso uma figura visível que a tire da sua profunda invisibilidade. (MC, pp. 41-42)

Neste sentido, pode-se dizer que, na Renascença, o mundo fala, que as assinaturas visíveis na sua superfície são as "palavras" que compõem a sua linguagem e fazem dele como que um "grande livro aberto" (MC, p. 42) para ser decifrado:

O grande espelho calmo no fundo do qual as coisas se miravam e se reenviavam, uma à outra, suas imagens, é, na realidade, todo murmurante de palavras. Os reflexos mudos são duplicados pelas palavras que os indicam. E graças a uma última forma de semelhança que envolve todas as outras e as fecha num círculo único, o mundo pode se comparar a um homem que fala (MC, p. 42, grifos meus).

Entretanto, se a assinatura, enquanto "uma última forma de semelhança", fecha o sistema das similitudes, ela o faz se elevando em relação ao plano de todas as outras, justamente na medida em que ela "envolve todas as outras" quatro. Ou seja, a razão deste deslocamento é que a assinatura, como uma figura "curinga", só é visível sob a forma de alguma das outras quatro figuras da similitude. Esta é a sua peculiaridade, é ela que define a assinatura como uma figura da similitude distinta das outras e, portanto, ela é o que lhe dá a possibilidade de ser reconhecida como tal. A assinatura, diz Foucault,

\footnotetext{
é uma outra semelhança, uma similitude vizinha e de um outro tipo que serve para reconhecer a primeira [invisível], mas que é detectada por sua vez por uma terceira [visível]. Toda semelhança recebe uma assinatura; mas essa assinatura não é senão uma forma intermediária da mesma semelhança. (MC, p. 44 , grifos meus)
}

Para que isso fique mais claro, vejamos um dos exemplos que Foucault apresenta. O que permite reconhecer o signo da simpatia entre duas coisas?

Há simpatia entre o acônito e os olhos. Esta afinidade imprevista permaneceria na sombra se não houvesse sobre a planta uma assinatura, uma marca e como que uma palavra dizendo que ela é boa para as doenças do olho. Este signo é perfeitamente legível nas suas sementes: estas são pequenos globos cinzentos engastados em películas brancas, que figuram aproximadamente o que as pálpebras são para os olhos. [...] $\mathrm{O}$ signo da afinidade, e o que a torna visível, é simplesmente a analogia; a cifra da simpatia reside na proporção. (MC, p. 42)

A assinatura, enquanto uma figura distinta da similitude, pode ser reconhecida e revelar a simpatia oculta entre o acônito e os olhos somente porque ela aparece na forma 
de uma analogia visível que a semente do primeiro apresenta com os segundos: é sob a forma desta analogia que a assinatura possui a possibilidade de trazer à luz a simpatia. Apresentando assim a assinatura como a figura que vem completar o "sistema" das figuras da similitude, Foucault afirma que isto só é possível por se tratar de um "sistema de reduplicações" (MC, p. 43):

\begin{abstract}
o conjunto das marcas faz deslizar, sobre o círculo das similitudes, um segundo círculo que reduplicaria exatamente e ponto por ponto o primeiro, não fosse este pequeno deslocamento que faz com que o signo da simpatia resida na analogia, aquele da analogia na emulação, aquele da emulação na conveniência, que requer por sua vez para ser reconhecida a marca da simpatia... A assinatura e o que ela designa são exatamente da mesma natureza; eles apenas obedecem uma lei de distribuição diferente; o recorte é o mesmo. (MC, p. 44, grifos meus)
\end{abstract}

Desta maneira se configura a natureza do signo na Renascença, envolvendo três figuras da semelhança. No saber desta época, sendo marcada por um signo, a relação entre duas coisas nunca é simples, pois ela se reparte em duas relações de ordens distintas, isto é, numa relação visível e numa relação invisível. Assim, o signo, isto é, a assinatura (1), enquanto uma forma distinta da semelhança que opera a passagem do invisível para o visível, encerra aquelas duas relações: conforme o exemplo, uma analogia visível (2) da semente do acônito com os olhos, que a eleva à condição de significante; e uma simpatia invisível (3) que é o seu significado.

Embora haja a necessidade de que as assinaturas sejam oblíquas em relação às similitudes que elas indicam (já que se o círculo das assinaturas fosse homólogo ao círculo das similitudes aquelas não poderiam ser reconhecidas como tais), este "pequeno deslocamento" não consiste numa deserção dos signos, não os retira do mundo onde se encontram as coisas que se ligam pelas semelhanças que eles significam e, tampouco, instaura uma relação arbitrária entre os seus termos (significante $e$ significado). O signo está imbricado, como um elemento delas, nas próprias coisas que ele reúne (a semente do acônito) e cujas relações invisíveis de umas com as outras ele é encarregado de manifestar. Além disso, a relação dos seus termos, que são "exatamente da mesma natureza”, é tão estreita, que a assinatura significa na medida em que é "quase a mesma coisa" 25 que o significado (a simpatia entre o acônito e os olhos); quer dizer, na medida em que o que o eleva como um significante é uma semelhança, mas

\footnotetext{
${ }^{25} \mathrm{Na}$ Renascença, "a teoria do signo implicava três elementos perfeitamente distintos: o que era marcado, o que era marcante e o que permitia ver neste a marca daquele; ora, este último elemento era a semelhança: o signo marcava na medida em que era 'quase a mesma coisa' que ele designava" (MC, p. 78)
} 
não a mesma que ele significa (é a analogia com os olhos que faz da semente um significante e não a simpatia). A semelhança, portanto, constitui toda a natureza do signo no século XVI:

As semelhanças exigem uma assinatura, pois nenhuma dentre elas poderia ser notada se ela não fosse legivelmente marcada. Mas quais são estes signos? $\mathrm{O}$ que nos leva a reconhecer, dentre todos os aspectos do mundo e tantas figuras que se entrecruzam, que há aqui um caractere no qual convém se deter, pois ele indica uma secreta e essencial semelhança? Qual forma constitui o signo em seu singular valor de signo? - É a semelhança. (MC, pp. 43-44)

Os signos, portanto, são coisas entre as coisas. E o reenvio ilimitado de umas às outras, conduzido pela "infinita riqueza de uma semelhança introduzida como terceiro entre os signos e seus sentidos" (MC, p. 47), articulava, no século XVI, a "prosa do mundo". Em vista disso, podemos retornar à análise da natureza binária do signo com os elementos necessários para compreender a transformação que se passou na metade do século XVII. Foucault resume da seguinte maneira esta transformação:

Desde o estoicismo, o sistema dos signos no mundo ocidental tinha sido ternário, já que se reconhecia aí o significante, o significado e a 'conjuntura'

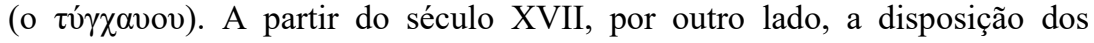
signos se tornará binária, já que ela se definirá, com Port-Royal, pela ligação de um significante e de um significado. Na Renascença, a organização é diferente, e muito mais complexa; ela é ternária, já que ela faz apelo ao domínio formal das marcas, ao conteúdo que se encontra assinalado por elas $\mathrm{e}$ às similitudes que ligam as marcas às coisas designadas; mas como a semelhança é tanto a forma dos signos quanto o seu conteúdo, os três elementos distintos desta distribuição se resolvem numa figura única. (MC, p. 57)

É, pois, na Lógica de Port-Royal que Foucault encontra o maior testemunho desta transformação na história dos signos. Aí, numa "teoria dual do signo" (MC, p. 78), este é a "ligação de um significante e de um significado". Esta nova disposição, segundo Foucault, faz-se acompanhar de um problema que até então não podia ser colocado em relação ao signo, ou melhor, é ela que torna possível o aparecimento de uma nova questão. Como diz François Wahl, "o Renascimento nos remete a uma forma de inocência ou de felicidade perdidas do signo, da qual estaríamos hoje na maior das distâncias" ${ }^{26}$. Quer dizer, uma vez que na Renascença não havia arbitrariedade entre o significante e o significado, já que a ligação entre eles era preestabelecida por Deus, sendo dada no mundo sob a forma de uma semelhança intermediária, o que aparecia como um problema era como reconhecer tal ligação. A partir da idade clássica, quando o signo assumirá uma disposição binária, quando ele deixará de dispor de um elemento

\footnotetext{
${ }^{26}$ François Wahl. "Há uma epistemê estruturalista? Ou de uma filosofia aquém do estruturalismo: Michel Foucault”. In: Estruturalismo e filosofia. São Paulo: Editora Cultrix, s.d., p. 21.
} 
intermediário que assegurava de antemão, "na ordem das próprias coisas" (MC, p. 77), a ligação do significante e do significado, aparecerá "um novo problema, até então desconhecido" (MC, p. 58):

com efeito, [no século XVI] perguntava-se como reconhecer que um signo designava realmente o que ele significava; a partir do século XVII, perguntar-se-á como um signo pode ser ligado ao que ele significa. Questão à qual a idade clássica responderá pela análise da representação; e à qual o pensamento moderno responderá por uma análise do sentido e da significação ${ }^{27}$. (MC, p. 58)

Será então em relação ao problema da natureza da ligação dos seus elementos que se formará a definição do signo no saber clássico. Ainda que, como dissemos acima, a disposição binária do signo seja, a partir da metade do século XVII, a sua "propriedade mais fundamental" e a principal diferença que se estabelece com relação a sua organização ternária, outras diferenças logo se apresentam. A começar pela própria natureza dos seus elementos: significante e significado não mais serão figuras da semelhança que se encontravam dadas no mundo, já que, doravante, o signo consistirá na "ligação estabelecida entre a ideia de uma coisa e a ideia de uma outra" (MC, p. 78). E, enquanto ligação entre duas representações (ou duas ideias), a certeza desta ligação será uma das novas variáveis que o definem: "um signo pode ser tão constante que estamos seguros de sua fidelidade (é assim que a respiração designa a vida); mas ele pode ser simplesmente provável (como a palidez para a gravidez)" (MC, p. 72). Assim, ao mesmo tempo em que o signo deixa de ter uma disposição ternária e que seus elementos deixam de ser figuras da semelhança, Foucault nota que é o próprio espaço em que ele vem se alojar que também se transforma: se, no saber da Renascença, considerava-se que Deus havia depositado os signos no mundo para que os homens pudessem vir a conhecê-los, no saber clássico, "uma vez que ele [o signo] é sempre ou certo ou provável, deve encontrar seu espaço no interior do conhecimento" (MC, p. 73, grifos meus).

$\mathrm{Na}$ Renascença, depositados no mundo, a existência dos signos era indiferente ao fato de serem ou não conhecidos, já que o conhecimento era sempre posterior à instituição deles. Como Deus marcou o mundo com assinaturas cujos significados eram preestabelecidos, havia aí "a presença implícita de um discurso prévio que era preciso restituir para trazer à luz o sentido autóctone das coisas" (MC, p. 80). Pode-se dizer,

\footnotetext{
${ }^{27}$ Ao apontar a precedência da transformação da natureza do signo em relação a essa nova questão, Foucault inverte a formulação de Ortigues, para quem, "esta ligeira variação provém, sem dúvida, de que a fórmula não preencheu sempre a mesma função, não serviu sempre para resolver o mesmo gênero de problemas." - Edmond Ortigues. Le discours et le symbole. Paris: Beauchesne, 2007, p. 81.
} 
então, que a "motivação" dos signos era divina, e, por isso, o modo de conhecê-los não podia ser outro que divinatio ${ }^{28}$ : decifrar, interpretar as marcas visíveis a fim de descobrir seus significados, as semelhanças ocultas, que lhes pertenciam desde sempre, à revelia do ato de interpretá-las. Como diz Foucault: "esta descoberta nada mais era que o fim último dos signos, a justificação da sua presença; era sua utilização possível e, sem dúvida, a melhor; mas eles não tinham necessidade de ser conhecidos para existir" (MC, p. 73, grifos meus). As coisas eram tramadas e conhecidas pela rede de semelhanças marcantes e marcadas, mas silenciosas:

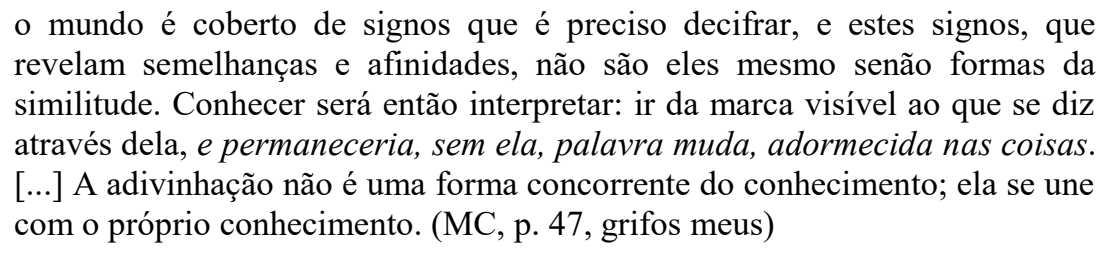

Como diz Foucault diversas vezes, na Renascença, interpretar era "fazer falar" (Cf., p. ex., MC, pp. 48, 93) os signos dados de antemão no mundo. É, pois, em contraposição a esta sua anterioridade e exterioridade que podemos compreender o seu recolhimento no espaço do conhecimento, na interioridade do pensamento. No saber clássico, a constituição dos signos passará a ser coetânea do ato de conhecimento; por isso, não haverá mais signos que sejam "silenciosos" ou desconhecidos:

não que os homens estejam em posse de todos os signos possíveis. Mas que não há signo senão a partir do momento em que se acha conhecida a possibilidade de uma relação de substituição entre dois elementos já conhecidos. O signo não espera silenciosamente a vinda daquele que pode reconhecê-lo: ele só se constitui por um ato de conhecimento. [...] E se Deus ainda utiliza signos para nos falar através da natureza, ele se serve de nosso conhecimento e das ligações que se estabelecem entre as impressões para instaurar em nosso espírito uma relação de significação. (MC, p. 73, grifos meus)

Através da descrição desta diferença, já podemos perceber que a análise de Foucault atribui uma posição fundamental, primeira, ao sistema dos signos. Isso aparece de maneira suficientemente clara a partir do que acabamos de dizer sobre o saber da Renascença. Aí, a anterioridade dos signos em relação ao conhecimento não era apenas, digamos, cronológica, mas, também, arqueológica, na medida em que a forma do conhecimento no saber desta época se justificava pela natureza dos signos: se estes eram assinaturas cujos significados estavam preestabelecidos, logo, o modo do conhecimento só podia ser a interpretação, isto é, reconhecer e decifrar semelhanças visíveis que

\footnotetext{
${ }^{28} \mathrm{O}$ conhecimento "tinha por tarefa levantar uma linguagem prévia distribuída por Deus no mundo; é neste sentido que, por uma implicação essencial, ele adivinhava, e ele adivinhava o divino." - MC, p. 73.
} 
indicavam outras semelhanças invisíveis. Em suma, a semelhança era a "categoria fundamental" do saber da Renascença, pois, ao nível arqueológico, a natureza do signo fazia dela a forma e o conteúdo do conhecimento:

Forma marcante [signante] e forma marcada [signée] são semelhanças, mas oblíquas. E é por isso, sem dúvida, que a semelhança no saber do século XVI é o que há de mais universal; ao mesmo tempo, o que há de mais visível, mas que se deve, entretanto, buscar descobrir, pois é a mais oculta; o que determina a forma do conhecimento (pois não se conhece senão seguindo os caminhos da similitude), e o que lhe garante a riqueza do seu conteúdo (pois, desde que se apanha os signos e que se olha o que eles indicam, deixa-se vir às claras e cintilar na sua própria luz a própria Semelhança). (MC, p. 44, grifos meus)

No saber clássico essa posição fundamental do sistema dos signos se mantém. E isso toca numa questão metodológica que cabe tratar aqui, pois ela esclarece o que é o nível arqueológico deste saber. Foucault o designa na seguinte passagem - que avança alguns temas sobre os quais trataremos mais à frente:

pode-se definir [...] os instrumentos que prescrevem ao pensamento clássico o sistema dos signos. É ele que introduz no conhecimento a probabilidade, a análise e a combinatória, o arbitrário justificado do sistema. É ele que dá lugar, ao mesmo tempo, à busca da origem e a calculabilidade; à constituição de quadros fixando as composições possíveis e à restituição de uma gênese a partir dos elementos mais simples; é ele que aproxima todo saber de uma linguagem e busca substituir todas as línguas por um sistema de símbolos artificiais e de operações de natureza lógica. Ao nível de uma história das opiniões, tudo isso aparece sem dúvida como um entrecruzamento de influências, em que seria preciso, sem dúvida, fazer aparecer a parte individual que pertence a Hobbes, Berkeley, Leibniz, Condillac, aos Ideólogos. Mas, se se interroga o pensamento clássico ao nível do que arqueologicamente o tornou possível, percebe-se que a dissociação do signo e da semelhança no começo do século XVII fez aparecer essas figuras novas que são a probabilidade, a análise, a combinatória, o sistema e a língua universal, não como temas sucessivos, engendrando-se ou rejeitando-se uns aos outros, mas como uma rede única de necessidades. E foi ela que tornou possível essas individualidades a que chamamos Hobbes, ou Berkeley, ou Hume, ou Condillac. (MC, p. 77, grifos meus)

Vimos na seção anterior que a descontinuidade entre a ordem clássica e a ordem renascentista se instaurava quando a semelhança deixava de ser uma "categoria fundamental" do saber. Esta transformação, Foucault já a identificava nas Regras de Descartes, ou seja, aí o arqueólogo já encontrava o saber clássico excluindo a semelhança para as suas margens, apontando-a como aquilo que deve ser analisado (cf. MC, p. 66), uma vez que ela é "a forma mais simples sob a qual aparece o que se deve conhecer e que está mais afastado do próprio conhecimento" (MC, p. 82). No entanto, ao nível arqueológico, é pela “dissociação do signo e da semelhança”, isto é, quando a disposição do signo deixa de ser ternária e passa a ser binária, que se realiza esta 
exclusão. Como diz Foucault na passagem acima, é esta transformação da natureza do signo que "tornou possível" o pensamento clássico (que inclui o pensamento de Descartes) e que "fez aparecer", inclusive, a análise como modo privilegiado de conhecimento em detrimento da interpretação ${ }^{29}$.

$\mathrm{Na}$ Renascença e na idade clássica, o nível arqueológico do saber coincide com o sistema dos signos e com a natureza deles em cada uma dessas épocas ${ }^{30}$. Nesse sentido, na perspectiva da análise arqueológica do saber clássico, a contraparte inseparável da crítica da semelhança que já aparece nas Regras se encontra na transformação da natureza do signo que Foucault identifica na Lógica de Port-Royal. Embora a Lógica seja uma obra cartesiana e cronologicamente posterior às Regras, Foucault as analisa a partir de uma perspectiva sincrônica; quer dizer, suspendendo metodologicamente o constrangimento de categorias de análise como as de "autor", "influência" etc., mostra que, sob a crítica da semelhança que aparece na segunda, encontra-se a transformação da natureza do signo da qual a primeira dá o maior testemunho. Assim, na medida em que o signo passa a ser a binário, isto é, que os seus elementos e a ligação entre eles deixam de ser semelhanças, estas são excluídas do conhecimento e, com isso, instaura-se uma descontinuidade entre as ordens do saber renascentista e do saber clássico. Como afirma Fraçois Wahl:

a epistémê, como toda ordem, envolve uma semiologia. Proposição que já dá o instrumento adequado para distinguir dois modos de transformação da ordem: a reorganização de setores no interior de uma classificação intocada no seu conjunto, o que se poderia chamar de retoque epistemológico (Foucault diria que se permanece no interior de uma mesma epistémê); e a mudança de uma ordenação em seu principio, isto é, do próprio signo, do tipo de articulação que ele estabelece entre representante e representado. ${ }^{31}$

Seja a sua disposição ternária ou binária, o signo, em sua forma mais geral, como diz Roland Barthes, é "uma relação entre dois relata"32. Assim, no século XVII, quando ele deixa de ter uma disposição ternária e assume uma disposição binária, o que se transforma não é apenas a natureza dos dois relata (que de figuras da semelhança passam a ser ideias ou representações) e o espaço em que eles se encontram (deixam de habitar o mundo para se recolherem no espaço do conhecimento), mas, sobretudo, a

\footnotetext{
${ }^{29}$ Voltaremos a este ponto mais à frente.

${ }^{30}$ Poderemos ver no capítulo 2 que o mesmo não acontece no saber moderno.

${ }^{31}$ François Wahl. "Há uma epistemê estruturalista? Ou de uma filosofia aquém do estruturalismo: Michel Foucault". In: Estruturalismo e filosofia. São Paulo: Editora Cultrix, s.d., p. 17. - O que Wahl chama de "retoque epistemológico" é tratado por Foucault na maior parte do capítulo "Os limites da representação", "retoques" que ainda não chegam a instaurar uma descontinuidade entre duas ordens do saber - no caso, entre a clássica e a moderna.

${ }^{32}$ Roland Barthes. L'aventure sémiologique. Paris: Éditions du Seuil, 1985, p. 36.
} 
forma da relação que os liga - ou, nos termos de Wahl, o "tipo de articulação" que eles estabelecem. Em suma, transforma-se a própria relação de significação, aquilo mesmo que possibilita que um signo signifique alguma coisa. Vimos que, se na Renascença o signo era ternário, era porque uma figura intermediária da semelhança estabelecia essa relação: ela elevava uma assinatura à condição de significante ao mesmo tempo em que era a cifra da figura da semelhança oculta designada. Ora, quando o signo assume uma disposição binária, deixando de ter um elemento intermediário que liga o significante e o significado, qual será a forma da relação que possibilita a ligação dos dois relata?

Como dizia Foucault numa passagem que citamos acima, o saber clássico responderá a esse problema através de uma "análise da representação". Quando se fala de uma "teoria dos signos" nesta época, é certo que ela não se limita a tratar dos signos verbais, mas de toda representação que pode ser tomada "em seu ser simples de ideia, ou de imagem ou de percepção, associada ou substituída a uma outra” (MC, p. 78), sejam elas "gestos, pantomima, versões, pinturas, emblemas" (MC, p. 97); em suma, toda representação que porte a ligação a uma outra. Todavia, esta representação significante está sujeita a uma condição para que ela seja considerada um signo e para que este seja uma "pura dualidade" (MC, p. 78). Esta condição é a de que o significante se duplique, quer dizer, ele deve "manifestar [...] a relação que o liga ao que ele significa. É preciso que ele represente, mas que esta representação, por sua vez, encontre-se representada nele" (MC, p. 78).

Deste modo, a problemática da teoria dual do signo recai sobre o elemento significante. Foucault mesmo avança uma possível objeção e nota que a necessidade da representação de representar a sua representatividade, para que possa ser considerada um signo, poderia nos levar a pensar que a sua natureza é ternária, e não binária; poderse-ia objetar que a duplicação da representação significante, na verdade, introduziria uma representação intermediadora (“a ideia do seu papel de representação" (MC, p. 78)) que a ligaria à representação significada. Porém, o filósofo salienta que não é disso que se trata, que a duplicação da representação é, antes, "um deslocamento inevitável da figura de dois termos, que recua em relação a ela mesma e vem se alojar inteiramente no interior do elemento significante" (MC, p. 78). Como compreender esse "deslocamento" e esse "recuo", já que eles parecem ser a chave para elucidar o que é a significação no saber clássico? Neste caso, o melhor é nos voltarmos para próprio texto da Lógica de Port-Royal, donde Foucault extrai algumas passagens citadas em As palavras e as coisas: 
Quando se considera um objeto em si mesmo e em seu próprio ser, sem levar o olhar do espírito àquilo que ele pode representar, a ideia que se tem dele é uma ideia de coisa, como a ideia da terra, do sol; mas quando só se olha um certo objeto como representando um outro, a ideia que se tem dele é uma ideia de signo, e este primeiro objeto se chama signo. É assim que, em geral, olhamos os mapas e os quadros. Assim, o signo encerra duas ideias: uma da coisa que representa, outra da coisa representada, e sua natureza consiste em excitar a segunda pela primeira. ${ }^{33}$

Em vista disso, primeiramente, procuremos não confundir a relação de denotação ${ }^{34}$, enquanto a relação da ideia do signo com a ideia da coisa que ele significa (o seu "referente"), com a relação das duas ideias que o signo necessariamente encerra (a representação significante $e$ a representação do significado), constituindo uma unidade. O problema da significação concerne a esta última relação, ele diz respeito à relação das duas ideias que compõe o signo, e que consiste na "operação" que permite a ideia deste substituir-se à ideia da coisa significada. Foucault diz o fundamental sobre essa relação, na seguinte passagem:

Uma ideia pode ser signo de uma outra não somente porque entre elas pode se estabelecer um vínculo de representação, mas porque esta representação sempre pode se representar no interior da ideia que representa. Ou ainda porque, em sua essência própria, a representação é sempre perpendicular a ela mesma: ela é ao mesmo tempo indicação e mostrar-se [apparaître]; relação a um objeto e manifestação de si. A partir da idade clássica, o signo é a representatividade da representação na medida em que ela é representável. (MC, p. 79, grifo "em sua essência própria")

De fato, se a duplicação da representação não introduz um terceiro termo entre o significante e o significado, distinguindo desta maneira a relação de significação na idade clássica, Foucault parece atribuir, em detrimento do significado, um privilégio ao elemento significante, que manifestaria por si mesmo seu "poder representativo" (MC, p. 78). Todavia, isso é apenas uma aparência, já que, “com efeito, o significante têm como todo seu conteúdo, toda sua função e toda sua determinação somente o que ele representa: ele lhe é inteiramente ordenado e transparente" (MC, p. 78). E, por isso, "na

\footnotetext{
${ }^{33}$ Antoine Arnauld, Pierre Nicole. La logique ou l'art de penser. Paris: Éditions Gallimard, 1992, p.46. É útil notar que, em As palavras e as coisas, o fim da citação deste trecho da Lógica de Port-Royal encontra-se invertido. Lemos aí: ““...consiste em excitar a primeira pela segunda”” (MC, p. 78).

${ }^{34}$ Existem "relações semelhantes e, todavia, diferentes que são habitualmente confundidas sob o nome de 'significação' ou de 'signo'. Assim, distinguir-se-á cuidadosamente (como, aliás, fizeram-no quase todos os teóricos do signo) a significação da função referencial (às vezes chamada de denotação). A denotação se produz não entre um significante e um significado, mas entre o signo e o referente, ou seja, no caso mais fácil de imaginar, um objeto real: não é mais a sequência sonora ou gráfica 'maçã' que se liga ao sentido maçã , mas a palavra (: o próprio signo) 'maçã' às maçãs reais. [...] [A denotação] é muito menos frequente que se crê: falamos das coisas em sua ausência antes que em sua presença; ao mesmo tempo, é difícil conceber qual seria o 'referente' da maior parte dos signos." - Oswald Ducrot, Tzvetan Todorov. Dictionnaire encyclopédique des sciences du langage. Paris: Éditions du Seuil, 1972, p. 133.
} 
idade clássica, a ciência pura dos signos vale como o discurso imediato do significado" (MC, p. 81, grifo meu).

Foucault voltará a tratar da teoria clássica do signo na "Introdução" que ele escreve para a Gramática geral e razoada de Arnauld e Lancelot. Neste texto, ele observa que, na Lógica de Port-Royal, a teoria dos signos "faz parte da análise das relações da ideia ao seu objeto" (DE I, 60, pp. 771). Pautando-se por essa relação pensando o signo como a relação de duas ideias e seus respectivos objetos -, ele afirma: “dar um signo para uma ideia é dar-se uma ideia cujo objeto será o representante do que constituía o objeto da primeira ideia; o objeto do signo será substituível e equivalente à ideia do objeto significado" ${ }^{\prime 35}$ (DE I, 60, p. 771). Noutras palavras, é porque o objeto de uma ideia é representado como o "duplo" equivalente do objeto de outra ideia, que aquela é considerada um signo; no entanto, "este conteúdo só é indicado numa representação que se dá como tal, e o significado se aloja sem resíduo nem opacidade no interior da representação do signo" (MC, p. 78, grifos meus). Neste sentido, Foucault lembra que, se, na Lógica de Port-Royal, o quadro ou o mapa são exemplos privilegiados do que é um signo, é porque ele "tem por conteúdo somente o que ele representa, e todavia esse conteúdo só aparece representado por uma representação" (MC, p. 79). Por exemplo, diante do retrato de um rei, a ideia sensível (significante) que temos do próprio quadro não tem por objeto os seus elementos (molduras, tela, tintas, linhas, cores, etc.), o que seria apenas a ideia de uma coisa (a ideia de um quadro); ela tem por objeto (significado, conteúdo) a representação do objeto da ideia do rei em pessoa. O quadro é um signo (significante $e$ significado) não porque a sua representatividade seja dada por uma ideia intermediária, que seria a "ideia da representatividade do quadro" (que elevaria este à condição de significante); ela é a representatividade imediata da representação do rei (do próprio significado, do conteúdo), que se dá como representação do objeto da ideia do rei em pessoa ${ }^{36}$. Não se

\footnotetext{
${ }^{35}$ Foucault representa esta disposição do signo da seguinte maneira: "Ideia $\rightarrow$ (objeto $=$ ideia $\rightarrow$ ) objeto" (DE I, 60, p. 771).

${ }^{36} \mathrm{Na}$ relação de significação clássica, o elemento significante deve ser transparente em proveito da manifestação do significado. Isto é o que parece dizer a seguinte passagem da Lógica de Port-Royal: "Se se objetar que, ao mesmo tempo em que nós temos a ideia de coisas espirituais como do pensamento, nós não deixamos de formar alguma imagem corporal, ao menos do som que o significa, não se dirá nada de contrário ao que provamos; pois essa imagem do som de pensamento que imaginamos, não é a imagem do próprio pensamento, mas somente de um som; e ela não pode servir para fazer concebê-lo senão na medida em que a alma, sendo acostumada, quando ela concebe este som, a conceber também o pensamento, se forma ao mesmo tempo uma ideia inteiramente espiritual do pensamento, que não tem nenhuma relação com o som, mas que somente é ligada aí pelo hábito [accoutumance]" - Antoine
} 
trata então de um mero jogo de palavras: a representação da representatividade da representação é, simplesmente, o objeto de uma ideia que se dá como a representação do objeto de uma outra ideia. Deste modo, a "relação" que liga os dois relata é manifestada no signo como esta "relação de objeto duplicado que é a significação" (DE I, 60, pp. 775).

Como se vê, voltando-se para a Lógica de Port-Royal, na qual se apresenta da maneira mais clara essa transformação da disposição do signo, Foucault extrai um elemento fundamental para a sua análise do saber clássico. Ele mostra que esta forma da relação de significação característica da natureza do signo nesta época é o que define, ao mesmo tempo, a "essência própria" da representação no saber clássico, o "poder próprio da representação de se representar a si mesma" (MC, p. 80). Segundo Foucault, a teoria clássica do signo "determina a dependência da relação de significação à relação de objeto e o direito da primeira de representar todas as possibilidades da segunda" (DE I, 60, p. 772), ou seja, "todas as possibilidades" na medida em que os signos "têm por função representar não somente todas as ideias, mas todos os caracteres distintivos das ideias" (DE I, 60, p. 770). Com isso, o filósofo estabelece a "operação" que está na base do "primado da representação" (MC, p. 348) que vigorou nesta época; ele estabelece a propriedade da representação que a constitui, de um ponto de vista arqueológico, como um espaço autônomo, cujos limites são os limites do próprio saber:

\footnotetext{
na idade clássica, nada é dado que não seja dado à representação; mas, por isso mesmo, nenhum signo surge, nenhuma fala se enuncia, nenhuma palavra ou nenhuma proposição jamais visa um conteúdo se não é por um jogo de uma representação que se coloca à distância de si, duplica-se e se reflete em uma outra representação que lhe é equivalente. As representações não se enraízam num mundo do qual elas tomam de empréstimo seu sentido; elas se abrem a partir de si mesmas sobre um espaço que lhes é próprio, e cuja nervura interna dá lugar ao sentido (MC, p. 92)
}

\subsection{A dissolução da linguagem em um "puro funcionamento": o Discurso}

A relação de significação, tomada como uma "operação" intrínseca à ideia do signo, é o que funda a autonomia da representação no saber clássico, uma vez que aí, como afirma Sabot, "a instauração da relação representativa às coisas [...] se exprime de

Arnauld e Pierre Nicole. La logique ou l'art de penser. Paris: Éditions Gallimard, 1992, pp. 39-40, grifos meus. 
maneira autônoma no próprio signo" ${ }^{37}$. Como vimos, se na Renascença os signos "habitavam" o mundo e eram "meios de conhecer e chaves para um saber" (MC, p. 79), na idade clássica, desertando-o, eles passam a cobrir todo o espaço da representação do mundo, de modo que conhecê-los será conhecer o mundo nos limites desse espaço. Nas palavras de Foucault: "os fenômenos jamais são dados senão numa representação que, em si mesma, e pela sua representabilidade própria, é inteiramente signo" (MC, p. 80, grifos meus). Assim, se a significação concerne à relação entre os elementos que compõem um signo (significante e significado), a "nervura interna" do espaço da representação será articulada pelas relações dos signos entre si, isto é, por um sistema dos signos que "dá lugar ao sentido":

\begin{abstract}
os signos não têm outras leis que aquelas que podem reger seu conteúdo: toda análise dos signos é, ao mesmo tempo, e de pleno direito, decifração do que eles querem dizer. Inversamente, trazer à tona o significado não será nada mais que a reflexão sobre os signos que o indicam. [...] Não haverá então uma teoria dos signos diferente de uma análise do sentido. No entanto, o sistema atribui um certo privilégio à primeira sobre a segunda; já que ela [a teoria dos signos] não dá ao que é significado uma natureza diferente daquela que ela atribui ao signo, o sentido não poderá ser mais que a totalidade dos signos desdobrada em seu encadeamento; ele se dará no quadro completo dos signos. Mas, por outro lado, a rede completa dos signos se liga e se articula segundo os cortes próprios do sentido. O quadro dos signos será a imagem das coisas. (MC, p. 80).
\end{abstract}

Os signos, como diz Foucault, "atravessam todo o domínio da representação empírica, mas jamais a transbordam" (MC, p. 87, grifos meus). Neste domínio predomina uma completa transparência e coordenação entre a representação e o que nela é dado, uma vez que "entre o signo e seu conteúdo não há nenhum elemento intermediário e nenhuma opacidade" (MC, p. 80). É neste domínio que veremos a linguagem clássica, o Discurso, fundir-se com a representação e com o conhecimento; é aí, portanto, que a veremos desempenhar o papel que lhe é próprio no saber clássico:

neste papel, a linguagem transforma a sequência de percepções em quadro, e, inversamente, recorta o contínuo dos seres em caracteres. Aí onde há discurso, as representações se repartem e se justapõem; as coisas se assemelham e se articulam. A vocação profunda da linguagem clássica sempre foi a de constituir "quadro": seja como discurso natural, recolhimento da verdade, descrição das coisas, corpus de conhecimentos exatos ou dicionário enciclopédico. (MC, p. 322)

Para que possamos, então, compreender o modo de ser da linguagem clássica e esse papel que ela desempenha no saber, na medida em que ela se funde com a representação e com o conhecimento, faz-se necessário que retornemos, mais uma vez,

\footnotetext{
${ }^{37}$ Philippe Sabot. Le Même et l'Ordre - Michel Foucault et le savoir à l'âge classique. Lyon: ENS Éditions, 2015, p. 75.
} 
às análises do saber da Renascença. Isto porque, através das diferenças com o modo de ser da linguagem nesta época, pode-se esclarecer por que a linguagem clássica se define como Discurso.

Vimos anteriormente como Foucault descrevia a natureza do signo na Renascença. Mas não haveria nesta época, no interior do seu sistema dos signos, uma diferenciação entre aqueles que são naturais e aqueles que são instituídos, como a linguagem? Com efeito, esta diferença entre os signos naturais e aqueles que se sabe ${ }^{38}$ que são signos de instituição é apenas superficial, pois, nesta época, as palavras são coisas da mesma maneira que os signos naturais também são. Estes como aquelas fazem parte do mesmo jogo das semelhanças ocultas e das marcas visíveis:

Em seu ser bruto e histórico do século XVI, a linguagem não é um sistema arbitrário; está depositada no mundo e faz parte dele porque, ao mesmo tempo, as próprias coisas escondem e manifestam seu enigma como uma linguagem e porque as palavras se propõem aos homens como coisas a decifrar $[\ldots]$.

A linguagem faz parte da grande distribuição das similitudes e das assinaturas. (MC, pp. 50-51).

Ora, esta imbricação da linguagem com todas as marcas da natureza certamente "supõe um privilégio absoluto da escrita", que, segundo Foucault, foi "um dos grandes acontecimentos da cultura ocidental" (MC, p. 53):

\begin{abstract}
a imprensa, a chegada à Europa dos manuscritos orientais; o aparecimento de uma literatura que não era mais feita para a voz ou para a representação, nem comandada por elas; a primazia dada à interpretação dos textos religiosos sobre a tradição e o magistério da Igreja - tudo isso testemunha, sem que se possa discriminar efeitos e causas, o lugar fundamental assumido, no Ocidente, pela Escrita. A linguagem tem, doravante, por natureza primeira ser escrita. Os sons da voz formam apenas a sua tradução transitória e precária. O que Deus depositou no mundo são palavras escritas; Adão, quando impôs os primeiros nomes aos animais, não fez mais que ler essas marcas visíveis e silenciosas; a Lei foi confiada a Tábuas, não à memória dos homens; e a verdadeira Palavra, é num livro que é preciso encontrá-la. (MC, p. 53)
\end{abstract}

É como escrita que a linguagem manifesta a sua existência própria na Renascença, quer dizer, a sua espessura de coisa em meio às outras coisas, tal como se apresentam os outros signos na natureza. Além disso, segundo Foucault, esse privilégio da escrita é o que explica uma das características maiores do saber do século XVI, ou seja, que aí não haja "distinção entre o que se vê e o que se lê, entre o observado e o

\footnotetext{
38 "Sabia-se desde muito tempo - e bem antes do Crátilo - que os signos podem ser dados pela natureza ou constituídos pelo homem. O século XVI também não o ignorava e reconhecia nas línguas humanas os signos de instituição. Mas os signos artificiais só deviam seu poder à sua fidelidade aos signos naturais. Estes, de longe, fundavam todos os outros." - (MC, p. 75)
} 
relatado, logo, [...] a constituição de uma camada única e lisa em que o olhar e a linguagem se entrecruzam ao infinito" (MC, p. 54). No conhecimento de um animal qualquer, por exemplo, tudo entra, tudo é igualmente assimilado, desde o que se pode observar da sua anatomia, dos seus movimentos, dos seus hábitos, até o que dele foi relatado em histórias, lendas, fábulas, etc. ${ }^{39}$. Não é o caso, porém, de se denunciar aí uma falta de rigor científico, de dizer que a ciência desta época "seria o lugar liberal de uma confrontação entre a fidelidade aos Antigos, o gosto pelo maravilhoso e uma atenção já despertada para esta soberana racionalidade na qual nós nos reconhecemos" (MC, p. 47). Trata-se, antes, de reconhecer, de um ponto de vista arqueológico, que no saber renascentista, tomado em sua especificidade, "a natureza, em si mesma, é um tecido ininterrupto de palavras e de marcas, de narrativas e de caracteres, de discursos e de formas" (MC, p. 55, grifo meu). A natureza "era, inteiramente, escrita" (MC, p. 55) e a escrita, "somente ela detém a verdade" (MC, p. 54).

Esse tecido de escrita, no entanto, estende-se sobre uma espécie de desarticulação ancestral da linguagem, já que esta não é mais a mesma que Deus deu aos homens: uma linguagem que na "sua forma primeira [...] era um signo das coisas absolutamente certo e transparente, porque ele lhes assemelhava" (MC, p. 51). Esta semelhança às coisas nomeadas era imediata e foi ela "a primeira razão de ser da linguagem" (MC, p. 51) - primordialmente escrita:

\begin{abstract}
Vigenère et Duret diziam, ambos - e em termos quase idênticos - que o escrito sempre precedera o falado, certamente na natureza, talvez mesmo no saber dos homens. Pois, poderia bem ser que antes de Babel, que antes do Dilúvio, houvesse uma escrita composta das próprias marcas da natureza, de modo que esses caracteres teriam tido o poder de agir diretamente sobre as coisas, de atraí-las ou de repeli-las, de figurar suas propriedades, suas virtudes e seus segredos. (MC, pp. 53-54)
\end{abstract}

Babel veio como um castigo que baralhou essa "escrita primitivamente natural" (MC, p. 54) e, dentre todas as línguas que então apareceram, apenas uma, o hebreu, conservou resquícios da "nomeação primeira" (MC, p. 51). Isto para que os homens não esquecessem tal punição, para "contar a velha aliança de Deus com seu povo [...][e]

\footnotetext{
39 "Com efeito, quando nos reportamos à Historia serpentum et draconum [de Aldrovandi], vemos o capítulo 'Da serpente em Geral' desenvolver-se segundo as seguintes rubricas: equívoco (isto é, os diferentes sentidos da palavra serpente), sinônimos e etimologias, diferenças, forma e descrição, anatomia, natureza e costumes, temperamento, coito e geração, voz, movimentos, lugares, alimentação, fisionomia, antipatia, simpatia, modos de captura, morte e ferimentos pela serpente, modos e sinais de envenenamento, remédios, epítetos, denominações, prodígios e presságios, monstros, mitologia, deuses aos quais é consagrada, apólogos, alegorias e mistérios, hieróglifos, emblemas e símbolos, adágios, moedas, milagres, enigmas, divisas, signos heráldicos, fatos históricos, sonhos, simulacros e estátuas, usos nos alimentos, usos na medicina, usos diversos. [...] Para Aldrovandi e seus contemporâneos tudo isso é legenda - coisas para ler. - (MC, pp. 54-55)
} 
para mostrar que ele foi outrora a língua comum a Deus, a Adão, e aos animais da primeira terra" (MC, p. 51)". Mas essas "similitudes radicais" (MC, p. 51) do hebreu, "monumentos fragmentários" (MC, p. 51) com uma função mnemônica, jamais poderiam fazer com que a linguagem fosse novamente "a natureza em sua visibilidade de origem” (MC, p. 51). Daí que, na Renascença, “a linguagem real [...] é coisa opaca, misteriosa, fechada sobre ela mesma, massa fragmentada e ponto por ponto enigmática, que se mistura aqui e ali com as figuras do mundo e se embaraça com elas" (MC, p. 49).

Esta desarticulação da linguagem primeira, a passagem mítica da transparência da origem à opacidade da "linguagem real" não significa, portanto, que entre esta e o mundo tenha se instaurado uma distância e, tampouco, que a escrita seja uma forma decaída. O que torna a linguagem opaca não é a falta de ligações com as coisas, mas o excesso delas. Pertencendo ao sistema dos signos sem se diferenciar dos signos naturais, há entre a "linguagem real" e o mundo, em contraposição à imediata semelhança da escrita de Deus com as coisas que ela nomeava, uma multiplicação sem fim de ligações passíveis de serem descobertas. Ligações que aparecem na forma das semelhanças, as quais se interpõem "como um terceiro" entre a assinatura e o que ela indica e que, ao mesmo tempo, permite reconhecê-la como um signo. Neste sentido, diz Foucault:

\begin{abstract}
o estudo da gramática repousa, no século XVI, sobre a mesma disposição epistemológica que a ciência da natureza ou as disciplinas esotéricas. Únicas diferenças: há uma natureza e várias línguas; e, no esoterismo, as propriedades das palavras, das sílabas e das letras são descobertas por um outro discurso que, ele mesmo, permanece secreto, enquanto, na gramática, são as palavras e as frases de todos os dias que enunciam por elas mesmas suas propriedades. A linguagem está a meio caminho entre as figuras visíveis da natureza e as conveniências secretas dos discursos esotéricos. É uma natureza fragmentada, dividida contra ela mesma e alterada, que perdeu sua transparência primeira; é um segredo que carrega consigo, mas na superfície, as marcas decifráveis do que ela quer dizer. Ela é, ao mesmo tempo, revelação escondida e revelação que pouco a pouco se restitui numa claridade ascendente. (MC, pp. 50-51, grifos meus)
\end{abstract}

Não há, pois, um corte que separaria os signos - logo, a linguagem - e as coisas. O que Foucault descreve, de um ponto de vista arqueológico, como motivo da opacidade da linguagem, e sob o mito da perda da transparência originária das palavras, não é senão aquele "pequeno deslocamento", aquela diferença na "lei de distribuição" do círculo das assinaturas em relação ao círculo das outras semelhanças. E nesta configuração, como "marcas decifráveis", a existência da linguagem como uma coisa vem se afirmar através das próprias "formas [de conhecimento] requisitadas" (MC, p. 47) pelo saber da Renascença, isto é, divinatio, mas também eruditio: 
não há diferença entre estas marcas visíveis que Deus depositou sobre a superfície da terra para nos fazer conhecer os seus segredos interiores e as palavras legíveis que a Escritura, ou os sábios da Antiguidade, que foram esclarecidos por uma luz divina, depositaram nestes livros que a tradição salvou. A relação aos textos [eruditio] é da mesma natureza que a relação às coisas [divinatio]; aqui e ali, são signos que arrolamos. [...] A herança da Antiguidade é como a própria natureza, um vasto espaço para interpretar; aqui e ali, é preciso arrolar signos e pouco a pouco fazê-los falar. (MC, p. 48)

Tal como a linguagem na Renascença, o modo de ser da linguagem clássica está em correlação com a teoria clássica dos signos em geral. Assim, se a primeira característica desta linguagem que Foucault descreve, como vimos no início desta seção, diz respeito a sua identidade com o pensamento, na medida em que as palavras recebem "a tarefa e o poder" (MC, p. 92) de representá-lo, esta identidade pode ser entendida a partir do movimento dos signos em geral; ou seja, o movimento pelo qual eles deixam de "habitar" o mundo para se alojarem "no interior da representação, no interstício da ideia, neste tênue espaço em que ela joga com ela mesma, decompondo-se e recompondo-se" (MC, p. 81, grifos meus). Deixando de se misturar com todos os signos naturais que o saber da Renascença procurava interpretar, a linguagem clássica vem se identificar com o pensamento como aquilo que, representando as representações, permite que estas fundem no seu próprio espaço o jogo de suas análises e de suas sínteses. A linguagem no saber clássico, como diz Foucault:

\footnotetext{
perdeu aquela consistência secreta que, no século XVI, dava-lhe a densidade de uma palavra a decifrar e a imbricava com as coisas do mundo [...]: na idade clássica, o discurso é esta necessidade translúcida através da qual passam a representação e os seres - quando os seres são representados ao olhar do espírito, quando a representação torna visíveis os seres em sua verdade. (MC, p. 322)
}

Esta função de crivo que analisa as representações, desempenhada pela linguagem, justifica-se, portanto, pela transformação da natureza dos signos a partir do século XVII. Como vimos, no século XVI, a ligação das assinaturas com os seus significados, isto é, com as semelhanças ocultas que elas indicavam, era feita por uma terceira figura da semelhança. Mas esta, além de ligar uma assinatura ao seu conteúdo, era o que também tornava possível que uma assinatura fosse reconhecida como tal, na medida em que ela era a forma pela qual esta última se fazia visível. Este reconhecimento, no entanto, não podia ser imediato, pois, sendo esta figura intermediária da mesma natureza do conteúdo que ela indicava, uma semelhança encontrada poderia ser tanto uma marca quanto o que é marcado, de modo que reconhecer uma semelhança como uma assinatura exigia que ela, antes, fosse 
interpretada. Assim, como as assinaturas podiam assumir a forma de qualquer uma das outras quatro figuras que compõem o sistema das semelhanças no saber da Renascença, este saber "se condenava" a uma interpretação sem fim. Como diz Foucault:

colocando como ligação, entre o signo e o que ele indica, a semelhança (ao mesmo tempo terceira potência e poder único, já que ela habita do mesmo modo a marca e o conteúdo), o saber do século XVI se condenou a só conhecer sempre a mesma coisa, mas a conhecê-la somente ao termo jamais alcançado de um percurso indefinido. (MC, p. 45)

Assim, os signos sempre "queriam dizer" mais do que uma interpretação era capaz de revelar. As coisas $e$ as palavras, fazendo parte da mesma maneira do círculo das assinaturas, tinham como significados uma rede de semelhanças ocultas que formava um "discurso prévio", um "Texto primeiro [...] aderido ao mundo" (MC, p. 56). Mas como as ligações, preestabelecidas por Deus, entre as assinaturas e os seus significados eram feitas por semelhanças, o sentido desse Texto jamais se dava por completo nas marcas (naturais ou escritas) que o indicavam: ele as transbordava, o que levava sempre adiante a tarefa da interpretação de compreendê-lo em sua totalidade.

A função analítica dos signos a partir do século XVII aparece justamente em contraposição a esta característica que eles possuíam no saber renascentista, isto é, que, em relação ao conhecimento que deles se podia ter, os seus significados eram dados de antemão e se mantinham ainda como um fundo inesgotável para interpretações futuras. A partir da Lógica de Port-Royal, uma transformação radical se dará neste sentido. Como diz Foucault, "para que o signo, com efeito, seja o que é, é preciso que ele seja dado ao conhecimento ao mesmo tempo que aquilo que ele significa" (MC, p. 74, grifos meus). Ou seja, em relação ao conhecimento, o significado deixa de ser algo dado anteriormente e deixa de possuir um caráter pletórico: no saber clássico, quando os signos se recolhem na interioridade do pensamento, a sua constituição, além de ser coetânea do ato de conhecimento, requer, como diz Wahl, que eles sejam dados na "plenitude do seu conteúdo" 40 . Assim, o signo e o que ele significa devem ser conhecidos e ambos devem ser representados ao mesmo tempo, "pelo menos uma vez" (MC, p. 74). Mas, para que um elemento de uma representação possa se constituir como um signo, é preciso que ele seja considerado como um elemento; é preciso que, na representação simultânea do elemento marcante e do elemento marcado, o primeiro seja distinguido do segundo. Por exemplo, no todo formado pela representação sensível do

\footnotetext{
${ }^{40}$ François Wahl. "Há uma epistemê estruturalista? Ou de uma filosofia aquém do estruturalismo: Michel Foucault". In: Estruturalismo e filosofia. São Paulo: Editora Cultrix, s.d., p. 36.
} 
som de uma palavra e da coisa que ela significa, dados conjuntamente "pelo menos uma vez", o primeiro se constitui como um signo somente quando o espírito o diferencia da segunda (cf. MC, pp. 74-75). Por isso, diz Foucault:

a constituição do signo é [...] inseparável da análise. Ele é o resultado desta, já que, sem ela, não poderia aparecer. Ele é também o seu instrumento, já que, uma vez definido e isolado, pode ser reportado para novas impressões; e aí, ele desempenha em relação a elas como que o papel de um crivo. Porque o espírito analisa, o signo aparece. Porque o espírito dispõe de signos, a análise não cessa de se prosseguir. (MC, p. 75)

Aqui reencontramos aquele traço característico das análises do saber clássico, sobre a qual falamos um pouco, anteriormente. Segundo Foucault, neste saber, "todas as representações são ligadas entre si como signos; todas elas formam como que uma imensa rede; cada uma na sua transparência se dá como o signo do que ela representa" (MC, p. 80). Assim, ao nível arqueológico, a transformação integral da natureza do signo, a partir do século XVII, é o que faz com que o conhecimento deixe de consistir num ato de decifração e passe a se desdobrar num movimento analítico pelo qual "pensar uma ideia é pensar outra" 41 . Os signos não serão mais encarregados, como eram no saber da Renascença, de ligar todas as coisas: "pelo jogo da conveniência, da emulação e, sobretudo, da simpatia, a similitude no século XVI triunfava do espaço e do tempo: pois era próprio do signo trazer e reunir" (MC, p. 74). A transformação da sua natureza prescreverá ao saber clássico um novo jogo, aquele pelo qual o espírito, por meio dos signos, passará a analisar e ordenar as representações das coisas:

a atividade do espírito [...] não consistirá mais então em aproximar as coisas entre si, em partir em busca de tudo o que nelas possa revelar como que um parentesco, uma atração ou uma natureza secretamente partilhada, mas, ao contrário, em discernir: [...] dar-se pela intuição uma representação distinta das coisas e apreender claramente a passagem necessária de um elemento da série àquele que lhe sucede imediatamente. (MC, p. 69)

Nesse jogo, a linguagem aparece como o principal jogador. Mas o que diferenciaria os signos verbais, fazendo-os desempenhar, "melhor que todos os outros", este papel de "assinalar a representação, analisá-la e recompô-la" (MC, p. 96)? Como diz Foucault:

o que distingue a linguagem de todos os outros signos, e lhe permite desempenhar na representação um papel decisivo, não é [...] tanto que ela seja individual ou coletiva, natural ou arbitrária. Mas que ela analisa a representação segundo uma ordem necessariamente sucessiva: os sons, com efeito, só podem ser articulados um a um; a linguagem não pode representar o pensamento, logo de saída, em sua totalidade; é preciso que ela o disponha

\footnotetext{
${ }^{41}$ Idem, p. 37.
} 
parte por parte segundo uma ordem linear. Ora, esta é estranha à representação. (MC, p. 96)

Ainda que as representações sejam submetidas a um desdobramento temporal, "cada uma forma uma unidade" (MC, p. 96). No entanto, os elementos que compõem essas unidades são dados de uma maneira tão comprimida que o espírito só é capaz de apreendê-los simultaneamente. São essas unidades "cerradas em si mesmas que é preciso estender nas proposições” (MC, p. 96). Em vista disso, Foucault irá diferenciar a tríade representação-signos-linguagem, colocando cada um dos seus termos em um nível distinto sem, com isso, desfazê-la. Ele apontará o que distingue a linguagem da representação - "da qual ela não é, todavia, e por sua vez, senão a representação" (MC, p. 97) - mas, também, dos outros signos - “aos quais ela pertence sem outro privilégio particular" (MC, p. 97). Quer dizer, a linguagem "não se opõe ao pensamento como o exterior ao interior, ou a expressão à reflexão; ela não se opõe aos outros signos [...] como o arbitrário ou o coletivo ao natural e ao singular. Mas a tudo isso como o sucessivo ao contemporâneo" (MC, p. 97). O Discurso, assim, é uma análise da simultaneidade dos elementos das representações numa "sequência de signos verbais" (MC, p. 97):

[a linguagem] está para o pensamento e para os signos como a álgebra está para a geometria: ela substitui a comparação simultânea das partes (ou das grandezas) por uma ordem cujos graus se deve percorrer uns após os outros. É neste sentido estrito que a linguagem é análise do pensamento: não simples divisão, mas instauração profunda da ordem no espaço. (MC, p. 97)

O "privilégio particular" da linguagem consiste, portanto, num refinamento da análise que é, como vimos acima, inseparável da própria constituição do signos em geral. Se estes só podem se constituir quando, numa representação simultânea do elemento marcante e do elemento marcado, o primeiro é distinguido do segundo; e se, assim, o espírito passa a dispor dos "instrumentos" necessários para que a análise não deixe de prosseguir; na medida em que ele dispõe de signos verbais; o movimento da análise pode desdobrar gradualmente os elementos de uma representação complexa numa ordem sucessiva. Apresentando-nos um exemplo simples disso, Foucault afirma: “para o meu olhar, 'o fulgor é interior à rosa'; no meu discurso, não posso evitar que ele a preceda ou a suceda" (MC, p. 96). Deste modo, como diz Jean-Michel Salanskis: "Foucault destaca, com efeito, uma nova determinação essencial para a representação 
clássica - essencial para ela e aos seus próprio olhos - que é a sucessividade do seu regime, o regime da representação se igualando neste caso àquele do discurso ${ }^{, 42}$.

Ora, de que maneira a linguagem instaura esse regime de sucessividade quando ela analisa a simultaneidade da representação? Para Foucault, o Discurso desempenha este papel nomeando os elementos da representação:

\begin{abstract}
Nomear é, ao mesmo tempo, dar a representação verbal de uma representação e colocá-la num quadro geral. [...][No nome] se cruzam todas as funções ${ }^{43}$ da linguagem, já que é através dele que as representações podem vir a figurar numa proposição. É então por ele também que o discurso articula-se com o conhecimento. (MC, p. 132)
\end{abstract}

Descrevendo o papel analítico do Discurso como ordenamento sucessivo e gradual dos elementos das representações complexas, Foucault mostra como ele é o “instrumento" privilegiado através do qual, no saber clássico, os conhecimentos que não se valem do cálculo mantiveram uma relação à mathesis. Como dissemos na primeira seção, Foucault atribui a esta relação um valor de regra arqueológica que se estende ao conjunto do saber clássico. E aqui podemos ver que essa regra não consiste num mero "dever ser" ou numa prescrição de um horizonte para esses conhecimentos, que teria sido fixada pela disposição anônima do saber. Se Foucault afirma que disciplinas empíricas como a gramática geral, a história natural e a análise das riquezas só puderam se constituir em relação à mathesis (cf. MC, p. 71), é na medida em que o Discurso se encontra numa "situação fundamental" em relação aos conhecimentos que elas produziram, quer dizer, na medida em que ele é o "instrumento" que desempenha um papel "inevitável" no estabelecimento de "ordens não quantitativas". Em suma, definindo o Discurso desta maneira, após ter mostrado que a mathesis pode ser entendida como uma ciência prioritariamente $d a$ ordem, a relação dos conhecimentos daquelas disciplinas a esta última pode ser descrita como uma característica efetiva desses conhecimentos, na medida em que o Discurso foi o "instrumento" do qual elas necessariamente se serviram para conhecer a ordem nos seus respectivos campos de objetos.

Assim, interessa a Foucault mostrar, sobretudo, como, na configuração geral do saber clássico, o Discurso se encontra numa "situação fundamental" em relação aos conhecimentos que formam aquilo que ele chamou de "mathesis qualitativa". Nesse

\footnotetext{
${ }^{42}$ Jean-Michel Salanskis. Herméneutique et cognition. Paris: Presses Universitaires du Septentrion, 2003, p. 49.

${ }^{43}$ Apontaremos na próxima seção quais são essas "funções".
} 
sentido, o Discurso é o que constitui neste saber "o espaço fundamental do quadro"44 (MC, p. 88). Noutras palavras, analisando e ordenando os elementos das representações, na medida em que os nomeia e os dispõe na forma de proposições, o Discurso é "a possibilidade e o princípio de uma taxinomia geral da representação” (MC, p. 132):

quando ele nomeava o ser de toda representação em geral, ele era filosofia: teoria do conhecimento e análise das ideias. Quando ele atribuía a cada coisa representada o nome que convinha e que, sobre todo o campo da representação, dispunha a rede de uma língua bem feita, ele era ciência nomenclatura e taxinomia. (MC, p. 136)

"A Renascença detinha-se diante do fato bruto de que havia linguagem: na espessura do mundo, um grafismo misturado às coisas ou correndo abaixo delas; siglas depositadas nos manuscritos ou sobre as folhas dos livros" (MC, p. 93, grifos meus). Em contraposição a esta existência de uma "coisa opaca" dotada de "propriedades" que a interpretação devia trazer à luz, Foucault descreve a transformação do seu modo de ser: "nos séculos XVII e XVIII, a existência própria da linguagem, sua velha solidez de coisa inscrita no mundo foram dissolvidas no funcionamento da representação; toda linguagem valia como discurso" (MC, p. 58). Em vista disso, podemos destacar uma outra característica do seu modo de ser no saber clássico, a saber, a sua unidade. Esta, como veremos, aparece junto com um certo privilégio da linguagem em relação às outras empiricidades: "as palavras formam um sistema de signos suficientemente privilegiado, quando se trata de fazer aparecer a ordem das coisas, para que a história natural, se ela é bem feita, e para que a moeda, se ela é bem regrada, funcionem à maneira da linguagem." (MC, p. 216, grifos meus).

\footnotetext{
${ }^{44}$ A metáfora espacial do "quadro" é utilizada por Foucault, mas ele insiste que não se trata de uma invenção sua. Numa carta a Michel Amiot, ele esclarece o sentido dessa metáfora para a sua própria análise: "A 'esfera' é uma forma de espacialização que faz parte, explicitamente, dos modos de análise do século XVI: espacialização cosmológica. O 'quadro' é um modo de representação analítica [...], mas que colocou problemas técnicos, muito explícitos, aos classificadores do século XVIII; a importância do 'quadro' em toda a idade clássica, eu não a inventei. Eu tentei dar conta dessa esfera e desse quadro; ao invés de fazer uma análise temática que me teria 'revelado' que a visão de mundo era, no século XVI, esférica, no XVIII, plana, eu tentei mostrar como essas espacializações estavam implicadas por modos de discursividade: a semelhança implica a esfera, as diferenças, o quadro. A transformação não se fez da esfera para o plano (note que isso não seria uma monstruosidade), mas num outro nível. [...] Não se pode então me dizer que eu transformei a esfera em plano (eu mostrei como esta transformação da espacialidade epistemológica tornou-se necessária). [...] Coloca-se então, em geral, o problema muito grave das relações entre espaço e saber." - Michel Foucault. "Lettre de Michel Foucault du 8 mars 1967 en réponse à Michel Amiot". In: Les mots et les choses de Michel Foucault - regards critique 1966 1968. Caen: Presses universitaires de Caen, 2009, pp. 138, 140.
} 


\section{A unidade do modo de ser da linguagem clássica}

Dissolvida no funcionamento da representação, reduzida a um "instrumento" do conhecimento, a linguagem não é propriamente um objeto para o saber clássico. Aí, com efeito, ela adquire um estatuto ambíguo: ao ser encarregada de representar a representação e ao desempenhar um papel fundamental no conhecimento, pode-se dizer que ela é "soberana"; mas, ao mesmo tempo, quando ela perde a densidade de uma coisa intrigante em meio às outras coisas e se retira do mundo, ela se transforma em algo "invisível ou quase" (MC, p. 93); ela se torna "tão transparente à representação que seu ser cessa de suscitar um problema" (MC, p. 93).

Entretanto, dizer que a linguagem não é propriamente um objeto pode soar como uma contradição, quando vemos Foucault falar, por exemplo, de uma "reflexão sobre a linguagem" (MC, p. 98, grifo meu) para se referir à gramática geral. Poderíamos então questionar se, de fato, o surgimento dessa disciplina por volta da metade do século XVII não mostraria que a linguagem seria algo mais do que somente um "instrumento" do conhecimento. Isto indicaria uma cisão que colocaria a linguagem, por um lado, ligada ao ato de conhecer e, por outro, como aquilo que está para ser conhecido em sua espessura própria. No entanto, esta cisão logo se mostra como uma mera aparência quando a arqueologia descreve o campo epistemológico da gramática geral. Tal descrição, na verdade, só vem reforçar a ambiguidade do estatuto da linguagem. Ela mostra que a gramática geral é, sem dúvida, uma teoria da linguagem clássica, mas, através da sua transparência e, do seu caráter, digamos, quase-objetivo, aí reencontramos uma teoria da representação estritamente articulada com uma teoria dos signos e a posição fundamental que ela ocupa no saber clássico. Noutras palavras, no fundo, a gramática geral não é outra coisa que uma teoria da representação enquanto esta é representada pelas palavras; em suma, ela é uma teoria do funcionamento representativo do Discurso. Segundo Foucault, a "generalidade" da gramática geral:

não consiste em encontrar as leis propriamente gramaticais que seriam comuns a todos os domínios linguísticos, e fariam aparecer, em uma unidade ideal e coercitiva, a estrutura de toda língua possível; se ela é geral, é na medida em que ela tem o propósito de fazer aparecer, sob as regras da gramática, mas no nível do fundamento delas, a função representativa do discurso, - que esta seja a função vertical que designa um representado ou aquela, horizontal, que o liga do mesmo modo que o pensamento. Uma vez que ela faz aparecer a linguagem como uma representação que articula uma outra, ela é de pleno direito 'geral': isto do que ela trata é da duplicação interior da representação. (MC, p. 106) 
Como veremos, a partir do momento em que essa identidade entre a teoria da representação e a reflexão sobre a linguagem começar a ser questionada, o saber clássico encontrará o seu limiar. Contudo, enquanto isso não acontece, essa identidade é assegurada pela gramática geral. E, na medida em que, segundo Foucault, "a ordem na natureza e a ordem nas riquezas têm, para a experiência clássica, o mesmo modo de ser que a ordem das representações tal como ela é manifestada pelas palavras" (MC, p. 216), a gramática geral, na disposição arqueológica desse saber, apresenta um certo desnível epistemológico em relação às outras disciplinas empíricas tratadas pela arqueologia do saber clássico. Tal desnível aparece enquanto teoria do funcionamento representativo do Discurso, isto é, uma teoria acerca de como a linguagem pode representar as representações segundo uma certa ordem. A sua configuração epistemológica fornece, ao nível arqueológico, como que um modelo conforme ao qual se organizaram sistematicamente os conhecimentos das outras empiricidades:

\begin{abstract}
A possibilidade de conhecer as coisas e sua ordem passa, na experiência clássica, pela soberania das palavras: estas não são exatamente nem marcas a decifrar (como na época da Renascença), nem instrumentos mais ou menos fiéis e controláveis (como na época do positivismo); elas formam, antes, a rede incolor a partir da qual os seres se manifestam e as representações se ordenam. Daí, sem dúvida, o fato de que a reflexão clássica sobre a linguagem, fazendo parte de uma disposição geral em que ela entra ao mesmo título que a análise das riquezas e a história natural, exerce em relação a elas um papel diretivo [recteur]. (MC, p. 322, grifos meus)
\end{abstract}

Em vista disso, podemos destacar a unidade da linguagem clássica, isto é, o fato de que tanto no domínio da gramática geral, quanto nos outros domínios do saber, ela possui o mesmo modo de ser. A gramática geral determina a especificidade dos signos verbais em relação aos outros signos, quando se trata de representar a representação. Noutras palavras, ela revela as condições sob as quais a linguagem pode funcionar como Discurso. Foucault mostra que essa especificidade dos signos verbais é definida segundo quatro "teorias" que, ao mesmo tempo, descrevem as coordenadas da configuração epistemológica da gramática geral. Tais "teorias" são aquelas da atribuição (ou da proposição e do verbo), da articulação, da designação e da derivação. A seguinte passagem sintetiza essas coordenadas:

Uma vez que o discurso liga suas partes como a representação seus elementos, a gramática geral deverá estudar o funcionamento representativo das palavras umas em relação às outras: o que supõe, primeiro, uma análise da ligação que vincula as palavras conjuntamente (teoria da proposição e singularmente do verbo), depois uma análise dos diversos tipos de palavras e da maneira que elas recortam a representação e se distinguem entre si (teoria da articulação). Mas, já que o discurso não é simplesmente um conjunto representativo, mas uma representação reduplicada que designa outra - 
aquela mesma que ela representa - a gramática geral deve estudar a maneira pela qual as palavras designam o que elas dizem, primeiramente no seu valor primitivo (teoria da origem e da raiz), depois na sua capacidade permanente de deslizamento, de extensão, de reorganização (teoria do espaço retórico e da derivação). (MC, pp. 106-107)

Não é o caso aqui de analisar cada uma dessas teorias. Antes, importa-nos apontar que, visando a linguagem no interior do campo epistemológico da gramática geral, que é formado por esses quatro segmentos teóricos, o arqueólogo mostra que, através da articulação coerente que há entre eles (compondo o que ele chama de “quadrilátero da linguagem” (MC, p. 131)), é possível apreender a "unidade sólida e comprimida da linguagem" (MC, p. 135) no saber clássico. Contudo, não se poderia afirmar essa unidade da linguagem no saber clássico se fosse possível apreendê-la tão somente a partir do interior do domínio da gramática geral. Foucault mostra então, de outro ponto de vista, que no exterior desse domínio a linguagem mantém a mesma natureza de Discurso: na medida em que forma um sistema de signos privilegiado para se estabelecer as ordens empíricas (inclusive a das palavras ${ }^{45}$ ), ela, enquanto Discurso, é o elemento comum no qual é possível descrever a correspondência entre os segmentos teóricos que formam os domínios da história natural e da análise das riquezas com aqueles que formam a gramática geral. Assim, vemos que o "papel diretivo" desta se deve a um certo caráter reflexivo que ela possui no saber clássico, isto é, por seus quatro segmentos teóricos determinarem as condições pelas quais a linguagem pode funcionar como Discurso, eles determinam, ao mesmo tempo, a configuração epistemológica geral das outras empiricidades clássicas. Por isso, o arqueólogo afirma que:

\begin{abstract}
As quatro funções que definem em suas propriedades singulares o signo verbal e o distinguem de todos os outros signos que a representação pode dar a si mesma, reencontram-se então na assinalação teórica da história natural e na utilização prática dos signos monetários. A ordem das riquezas, a ordem dos seres naturais se instauram e se descobrem na medida em que se estabelecem entre os objetos de necessidade, entre os indivíduos visíveis, sistemas de signos que permitem a designação das representações umas pelas outras, a derivação das representações significantes em relação às significadas, a articulação do que é representado, a atribuição de algumas representações a algumas outras. Nesse sentido, pode-se dizer que, para o pensamento clássico, os sistemas da história natural e as teorias da moeda e do comércio têm as mesmas condições de possibilidade que a linguagem mesma. (MC, p. 216)
\end{abstract}

\footnotetext{
45 “A gramática geral não visa definir as leis de todas as línguas, mas tratar, uma a uma, cada língua particular como um modo de articulação do pensamento sobre si mesmo. Em toda língua, tomada isoladamente, a representação se dá 'caracteres'. A gramática geral definirá o sistema de identidades e de diferenças que supõem e que utilizam esses caracteres espontâneos. Ela estabelecerá a taxinomia de cada língua. Ou seja, o que funda em cada uma a possibilidade de tomar um discurso.” (MC, p. 106)
} 
Podemos compreender, então, em que sentido Foucault dizia, como vimos no início deste capítulo, que o Discurso, no saber clássico, possui uma "força de organização sobre o mundo empírico". A arqueologia desse saber analisa "ao mesmo tempo e num só movimento, a gramática geral, a história natural e a economia, reportando-os a uma teoria geral dos signos e da representação" (MC, p. 90). Desta maneira, Foucault mostra como é possível descrever "isomorfismos entre os conhecimentos" dessas disciplinas que podem parecer isoladas umas das outras, de modo que, juntas, elas formam um "sistema de simultaneidade". No entanto, o que permite essa organização sistemática é a unidade da linguagem clássica, isto é, na medida em que as quatro "funções", que a definem como Discurso, dão a forma do "espaço fundamental do quadro". Neste, o ordenamento sucessivo dos elementos das representações empíricas é feito através de uma taxinomia, que os analisa e os articula gradualmente segundo suas identidades e diferenças. 


\section{Capítulo 2 \\ A coexistência do homem com a linguagem no saber moderno}

Como dissemos no início deste trabalho, pensamos que o diagnóstico do presente de As palavras e as coisas consiste em mostrar o modo de coexistência, no saber moderno, da figura epistemológica do homem com um questionamento sobre o "ser da linguagem". No que se segue, procuraremos então esclarecer o que esta formulação, nada óbvia, quer dizer. Para isso, iremos acompanhar como Foucault descreve a constituição de cada um dos termos desse diagnóstico e como eles passaram a coexistir, de tal maneira que esta coexistência se apresenta, de um ponto de vista arqueológico, como um ponto de tensão no cerne do saber moderno. Mas, dizíamos, também, que as análises do saber clássico que Foucault realiza não seriam sem interesse para o que ele diz sobre a sua época, e que o ponto pelo qual podemos apreender tal interesse seria a descrição do modo de ser da linguagem clássica - especialmente de duas características maiores que ela possuía neste saber. A primeira era que, sendo estritamente ligada ao conhecimento e dissolvida em um "puro funcionamento" (MC, p. 350), definindo-se assim como Discurso, a linguagem clássica consistia num sistema de signos privilegiado que tornava possível que a representação fundasse no seu próprio espaço o jogo de suas análises e de suas sínteses. A segunda era a sua unidade, que se mostrava pela articulação coerente das quatro "teorias" que configuravam o campo epistemológico da gramática geral e determinavam a peculiaridade dos signos verbais em relação aos signos em geral, quando se tratava de representar a representação. Ao mesmo tempo, a gramática geral possuía, também, um "papel diretivo" em relação à história natural e a análise das riquezas, uma vez que aquelas "teorias" forneciam como que um modelo conforme o qual se configuraram o campo epistemológico dessas disciplinas e, nesse sentido, o Discurso possuía uma "força de organização sobre o mundo empírico", constituindo o espaço das representações empíricas como o "espaço fundamental do quadro".

Tendo em vista estas características, podemos determinar melhor agora de que modo as análises de Foucault sobre a idade clássica entram na elaboração do diagnóstico do presente de As palavras e as coisas. Procuremos, então, compreender esse diagnóstico a partir da relação destes três termos: o homem, a linguagem (segundo o modo de ser que ela irá assumir na modernidade) e o Discurso (a linguagem clássica). 
Como obseva Michel de Certeau, "cada região histórica da epistémê é o lugar de uma reestruturação comandada (mas não mais organizadas) pelas estruturas elaboradas na época anterior" ${ }^{46}$. Embora Foucault vá mostrar uma série de transformações que instauraram uma descontinuidade entre a ordem do saber clássico e a ordem do saber moderno, é somente em relação à primeira que a arqueologia pode descrever a organização e a sistematicidade próprias da segunda. Assim, quando apontamos para a necessidade de tal relação entre ordens distintas do saber, não se trata, de modo algum, de procurar contornar a descontinuidade que Foucault descreve entre elas. Trata-se, antes, de afirmar que é a partir das suas diferenças que pode aparecer o limiar que as separa e, assim, permitindo-nos traçar os "contornos" das novas figuras que despontam numa nova ordem do saber. Noutras palavras, se a descrição da linguagem clássica, do Discurso, entra na elaboração do diagnóstico do presente de As palavras e as coisas, é porque será a partir da transformação do seu modo de ser, por volta do início do século XIX, que Foucault descreverá o limiar a partir do qual puderam surgir a figura epistemológica do homem e o modo de ser moderno da linguagem.

Como vimos no primeiro capítulo, o nível arqueológico do saber clássico coincidia com o sistema dos signos e com a natureza que eles assumiram a partir da metade do século XVII ${ }^{47}$. E, uma vez que a linguagem se definia em correlação com a teoria clássica dos signos em geral, encontrando-se, pelas suas características próprias, numa "situação fundamental" em relação aos conhecimentos das ordens empíricas, a descontinuidade entre o saber clássico e o saber moderno se consuma quando ela deixa de desempenhar o seu papel analítico e organizador no espaço da representação; em suma, quando o Discurso desaparece. Como diz Foucault:

todo o sistema de crivos que analisava a sequência das representações (tênue série temporal desenrolando-se no espírito dos homens) para fazê-la oscilar, para detê-la, desdobrá-la e reparti-la num quadro permanente; todas essas manobras [chicanes] constituídas pelas palavras e pelo discurso, pelos caracteres e pela classificação, pelas equivalências e pela troca são agora abolidas a ponto de ser difícil reencontrar a maneira como esse conjunto pôde funcionar. A última 'peça' que saltou - e cuja desaparição afastou para sempre de nós o pensamento clássico - é o primeiro desses crivos: o discurso que assegurava o desdobramento inicial, espontâneo, ingênuo da

\footnotetext{
${ }^{46}$ Michel de Certeau. Histoire et psychanalyse - entre science et fiction. Paris: Éditions Gallimard, 1987, pp. 166,167 , grifos meus.

47 "O que é um signo na idade clássica? Pois o que mudou na primeira metade do século XVII, e por muito tempo - talvez até nós -, foi o regime inteiro dos signos, as condições sob as quais eles exercem sua estranha função; foi o que, dentre tantas outras coisas que se sabe ou que se vê, erige-os subitamente como signos; foi seu próprio ser. No limiar da idade clássica, o signo cessa de ser uma figura do mundo; e ele cessa de ser ligado ao que ele marca por ligações sólidas e secretas da semelhança ou da afinidade." (MC, p. 72, grifos meus)
} 
representação em quadro. No dia em que ele cessou de existir e de funcionar no interior da representação como sua ordenação primeira, o pensamento clássico cessou, ao mesmo tempo, de nos ser diretamente acessível.

O limiar do classicismo à modernidade (mas pouco importa as palavras mesmas - digamos, da nossa pré-história ao que ainda nos é contemporâneo) foi definitivamente atravessado quando as palavras cessaram de se entrecruzar com as representações e de esquadrinhar espontaneamente o conhecimento das coisas. (MC, p. 315, grifos meus)

O Discurso, portanto, entra na elaboração do diagnóstico do presente de $A s$ palavras e as coisas, paradoxalmente, na medida em que ele desaparece por volta do início do século XIX. Quer dizer, por um lado, será em relação ao desaparecimento da unidade da linguagem clássica que Foucault irá ressaltar o estatuto fragmentário e disperso que ela assume no saber moderno. Estatuto em relação ao qual este saber irá se “inquietar" e fará proliferar uma série de questões acerca do "ser da linguagem", que, como vimos, no saber clássico, reduzido ao "puro funcionamento" representativo do Discurso, não podia suscitar problemas. A partir do início do século XIX, diz Foucault, “com a reaparição da linguagem numa expansão múltipla, a ordem do pensamento clássico pode doravante se apagar" (MC, p. 314, grifos meus). Trataremos, então, da importância deste acontecimento para o que Foucault diz sobre a sua época na segunda seção deste capítulo, pois, antes, para que possamos compreender como a figura epistemológica do homem passou a coexistir com tal questionamento sobre o "ser da linguagem" e como essa coexistência se apresenta no modo de uma tensão no saber moderno, cumpre tratar da relação do desaparecimento do Discurso com o surgimento desta figura: como entender as afirmações de Foucault segundo as quais "o homem existiu lá onde o discurso se calou" (DE I, 34, p. 529), ou que o homem é "esta figura que outrora tomara justamente o lugar do Discurso clássico" (MC, p. 394)?

Por um lado, como veremos, o aparecimento de um questionamento sobre o "ser da linguagem" se tornou possível pelo desaparecimento da unidade da linguagem clássica e pela sua dispersão, quando ela deixou de ser transparente à representação. Por outro lado, uma vez separada da representação, ela não mais poderá assegurar, de uma maneira privilegiada em relação aos outros signos, a fundamentação de suas análises e de suas sínteses no seu próprio espaço. No saber clássico, “os signos são coextensivos à representação, isto é, a todo pensamento: desde que uma representação é ligada a uma outra e representa em si mesma esta ligação, há signo” (MC, p. 79). Assim, se é característico da representação representar a sua representatividade e ligar-se a uma outra, o saber clássico não podia, dada a natureza do signo (inclusos aí os signos verbais), tomar distância da representação para questionar o seu poder representativo 
fora do seu próprio espaço. Logo, o desaparecimento do Discurso abre não só a possibilidade, mas, também, coloca a necessidade de que o problema da fundamentação filosófica do conhecimento apareça na forma pela qual ele foi tratado no saber moderno, isto é, por uma "análise do modo de ser do homem, tal como ela se desenvolveu desde o século XIX” (MC, p. 348). Esta análise, continua Foucault,

\begin{abstract}
não se aloja no interior de uma teoria da representação; sua tarefa é, muito pelo contrário, mostrar como é possível que as coisas em geral sejam dadas à representação, em que condições, sobre qual solo, em quais limites elas podem aparecer numa positividade mais profunda que os modos diversos da percepção. [...] A analítica do homem não retoma, tal como ela foi constituída alhures e que a tradição the legou, a análise do discurso. A presença ou a ausência de uma teoria da representação, mais exatamente, o caráter primeiro ou a posição derivada dessa teoria modifica inteiramente o equilíbrio do sistema. (MC, p. 348)
\end{abstract}

Em vista disso, podemos avançar, desde já, uma primeira resposta à questão que levantamos: se o lugar do homem na ordem do saber moderno corresponde ao lugar do Discurso na ordem do saber clássico, é porque, de um ponto de vista arqueológico, quando a "teoria geral da representação desaparecia [...] impunha-se, em contrapartida, a necessidade de interrogar o ser do homem como o fundamento de todas as positividades" (MC, p. 356, grifo meu) que surgiram a partir do século XIX, isto é, da economia política, da biologia e da filologia.

Entretanto, como veremos na primeira seção deste capítulo, esta "analítica do homem" consiste numa espécie de torção que se apresenta no saber moderno. Pois, se o desaparecimento do Discurso e, consequentemente, disto que Foucault chama de uma "teoria geral da representação", para se referir a todo o domínio dos conhecimentos empíricos em relação ao qual o Discurso se encontrava numa "situação fundamental"48; se isto impõe a necessidade de se colocar o problema da fundamentação filosófica do conhecimento nos termos de uma análise do modo de ser do homem; a arqueologia mostrará que o surgimento da sua figura epistemológica é tributária dos próprios conhecimentos empíricos daquelas positividades que se pretende fundar com tal análise. Ou seja, a figura epistemológica do homem só pôde surgir no saber moderno "quando,

\footnotetext{
${ }^{48}$ No saber clássico, diz Foucault: "a representação comanda o modo de ser da linguagem, dos indivíduos, da natureza e da própria necessidade [besoin]. A análise da representação possui, portanto, valor determinante para todos os domínios empíricos. Todo o sistema clássico da ordem, toda essa grande taxinomia que permite conhecer as coisas pelo sistema de suas identidades, desdobra-se no espaço que a representação abre no interior de si quando ela se representa a si mesma. [...] O fim do pensamento clássico - e desta epistémê que tornou possíveis a gramática geral, a história natural e a ciência das riquezas - coincidirá com o recuo da representação, ou, antes, com a liberação, relativamente à representação, da linguagem, do vivente e da necessidade. [...] A idade clássica acaba de terminar e com ela o reino do discurso representativo, a dinastia de uma representação significando a si mesma e enunciando, na sequência de suas palavras, a ordem adormecida das coisas." - (MC, pp. 221-222)
} 
abandonando o espaço da representação, os seres vivos alojaram-se na profundeza específica da vida, as riquezas no ímpeto [poussée] progressivo das formas de produção, as palavras no devir das linguagens" ( $\mathrm{MC}, \mathrm{p}$. 356). Isto porque foi através dos conteúdos empíricos da biologia, da economia política e da filologia que se pôde entrever as determinações das leis da vida, da produção e da historicidade da linguagem sobre a existência concreta do homem, de modo que foi no domínio da finitude humana que o problema suscitado pelo desaparecimento do Discurso apareceu:

\begin{abstract}
A antropologia como analítica do homem teve, certamente, um papel constitutivo no pensamento moderno, uma vez que em grande parte nós ainda não nos desprendemos dela. Ela se tornou necessária a partir do momento em que a representação perdeu o poder de determinar por ela mesma e em um movimento único o jogo das suas sínteses e das suas análises. Era preciso que as sínteses empíricas fossem asseguradas noutro lugar que na soberania do "Eu penso". Elas deviam ser requisitadas lá onde precisamente esta soberania encontra seu limite, ou seja na finitude do homem - finitude que é tanto aquela da consciência quanto do indivíduo vivente, falante, trabalhador. (MC, pp. 351-352)
\end{abstract}

Assim, pode-se dizer que a fundamentação filosófica do conhecimento constitui, no geral, o problema com o qual lida o tipo de reflexão que se desenvolve no campo epistemológico que Foucault chama de antropologia; um tipo de reflexão ao qual Foucault se refere como "analítica do homem", mas, também, como "analítica da finitude" (MC, p. 326). Voltando-se então para o interior desse campo, ele irá descrever a sua formação arqueológica, isto é, cada um dos "segmentos teóricos" (MC, p. 346) que o constituem. Esses “segmentos” formam, segundo Foucault, um “"quadrilátero' antropológico" (MC, p. 353):

a ligação das positividades à finitude, a reduplicação do empírico no transcendental, a relação perpétua do cogito ao impensado, a retirada e o retorno da origem definem para nós o modo de ser do homem. É sobre a análise desse modo de ser, e não mais sobre aquela da representação, que desde o século XIX a reflexão procura fundar filosoficamente a possibilidade do saber. (MC, p. 346)

Uma leitura apressada logo diria que se, negativamente, o desaparecimento do Discurso impõe a necessidade de se interrogar sobre a fundamentação filosófica do saber através de uma "analítica do homem", positivamente, seria na esteira da filosofia crítica de Kant que este problema se coloca. Afinal, se, no início do século XIX, o desaparecimento do Discurso consumou a descontinuidade entre o saber clássico e o saber moderno, cronologicamente, Kant foi quem deu o primeiro passo para além dos "limites da representação", quando colocou a questão das condições de possibilidade das representações em geral. Coexistindo no final do século XVIII, a Ideologia (“a 
última das filosofias clássicas" (MC, p. 255)) e a filosofia crítica partilham, segundo Foucault, uma mesma questão: "por muito diferente que elas sejam pela sua forma, seu estilo e seu propósito, a questão kantiana e aquela dos Ideólogos tem um mesmo ponto de aplicação: a relação das representações entre si” (MC, p. 254). Foucault, no entanto, mostra que cada uma irá responder a essa questão a seu modo. A Ideologia, percorrendo o espaço das representações, define as suas relações no interior deste mesmo espaço e as funda em geral na representação simples da sensação (cf. MC, p. 254). A crítica kantiana, por sua vez, interroga a relação das representações:

na direção do que a torna possível na sua generalidade. Ao invés de fundar a ligação entre as representações por um tipo de escavação interna que a esvazia pouco a pouco até a pura impressão, ele a estabelece sobre as condições que definem sua forma universalmente válida. Dirigindo assim a questão, Kant contorna a representação e o que é dado nela, para se dirigir àquilo mesmo a partir do que toda representação, seja ela qual for, pode ser dada. [...] Toda ligação, se ela deve ser universal, deve se fundar além de toda experiência, no a priori que a torna possível. Não que se trate de um outro mundo, mas das condições sob as quais pode existir toda representação do mundo em geral. [...] Em face da Ideologia, a crítica kantiana marca [...] o limiar da nossa modernidade. Ela sanciona assim pela primeira vez este acontecimento da cultura europeia que é contemporâneo do fim do século XVIII: o recuo do saber e do pensamento para fora do espaço da representação $^{49}$. (MC, pp. 254-255, grifos meus)

Assim, na perspectiva de uma história da filosofia que procuraria mostrar as "influências" e as "paternidades" das teorias, é certo que a antropologia "descenderia" de alguma maneira da reflexão transcendental tal como ela foi realizada por Kant. No entanto, para uma arqueologia do saber moderno, não se trata de descrever esses tipos de relações. Importa, antes, mostrar que o tipo de reflexão que se tornou possível com o surgimento do homem foi suscitado pelos conhecimentos produzidos no domínio empírico do saber moderno, especialmente, aqueles da biologia, da economia política e da filologia. Nesse sentido, Foucault aponta um "quádruplo deslocamento com relação à questão kantiana":

\footnotetext{
${ }^{49}$ Analogamente a coexistência de Bacon e Descartes na descrição que Foucault faz da descontinuidade que abre o saber clássico, a Ideologia e a filosofia crítica coexistem no fim do século XVIII. Assim como a crítica de Bacon não era capaz de instaurar uma descontinuidade com o saber da renascença, sendo, antes, como diz Foucault, "o pensamento do século XVI inquietando-se diante de si mesmo e começando a se desprender das suas figuras mais familiares" (MC, p. 66), a Ideologia é apresentada nesta mesma posição, isto é, naquela em que mostra o pensamento clássico prestes a se transformar em seu nível arqueológico. Foucault já aponta para esta transformação quando, ainda no começo das suas análises do saber clássico, avança a ideia da perda de transparência entre a ideia e o signo que, como vimos, marcava a disposição fundamental desse saber: "no dia em que a Ideologia, no fim do século XVIII, interrogar-se sobre o primado que é preciso dar para a ideia ou para o signo, no dia em que Desttut acusar Gerando de ter feito uma teoria dos signos antes de ter de ter definido a ideia, é que seu imediato pertencimento começará a se turvar.” (MC, p. 79)
} 
a reflexão transcendental, na sua forma moderna, não encontra o ponto de sua necessidade, como em Kant, na existência de uma ciência da natureza (à qual se opõem o combate perpétuo e a incerteza das filosofias), mas na existência muda, pronta no entanto para falar e como que toda atravessada secretamente por um discurso virtual, por esse não-conhecido a partir do qual o homem é sem cessar chamado ao conhecimento de si. A questão não é mais: como é possível que a experiência da natureza dê lugar a julgamentos necessários? Mas: como é possível que o homem pense o que ele não pensa, habite o que lhe escapa ao modo de uma ocupação muda, anime, por uma espécie de movimento petrificado, esta figura de si mesmo que se apresenta a ele sob a forma de uma exterioridade teimosa [têtue]? Como o homem pode ser essa vida cuja rede, cujas pulsações, cuja força enterrada transborda indefinidamente a experiência dela que lhe é imediatamente dada? Como ele pode ser esse trabalho cujas exigências e leis impõem-se a ele como um rigor estrangeiro? Como ele pode ser o sujeito de uma linguagem que desde milênios se formou sem ele, cujo sistema lhe escapa, cujo sentido dorme um sono quase invencível nas palavras que ele faz, um instante, cintilar pelo seu discurso e no interior do qual ele é, de saída, constrangido a alojar sua fala e seu pensamento, como se eles não fizessem nada mais do que animar algum tempo um segmento sobre essa trama de possibilidades inumeráveis? Quádruplo deslocamento com relação à questão kantiana, já que se trata não mais da verdade, mas do ser; não mais da natureza, mas do homem; não mais da possibilidade de um conhecimento, mas daquela de um desconhecimento primeiro; não mais do caráter não fundado das teorias filosóficas em face da ciência, mas da retomada, numa consciência filosófica clara de todo esse domínio de experiências não fundadas em que o homem não se reconhece." (MC, p. 334)

Todavia, como apontamos no início deste trabalho, o diagnóstico do presente de As palavras e as coisas é, em larga medida, motivado por uma crítica a este tipo de reflexão que se tornou possível com o surgimento do homem no saber moderno. De um modo geral, esta crítica consiste em mostrar que esta é "uma reflexão de nível misto" (MC, p. 352), na qual o fundamento sempre aparece como sendo da mesma ordem que o fundado; uma reflexão para a qual "todo conhecimento empírico, desde que ele concerne ao homem, vale como campo filosófico possível, em que se deve descobrir o fundamento do conhecimento, a definição dos seus limites e finalmente a verdade de toda verdade" (MC, p. 352). Nesse sentido, Foucault afirma que esta reflexão opera uma "confusão do empírico e do transcendental, cuja partilha, porém, Kant mostrara" (MC, p. 352). Ora, diante de uma afirmação como esta, poderíamos pensar que, se a reflexão antropológica é criticável, é porque, em última instância, ela não teria sido capaz de fundamentar o conhecimento num sujeito transcendental, o que só seria possível se ela tivesse obedecido aos critérios daquela partilha. Mas seria mesmo isto o que a sua crítica nos mostra? Seria mesmo por esta razão que Foucault afirma que, através de um processo de autoesgotamento, esse tipo de reflexão teria adormecido num "sono antropológico" (MC, p. 351)? 
Com efeito, não nos parece que este seja o caso. Como veremos na primeira seção deste capítulo, não se trata, para Foucault, de criticar um tipo de reflexão em nome de uma outra que fosse "mais verdadeira". Essa crítica se concentra, em larga medida, numa perspectiva que se pode considerar como interna ao campo da antropologia no saber moderno, isto é, aquela que mostra que a "analítica da finitude" é fadada ao autoesgotamento através da descrição da própria configuração arqueológica que a tornou possível. No entanto, como veremos na segunda seção, a partir de uma perspectiva que se pode considerar como externa a esse campo, que o visa na disposição geral do saber moderno, Foucault acrescenta um outro elemento decisivo para essa crítica. Este consiste em mostrar "qual ameaça faz pesar sobre o ser do homem [...] a reaparição contemporânea da linguagem no enigma da sua unidade e de seu ser" (MC, p. 349, grifos meus). Esse elemento, então, permite ver também como a crítica à antropologia está amparada nessa espécie de ontologia histórica da linguagem que Foucault realiza em As palavras e as coisas. Além disso, será através dele que poderemos apreender o seu diagnóstico do presente. Ambas perspectivas se articulam de tal maneira que através delas podemos ver que a figura epistemológica do homem é descrita como uma figura problemática desde o seu surgimento.

\section{A projeção do homem no saber moderno como "figura da finitude": a constituição do campo da antropologia}

Simultaneamente à investida kantiana para além dos limites da representação, constituem-se, na virada do século XVIII, novas positividades cujo conhecimento não é mais possível apenas pela análise interna da representação ${ }^{50}$. Ou seja, esse "desnível do ser em relação à representação, de que o kantismo é a primeira constatação filosófica" (MC, p. 258, grifo meu), consiste num acontecimento que atinge o nível arqueológico do saber ${ }^{51}$, cuja amplitude abarca todo o domínio dos conhecimentos empíricos no final do século XVIII e que se mostra através do movimento pelo qual as novas

\footnotetext{
${ }^{50}$ Como bem notou Georges Canguilhem, "um dos pontos difíceis da demonstração de Foucault é o de tornar claro a conivência não premeditada do kantismo e dos trabalhos de Cuvier, Ricardo e Bopp na manifestação da epistémê do século XIX." (Georges Canguilhem. "Mort de l'homme ou épuisement du Cogito?". In: Les mots et les choses de Michel Foucault - regards critiques 1966-1968. Caen: Presses universitaires de Caen, 2009, p. 269).

${ }^{51}$ Para mostrar que houve uma reconfiguração completa do campo empírico na modernidade, a arqueologia visa num nível específico as transformações que o atingem. Como diz Foucault: "o que mudou na virada do século [XVIII], e sofreu uma alteração irreparável, é o saber mesmo como modo de ser prévio e indiviso entre o sujeito que conhece e o objeto de conhecimento.”- (MC, p. 264)
} 
empiricidades, que surgem nesta época, também ultrapassam os limites da representação. Foucault resume este movimento da seguinte maneira:

em todos os casos, a relação da representação consigo mesma e as relações de ordem que ela permite determinar fora de toda medida quantitativa passam agora por condições exteriores à própria representação em sua atualidade. Para ligar a representação de um sentido com a de uma palavra, é preciso se referir e recorrer às leis puramente gramaticais de uma linguagem que, fora de todo poder de representar as representações, está submetida ao sistema rigoroso de suas modificações fonéticas e de suas subordinações sintéticas; na idade clássica, as línguas tinham uma gramática porque elas tinham poder de representar; agora elas representam a partir dessa gramática que é para elas como que um reverso histórico, um volume interior e necessário cujos valores representativos não são mais que a face externa, cintilante e visível. Para ligar num caráter definido uma estrutura parcial e a visibilidade de conjunto de um ser vivo, é preciso agora se referir às leis puramente biológicas que, fora de todas as marcas sinaléticas e como que em recuo em relação a elas, organizam as relações entre funções e órgãos; os seres vivos não definem mais suas semelhanças, suas afinidades e suas famílias a partir da sua descritibilidade desdobrada; eles possuem caracteres que a linguagem pode percorrer e definir porque eles possuem uma estrutura que é como o reverso sombrio, volumoso e interior da sua visibilidade: é na superfície clara e discursiva desta massa secreta, mas soberana, que os caracteres emergem, espécie de depósito exterior na periferia de organismos agora enrolados sobre si mesmos. Enfim, quando se trata de ligar a representação de um objeto de necessidade a todos aqueles que podem figurar em face dele no ato de troca, é preciso recorrer à forma e a quantidade de um trabalho que determina o seu valor; o que hierarquiza as coisas em seus movimentos contínuos do mercado não são os outros objetos nem as outras necessidades; é a atividade que as produziu e que, silenciosamente, depositou-se nelas; são as jornadas e as horas necessárias para fabricá-las, para extraí-las, ou para transportá-las que constituem seu peso próprio, sua solidez mercante, sua lei interior e, assim, o que se pode chamar seu preço real; a partir deste núcleo essencial, as trocas poderão se realizar e os preços de mercado, depois de terem oscilado, encontrarão seu ponto fixo. (MC, pp. 250-251)

Deste modo, a vida surge para a biologia como a condição de possibilidade dos seres vivos, o trabalho surge para a economia política como a condição de possibilidade da troca e da produção e a linguagem, com toda a sua espessura histórica, surge para a filologia como a condição de possibilidade do discurso. O que pode ser representado nos conhecimentos de cada uma dessas ciências não mais esgota os objetos que elas buscam conhecer, já que eles estão submetidos a leis e historicidades que extrapolam aquilo que deles é dado na representação. A vida, o trabalho e a historicidade da linguagem são, portanto, novas positividades que o pensamento clássico desconhecia; mas são, ao mesmo tempo, e sobretudo, aquilo em que as coisas representadas (os seres vivos, o valor dos objetos produzidos, o sentido das palavras) encontram a sua legislação própria. A taxinomia, como modo de conhecimento que as ordenava num "quadro" de identidades e diferenças, não se aplica mais a elas, ou melhor, no saber moderno ela não é mais que um "efeito". Nesse sentido, a representação deixa de 
coincidir com o nível do próprio saber, como na idade clássica, e, assumindo uma posição superficial, "ela se modifica no nível mais profundo de seu regime arqueológico" (MC, p. 246), à medida que o saber se aprofunda. Foucault descreve essa modificação numa passagem que extrai do conjunto dos conhecimentos empíricos dados o novo estatuto que a representação assume no saber; nesses conhecimentos, ou conteúdos empíricos do saber,

a representação que se faz das coisas não tem mais que desdobrar, num
espaço soberano, o quadro de sua ordenação; ela é, do lado desse indivíduo
empírico que é o homem, o fenômeno - menos ainda talvez, a aparência - de
uma ordem que pertence agora às coisas mesmas e à sua lei interior. (MC, p.
324, grifos meus)

No que diz respeito a essa mudança de estatuto da representação no saber moderno, percebe-se então dois movimentos interligados. Por um lado, ao deixar de coincidir com a disposição fundamental do saber, a representação, em relação às coisas, "não é nada mais, doravante, que um efeito, sua alusão mais ou menos confusa em uma consciência que [a]s apreende e [a]s restitui” (MC', p. 324). Isso envolve, por outro lado, o surgimento de uma cisão entre os seres e o ser humano: "na representação, os seres não manifestam mais sua identidade, mas a relação exterior que eles estabelecem com o ser humano" (MC, p. 324). As novas positividades empíricas que aparecem no início do século XIX mostram que as coisas não concernem diretamente ao homem, quer dizer, submetidas às leis e historicidades próprias do trabalho, da vida e da linguagem, não encontram mais na representação que ele tem delas o único modo pelo qual elas se apresentam no saber: “a representação cessou de valer para os seres vivos, para as necessidades e para as palavras, como seu lugar de origem e sede primitiva da sua verdade" (MC, p. 324).

Esse duplo movimento é de grande importância para a compreensão da maneira pela qual o homem entra em cena no saber moderno e da "modalidade que lhe é própria" (MC, p. 323). Ao mesmo tempo em que a representação perde a sua autonomia, deixando de ser o espaço geral do saber, e se torna apenas uma atividade peculiar “desse indivíduo empírico que é o homem”, este aparece então em meio a todos os outros seres empíricos com o diferencial de ser o único entre eles que é dotado do “poder de se dar representações” (MC, p. 324) desses próprios seres e de si mesmo. No saber clássico, diz Foucault,

os temas modernos de um indivíduo vivente, falante e trabalhador segundo as leis de uma economia, de uma filologia e de uma biologia, mas que, por uma espécie de torção interna e de recobrimento, teria recebido, pelo jogo dessas 
próprias leis, o direito de as conhecer e de as trazer inteiramente à luz, todos esses temas para nós familiares e ligados à existência das 'ciências humanas' são excluídos do pensamento clássico. (MC, p. 321, grifos meus)

Em outras palavras, na perspectiva da descrição arqueológica, o despontar do homem no saber moderno é contemporâneo do recuo dos seres vivos, dos objetos de troca e das palavras com relação à representação; o que significa dizer que, tal como eles, o homem aparece empiricamente submetido às leis da vida, da produção e da linguagem, assim como às historicidades próprias a cada uma dessas positividades: "sua existência concreta encontra neles suas determinações" (MC, p. 324).

Logo se vê que, em meio aos outros seres, o homem não constitui por si mesmo um domínio à parte da objetividade no interior do campo empírico do saber moderno, ele não é um objeto especial ao lado de todos aqueles que são conhecidos segundo as leis da vida, do trabalho e da linguagem. Como afirma Foucault: "nem a biologia, nem a economia, nem a filologia devem ser tomadas pelas primeiras ciências humanas, nem pelas mais fundamentais" (MC, p. 363). É certo que os conteúdos desses saberes não deixam de apontar para o homem, "já que é ele quem fala, já que é visto residindo entre os animais [...], já que, enfim, a relação entre as necessidades e os meios que ele possui para satisfazê-las é tal que ele é necessariamente princípio e meio de toda produção" (MC, p. 324). Trata-se, contudo, segundo Foucault, de uma designação ambígua. Pois, se de fato o homem é "requerido" (MC, p. 324) nos saberes empíricos entre os seres vivos, os objetos de troca e as palavras, "só se pode ter acesso a ele através de suas palavras, de seu organismo, dos objetos que ele fabrica - como se eles primeiramente (e somente eles talvez) detivessem a verdade" (MC, p. 324). Ou seja, o homem, "em sua positividade (ser vivente, trabalhador, falante)" (MC, p. 364), aparece somente através da dispersão dos conteúdos empíricos do saber que lhe são exteriores. Eis portanto o sentido da ambiguidade: apontar para o homem é apontar para o que não tem uma espessura própria em direção àquilo que lhe ultrapassa.

Com isso, Foucault começa a delinear as condições que tornam possível o aparecimento da figura epistemológica do homem no saber moderno. Mas, ao nível das positividades empíricas, a ambiguidade da designação dessa figura é ainda reforçada. Isto porque o homem, "desde que pensa", desde que é esse "indivíduo empírico" com "o poder de se dar representações", só pode se representar a si mesmo como um ser marcado pelo anacronismo, ou seja, como um ser imerso "numa irredutível anterioridade", na medida em que "é já [...] um ser vivo, um instrumento de produção, 
um veículo para palavras que lhe preexistem” (MC', p. 324, grifos meus). E como tal, através desses conteúdos que o determinam, ele aparece "como se [...] não fosse nada mais que um objeto da natureza ou um rosto que deve se apagar na história" (MC', p. 324, grifos meus). Assim, mesmo que ao nível das positividades o homem seja designado de uma forma ambígua, mesmo que aí ele não consista num objeto especial, através dos conteúdos empíricos da biologia, da economia e da filologia é possível depreender a sua finitude:

sabe-se que o homem é finito como se conhece a anatomia do cérebro, os mecanismos dos custos da produção ou o sistema da conjugação indoeuropeia; ou, antes, pela filigrana de todas estas figuras sólidas, positivas e plenas, percebe se a finitude e os limites que elas impõem, entrevê-se como em branco tudo que elas tornam impossível. (MC, pp. 324-325, grifos meus)

Foucault, contudo, não deixa de lembrar que o pensamento clássico não ignorou a ideia da finitude. Mas, do ponto de vista arqueológico, dizer que a finitude humana se anuncia no saber, e pela primeira vez, significa que, com o fim da idade clássica, ela não é mais concebida em relação a uma metafísica do infinito. Aí se concentra toda a diferença entre os modos pelos quais a finitude aparece no saber clássico e no saber moderno. No primeiro, sendo pensada como "inadequação ao infinito" (MC, p. 327), esta relação é dada anteriormente a todo conteúdo empírico do saber, fundando-os ao mesmo tempo em que justifica o conhecimento limitado que deles se podia ter; no segundo, deixando-se entrever através dos conteúdos empíricos do saber, "a experiência que se forma no começo do século XIX aloja a descoberta da finitude não mais no interior do pensamento do infinito, mas no próprio cerne desses conteúdos que são dados, por um saber finito, como as formas concretas da existência finita" (MC, p. 327).

Segundo Foucault, nesses conteúdos exteriores ao homem, a finitude humana ${ }^{52}$ aparece na positividade "de uma maneira imperiosa" (MC, p. 324) e, na perspectiva da arqueologia, não sendo mais pensada como "inadequação ao infinito" (MC, p. 327), é o que torna possível a projeção da figura epistemológica do homem no saber moderno:

fundamentalmente, nossa cultura atravessou o limiar a partir do qual nós
reconhecemos nossa modernidade no dia em que a finitude foi pensada em
uma referência interminável a ela mesma. Se é verdade, ao nível dos
diferentes saberes, que a finitude é sempre designada a partir do homem
concreto e das formas empíricas que se podem atribuir à sua existência, ao
nível arqueológico, que descobre o a priori histórico e geral de cada um dos
saberes, o homem moderno - esse homem determinável em sua existência
corporal, laboriosa e falante - só é possível a título de figura da finitude. A

\footnotetext{
${ }^{52} \mathrm{Ou}$ seja, não se trata da finitude do sujeito transcendental que aparece na Crítica kantiana, finitude que
} não é dada pelos conteúdos da experiência. 
cultura moderna pode pensar o homem porque ela pensa o finito a partir dele próprio. (MC, p. 329, grifos meus)

Mas, se a finitude humana se deixa ver através dos conteúdos dos saberes empíricos, esses saberes tendem a desviá-la dessa referência a si mesma e, nesse sentido, ela se apresenta "sob a forma paradoxal do indefinido" (MC, p. 325). A prova disso é que nos saberes empíricos ainda se vislumbra a possibilidade de sua superação; quer dizer, ainda que seus conteúdos revelem limites que de fato se impõem à existência concreta do homem, esses saberes ainda relacionam a finitude humana com algo que estaria para além dela mesma: como que a uma versão do infinito, que sob a forma do tempo não pode ser pensada senão como um porvir. Ao tentar contornar os limites que seus conteúdos deixam entrever, os saberes empíricos, como nota Sabot, ainda se ligam à "promessa escatológica de uma recuperação total do homem por ele mesmo" ${ }^{\text {"53. }}$

\begin{abstract}
A evolução da espécie não está talvez concluída; as formas da produção e do trabalho não cessam de modificar-se e, talvez um dia, o homem não encontrará mais no seu labor o princípio de sua alienação, nem nas suas necessidades a constante evocação de seus limites; e nada prova, tampouco, que ele não descobrirá sistemas simbólicos suficientemente puros para dissolver a velha opacidade das linguagens históricas. (MC, p. 325)
\end{abstract}

Foucault, no entanto, pretende mostrar como, no saber moderno, a experiência da finitude é incontornável e de que maneira ela se fixa sobre si mesma. Para isso, não basta considerar como ela se apresenta na positividade a partir da maneira como certas teorias procuraram dissimulá-la através de uma escatologia. A análise arqueológica deve então se repartir e relacionar o que pode ser considerado como dois níveis: o nível das positividades empíricas (visado até aqui) e o nível do fundamental ${ }^{54}$. A instauração deste segundo nível e a relação dele ao primeiro é explicitada quando Foucault afirma que os conteúdos dos saberes empíricos, com o que eles "deixam também apontar para os confins do tempo, não se oferecem à tarefa de um conhecimento possível senão ligados inteiramente à finitude" (MC, p. 325). O que significa essa ligação?

Primeiramente, é importante nos precaver de uma leitura apressada e notar que, ao dizer que os conteúdos empíricos só podem ter positividade no saber se ligados à finitude, Foucault não os remete a uma "teoria do sujeito". A essa finitude corresponde uma "experiência do homem" (MC, p. 325)

\footnotetext{
${ }^{53}$ Philippe Sabot. Lire Les mots et les choses de Michel Foucault. Paris: PUF, 2006, p. 127.

${ }^{54}$ Toda a descrição da analítica da finitude se desenvolverá a partir da relação desses dois níveis.

${ }^{55}$ Ao remeter a essa "experiência" e ao apresentar, como veremos, o seu caráter fundamental pelo qual se determina a auto-referência da finitude, Foucault ainda está descrevendo como se constitui o espaço epistemológico sobre o qual uma "teoria do sujeito" virá se desenvolver e ser problematizada pela
} 
à experiência do homem, um corpo é dado que é seu corpo - fragmento de espaço ambíguo, cuja espacialidade própria e irredutível se articula contudo sobre o espaço das coisas; a esta mesma experiência o desejo é dado como apetite primordial, a partir do qual todas as coisas adquirem valor, e valor relativo; a esta mesma experiência, uma linguagem é dada no fio da qual todos os discursos de todos os tempos, todas as sucessões e todas as simultaneidades podem ser dadas. (MC, p. 325)

Assim, se ao nível das positividades empíricas a finitude humana só pode ser depreendida através da dispersão dos conteúdos do saber; se ela aparece então como que do exterior, mostrando o homem como um ser atravessado pelas determinações da natureza e da história ${ }^{56}$; se isso, enfim, dá margem para que nos saberes empíricos ela ainda seja concebida em relação a um porvir; ao dizer que, no saber moderno, tais conteúdos empíricos estão ligados à experiência do corpo, do desejo e da linguagem, Foucault mostra que a finitude humana não pode escapar de uma referência a si mesma. Mas, se o que os conteúdos empíricos do saber deixam ver são as limitações que se impõem à existência concreta do homem, a experiência do corpo, do desejo e da linguagem é afirmada, num nível fundamental, como aquilo pelo que se pode reconhecer as limitações que esses saberes indicam do exterior:

Cada uma dessas formas positivas em que o homem pode aprender que é finito, somente lhe é dada sobre o fundo de sua própria finitude. Ora, esta não é a essência mais bem purificada da positividade, mas aquilo a partir do que é possível que ela apareça. O modo de ser da vida, e aquilo mesmo que faz com que a vida não exista sem me prescrever suas formas, me são dados, fundamentalmente, pelo meu corpo; o modo de ser da produção, o peso das suas determinações sobre minha existência, me são dados pelo meu desejo; e o modo de ser da linguagem, todo o rastro da história que as palavras fazem brilhar no instante em que se as pronuncia, e, talvez, mesmo num tempo mais imperceptível ainda, me são dados somente ao longo da tênue cadeia do meu pensamento falante. (MC, p. 326, grifos meus)

Ao se desdobrar sobre dois níveis, a análise arqueológica não procura afirmar uma diferença absoluta entre o que se pode conceber como a finitude empírica do homem, que é dada através dos conteúdos dos saberes empíricos (ao nível das positividades empíricas), e a experiência fundamental das determinações do corpo, do

arqueologia. O foco da seção III do capítulo IX é mostrar como, no saber moderno, o finito é pensado em relação a si mesmo e como isso é a condição de possibilidade para se pensar o homem. Nesse sentido, vale notar que o termo "sujeito" sequer aparece na seção III. - Com efeito, a passagem, citada acima, que afirma que os conteúdos do saber só podem ser conhecidos se ligados à finitude, pode nos levar a explicála através da remissão desta última à finitude do sujeito transcendental kantiano. Esta leitura ligaria a Crítica à constituição dos saberes empíricos da modernidade, fazendo daquela a condição de possibilidade destes. No entanto, basta lembrar que o sujeito (finito) kantiano não é dado na experiência (cf. MC, pp. 254, 256), para nos desviarmos dessa leitura.

${ }^{56}$ A longo das análises de cada duplo, Foucault serve-se dos termos "natureza" e "história" a fim de sintetizar as determinações das leis da vida, do trabalho e da linguagem. 
desejo e da linguagem. Ao contrário, trata-se de mostrar que nos dois níveis se encontra a mesma finitude, mas que em cada um ela aparece sob um aspecto diverso:

\begin{abstract}
No fundamento de todas as positividades empíricas e do que pode-se indicar como limitações concretas à existência do homem, descobre-se uma finitude - que num sentido é a mesma: ela é marcada pela espacialidade do corpo, pela abertura do desejo e pelo tempo da linguagem; e, no entanto, ela é radicalmente outra: aí o limite não se manifesta como determinação imposta ao homem do exterior (porque ele tem uma natureza ou uma história), mas como finitude fundamental que repousa somente sobre seu próprio fato e se abre sobre a positividade de todo limite concreto. (MC, p. 326, grifos meus)
\end{abstract}

Essa passagem, contudo, traz consigo uma consequência importante em relação ao que dissemos anteriormente. Como vimos, no nível das positividades, a "descoberta da finitude é instável” (MC, p. 325), ela não se fixa sobre si mesma uma vez que aparece junto com a suposta possibilidade de sua superação num tempo escatológico. No entanto, se as limitações dadas ao nível da positividade dos modos de ser da vida, da produção e da linguagem são as mesmas dadas pela experiência fundamental do corpo, do desejo e da linguagem, na direção inversa, essa experiência fundamental se encontra implicada nos conteúdos empíricos do saber. Nesse sentido, os limites atuais que esses conteúdos deixam ver e que consistem em autênticas determinações da existência concreta do homem não podem ser dissimulados pela promessa de uma superação possível. Assim, a partir desse envolvimento recíproco dos conteúdos do saber com uma experiência fundamental, pode-se afirmar que mesmo no nível das positividades a finitude só se refere a si mesma. E por essa razão Foucault afirma que, através dos conteúdos empíricos do saber, assim como no seu fundamento, descobre-se uma finitude que "num sentido é a mesma: ela é marcada pela espacialidade do corpo, pela abertura do desejo e pelo tempo da linguagem".

Mas se "num sentido ela é a mesma", o que significa dizer que ela é "radicalmente outra"? Com efeito, no saber moderno, a finitude humana se mostra de duas maneiras. Como ao nível das positividades só se tem acesso ao homem através da dispersão dos conteúdos empíricos que são "exteriores a ele e mais velhos que seu nascimento" (MC, p.324), a sua finitude se revela a partir dessa exterioridade enquanto a sua existência é determinada pelas leis da vida, do trabalho e da linguagem; em suma, enquanto o homem aparece como um objeto dado na natureza e na história. Em contraposição à maneira pela qual se revela nas positividades, pode-se dizer que, ao nível fundamental, a finitude humana se mostra a partir do seu "interior", quer dizer, pela experiência incontornável da determinação do corpo, do desejo e da linguagem. A 
arqueologia evidencia então que uma nova ideia da finitude está em jogo no saber. Não mais aquela que, no saber clássico, definia-se pela anterioridade da "relação negativa ao infinito" (MC, p. 327); trata-se agora de uma finitude que, tanto do exterior, quanto do interior, só se refere a si mesma. No primeiro caso, porque todos conteúdos empíricos do saber envolvem a experiência das limitações do corpo, do desejo e da linguagem; no segundo caso, porque a finitude que se revela nessa experiência é fundamental e "repousa somente sobre seu próprio fato e se abre sobre a positividade de todo limite concreto".

Com isso, vemos que a finitude é pensada a partir de si mesma no próprio campo das "positividades empíricas da vida, do trabalho e da linguagem (a partir das quais o homem destacou-se historicamente como figura de um saber possível)” (MC, p. 374). Ora, se toda essa análise sobre o estatuto da finitude se desdobra inteiramente em relação aos saberes empíricos da vida, do trabalho e da linguagem, de que maneira ela poderia se ligar a uma análise arqueológica do pensamento filosófico?

Com a análise da finitude moderna, Foucault mostra qual foi o solo arqueológico que propiciou o surgimento da reflexão filosófica antropológica que se desenvolveu a partir do início do século XIX. Segundo Foucault, "do cerne mesmo da empiricidade, indica-se a obrigação de subir, ou, como se quiser, de descer, até uma analítica da finitude, em que o ser do homem poderá fundar a positividade de todas as formas que lhe indicam que ele não é infinito" (MC, p. 326). Tratando-se, primeiro, de mostrar como a finitude se fixa em si mesma, Foucault não enunciava ainda esse problema que a filosofia se colocará. Esta "obrigação" de se colocar um problema de fundamentação é o que surge do reconhecimento de que os conteúdos empíricos do saber, que deixam ver as limitações da existência concreta do homem, são inteiramente ligados à experiência fundamental das determinações do corpo, do desejo e da linguagem. Nesse sentido, ao surgir como "figura da finitude" na positividade do saber, o modo de ser do homem se configura como o espaço epistemológico no qual toda essa analítica se desdobra. Logo, para Foucault, importa salientar "um primeiro caráter que essa analítica marcará o modo de ser do homem" (MC, p. 326); ou seja, o homem é um espaço epistemológico marcado pela

repetição - da identidade e da diferença entre o positivo e o fundamental: a morte que corrói anonimamente a existência cotidiana do ser vivo é a mesma que aquela, fundamental, a partir da qual se dá a mim mesmo minha vida empírica; o desejo, que liga e separa os homens na neutralidade do processo econômico é o mesmo a partir do qual toda coisa é para mim desejável; o tempo que transporta as linguagens aloja-se nelas e acaba por desgastá-las, é 
esse tempo que estende o meu discurso antes mesmo que eu o tenha pronunciado em uma sucessão que ninguém pode conter. De um extremo a outro da experiência, a finitude responde a ela mesma; ela é, na figura do Mesmo, a identidade e a diferença das positividades e do seu fundamento. (MC, p. 326, grifos meus)

$\mathrm{Na}$ medida em que as "reflexões sobre a vida, o trabalho e a linguagem [...] valem como analítica da finitude" (MC, p. 328), quer dizer, enquanto o modo de ser do homem surge, nessas reflexões, como o espaço em que o positivo é repetido no fundamental, o que a arqueologia mostra é que a reflexão filosófica sobre o homem encontra no campo empírico as condições arqueológicas da sua existência no saber moderno: a finitude fundamental do homem não é uma "invenção" da reflexão filosófica antropológica. Isto porque, ao nível arqueológico, a repetição do positivo no fundamental, que caracteriza o modo de ser do homem ${ }^{57}$, constitui o ponto de articulação, na configuração do saber moderno, entre a reflexão filosófica e as empiricidades. Tal repetição constitui a primeira camada do campo da antropologia, mas ela é a "matriz teórica de três outros segmentos teóricos" 58 no interior da qual se desenvolveu uma reflexão em que a fundamentação do saber em geral é da mesma ordem que o fundado, ou seja, da mesma ordem que os próprios conteúdos dos saberes empíricos da vida, do trabalho e da linguagem. Como afirma o filósofo:

É neste espaço tênue e imenso aberto pela repetição do positivo no fundamental que toda esta analítica da finitude - tão ligada ao destino do pensamento moderno - vai se desdobrar: é aí que se verá sucessivamente o transcendental repetir o empírico, o cogito repetir o impensado, o retorno da origem repetir o seu recuo; é aí que vai se afirmar a partir de si próprio um pensamento do Mesmo irredutível à filosofia clássica.” (MC, 326)

Se Foucault afirma que há um desdobramento sucessivo das repetições do positivo no fundamental, ressaltando assim uma diacronia no saber, a análise arqueológica não irá descrever como se deram as passagens de uma repetição à outra. Voltando-se sobre essa sucessão já completamente desdobrada, a arqueologia descreverá, numa dimensão sincrônica, uma certa sobreposição dessas repetições que

\footnotetext{
${ }^{57}$ A seguinte passagem de Mathieu Potte-Bonneville é esclarecedora e apresenta bem a dimensão em que se situa a análise arqueológica de Foucault: "a dualidade humana procede de uma verdadeira duplicação no espaço do saber; já que são as mesmas determinações biológicas, econômicas, linguísticas que são simultaneamente convocadas como objetos e quadro da experiência; [...] esta duplicação não deve ser explicada a partir do interior da consciência (examinando como a unidade do sujeito se difrata em consciência pura e consciência empírica), mas do exterior, a partir da distribuição anônima dos saberes e da sua redistribuição em torno de uma referência profunda à vida, ao trabalho, à linguagem: aí se atesta uma disposição fundamentalmente contingente e efêmera (e não a manifestação de uma essência do homem)." (Mathieu Potte-Bonneville. "Du sable à la bataille: Foucault avant 1968". In: Patrice Maniglier (org.). Le moment philosophique des années 1960 em France. Paris: PUF, 2011, p. 200)

${ }^{58}$ Philippe Sabot. Lire Les mots et les choses de Michel Foucault. Paris: PUF, 2006, p. 129.
} 
compõem a figura epistemológica complexa do homem no saber moderno. Não iremos aqui analisar passo a passo cada uma delas. Antes, a partir desta descrição, que acabamos de acompanhar, de como o homem se projeta no saber como "figura da finitude", procuraremos mostrar a crítica de Foucault à analítica da finitude tendo em mente o que afirma Gérard Lebrun:

\begin{abstract}
Foucault não está falando aqui em seu próprio nome: contenta-se em designar um lugar, em seu mapa arqueológico, à 'Finitude moderna'. [...] Foucault fala como arqueólogo e descreve a forma de Finitude que devia necessariamente corresponder à 'era do homem'. [...] Acontece, porém, que o arqueólogo deixe de lado sua neutralidade e emita um juízo - severo - sobre a analítica da finitude. Pois esse discurso gira no vazio. ${ }^{59}$
\end{abstract}

Ora, em vista da maneira como Foucault descreve o surgimento do homem no saber, por que a analítica da finitude "gira no vazio"? A crítica de Foucault à analítica da finitude não consiste em apontar as contradições ou a falsidade das teorias filosóficas, em nome de uma teoria que fosse "mais verdadeira". Antes, ele se dedica a mostrar que a própria configuração arqueológica do saber moderno que tornou possível esse tipo de reflexão a condena ao autoesgotamento. Como vimos, de uma maneira geral, a figura epistemológica do homem é marcada pela repetição, isto é, pela identidade e pela diferença entre o que é do nível das positividades e o que é do nível do fundamental. A reflexão filosófica antropológica, a fim de mostrar que o homem é o fundamento do saber em geral, buscará reduzir essa diferença constitutiva da figura do homem à identidade, desenvolvendo-se como aquilo que Foucault chama de um pensamento do Mesmo: "através do domínio do originário que articula a experiência humana com o tempo da natureza e da vida, com a história, com o passado sedimentado das culturas, o pensamento moderno se esforça por reencontrar o homem em sua identidade" (MC, p. 345). No entanto, ainda que essa reflexão reconheça a irredutibilidade da diferença, ela busca conduzi-la à identidade, colocando-se, portanto, "uma tarefa incessante que deve sempre ser retomada" (MC, p. 335).

"A epistémê clássica", diz Foucault, "articula-se segundo linhas que não isolam de nenhuma maneira um domínio próprio e específico do homem” (MC, p. 320). Na modernidade, contudo, se a arqueologia pode identificar esse domínio, ele não é o de uma "realidade espessa e primeira" (MC, p. 321) que apenas carecia de conceitos e métodos para apreendê-la. Ao contrário, tal como Foucault a descreve, a figura epistemológica do homem surge apenas a partir da série de conhecimentos empíricos

\footnotetext{
${ }^{59}$ Gérard Lebrun. "Transgredir a finitude”. In: A filosofia e sua história. São Paulo: Cosac Naify, 2006, p. 344 , grifos meus.
} 
que proliferam nas regiões do trabalho, da vida e da linguagem e que apontam para ele como que do exterior (suas palavras, seu organismo, os objetos que ele fabrica). Como afirma Patrice Maniglier, o “'Homem’ não é o objeto direto de alguma ciência unificada, mas antes o efeito de superfície da sobreposição dessas 'três empiricidades" "60. Assim, é certo que aquilo que tornou possível a reflexão antropológica foi o seu surgimento; no entanto, o que a torna, para Foucault, de certa maneira impossível, isto é, que a condena ao autoesgotamento, pode ser esclarecido se voltarmos a atenção para essa ambiguidade constitutiva da sua figura.

Como afirma Foucault, "em As palavras e as coisas, eu quis mostrar com quais peças e com quais pedaços o homem foi composto no fim do século XVIII e no começo do século XIX” (DE I, 39, p. 569). Assim, se o homem não surge no saber como um domínio especial da objetividade, é porque a sua figura só é projetada através dos conteúdos empíricos que lhe são exteriores, mas, sobretudo, anteriores a ele na medida em que, com o seu poder de se dar representações das coisas ${ }^{61}$, ele "só se descobre ligado a uma historicidade já feita" (MC, p. 341). Noutras palavras, são nos conhecimentos que deixam entrever as determinações da natureza e da história sobre a sua existência concreta, isto é, nos conteúdos empíricos no cerne dos quais a finitude humana aparece numa incontornável referência a si mesma, é que se encontra, segundo Foucault, a condição arqueológica para que o homem possa surgir no saber. Contudo, a dispersão que marca a configuração arqueológica do campo empírico de onde provêm esses conhecimentos, ou seja, o fato de que, no início do século XIX, "o trabalho, a vida, a linguagem adquiriram sua historicidade própria, na qual eles estavam entranhados" (MC, p. 340), isto coloca, de saída, a impossibilidade de que a figura do homem possa ser dotada de alguma identidade. Como diz Gilles Deleuze: "em [As palavras e as coisas], Foucault evoca constantemente a necessidade de distinguir dois tempos: [...] num sentido estrito, são as coisas, primeiramente, que recebem uma historicidade própria e o homem que se apropria dessa historicidade num segundo tempo" "62. Mas Foucault notará que "elas [as coisas] pertencem a um tempo que não tem as mesmas medidas nem os mesmos fundamentos que ele [o homem]" (MC, p. 341). Ou seja, a figura do homem é uma composição de fragmentos dispersos, de conhecimentos

\footnotetext{
${ }^{60}$ Patrice Maniglier. "The order of things". In: Christopher Falzon, Timothy O’Leary, Jana Sawicki (org.). A companion to Foucault. Blackwell Publishing, 2013, p. 112, grifos meus.

61 "Agora que os saberes empíricos como aqueles da vida, do trabalho e da linguagem escapam à sua lei, agora que se tenta definir fora do seu campo o modo de ser do homem, o que é a representação senão um fenômeno de ordem empírica que se produz no homem e que se poderia analisar como tal.” (MC, p. 374)

${ }^{62}$ Gilles Deleuze. Foucault. Paris: Les Éditions de Minuit, 2004, p. 135.
} 
que pertencem a séries temporais irredutíveis umas às outras, que surgiram numa configuração arqueológica que não dispõe de nenhum elemento que permita mostrar um espaço de coerência entre eles - como era o caso do papel desempenhado pelo Discurso no saber clássico, que tinha uma "força de organização sobre o mundo empírico".

Como diz Gérard Lebrun, "é dessa experiência que brota a analítica moderna da Finitude" ${ }^{\text {63 }}$, isto é, um tipo de reflexão filosófica que se desenvolve no interior do que, na disposição geral saber moderno, constitui o campo daquilo que Foucault chama de antropologia. Para essa reflexão, o homem, enquanto "figura da finitude", será a "matéria" sobre a qual ela irá se desenvolver. Mas, se por um lado, ela o encara na passividade de um ser determinado pela natureza e pela história, tal como ele se apresenta ao nível das positividades, por outro lado, ela, ao mesmo tempo, toma a experiência das determinações do corpo, do desejo e da linguagem, que repetem no nível fundamental aquelas que se dão ao nível das positividades, como aquilo que revela uma certa atividade do homem, já que ela consiste na abertura pela qual o conhecimento é possível. Assim, a analítica da finitude buscará a identidade do homem através de uma espécie de torção dos conteúdos empíricos que compõem a sua figura epistemológica, isto é, uma torção pela qual esses próprios conteúdos devem funcionar como meios de se estabelecer uma fundamentação filosófica do saber em geral. Na analítica da finitude, diz Foucault,

\begin{abstract}
mostrando que o homem é determinado, trata-se [...] de manifestar que o fundamento dessas determinações é o ser mesmo do homem em seus limites radicais; ela deve manifestar também que os conteúdos da experiência já são suas próprias condições, que o pensamento assombra de antemão o impensado que lhe escapa e que ele sempre está encarregado de reapreender; ela mostra como esta origem da qual o homem nunca é o contemporâneo lhe é ao mesmo tempo retirada e dada sob o modo da iminência: em suma, tratase sempre para ela de mostrar como o Outro, o Distante é também o mais Próximo e o Mesmo. (MC, p. 350)
\end{abstract}

Nesse sentido, uma vez que a figura epistemológica do homem não possui uma espessura própria, pois só se pode ter acesso a ele a partir dos conteúdos que lhe são “exteriores" e "anteriores", os quais indicam as suas determinações pela natureza e pela história; e, uma vez que, ligado desse modo à dispersão do campo empírico, ele só pode surgir como uma figura fragmentada; ao colocá-lo como o fundamento de todo saber, a analítica da finitude se desenvolve numa direção inversa à da ordem arqueológica que mostra como ele é uma figura derivada de uma disposição anônima do campo empírico

\footnotetext{
${ }^{63}$ Gérard Lebrun. "Transgredir a finitude”. In: A filosofia e sua história. São Paulo: Cosac Naify, 2006, p. 343.
} 
do saber. Assim, se a analítica da finitude, segundo Foucault, está fadada ao autoesgotamento, é porque ela é um tipo de reflexão que se desenvolve como se houvesse, ao nível dos conteúdos empíricos, a possibilidade de fundar filosoficamente o saber em uma figura que, de um ponto de vista arqueológico, só pôde surgir a partir do que esses mesmos conteúdos revelam como o seu Outro irredutível. Como diz Foucault:

\begin{abstract}
esse terreno obscuro, que facilmente se interpreta como uma região abissal na natureza do homem, ou como uma fortaleza singularmente trancafiada de sua história, lhe está ligado de outro modo; é-lhe, ao mesmo tempo, exterior e indispensável: um pouco a sombra projetada do homem surgindo no saber; um pouco a mancha cega a partir da qual é possível conhecê-lo. (MC, p. 337, grifos meus)
\end{abstract}

\title{
2. O século XX e o enigma do "ser da linguagem"
}

Se a crítica à antropologia é então elaborada a partir de uma perspectiva interna a esse campo, a partir de uma perspectiva externa a ele, Foucault ainda apresenta um elemento suplementar e decisivo para essa crítica, que concerne ao modo de ser da linguagem no saber moderno. É a partir desse elemento que poderemos apreender o cerne do diagnóstico do presente de As palavras e as coisas, isto é, aquilo mesmo para o que viemos apontando desde o início: o modo de coexistência da figura epistemológica do homem com um questionamento sobre o "ser da linguagem". Em outras palavras, o que deve aparecer é a articulação da ontologia histórica da linguagem com o diagnóstico do presente, de modo que essa articulação venha a arrematar a crítica à antropologia.

Vimos que o desaparecimento do Discurso é um acontecimento que atinge o nível arqueológico do saber e que ele marca o limiar da idade clássica à modernidade. Porém, esse acontecimento pode ser considerado como apenas um dos aspectos da descontinuidade que se instaura entre as duas épocas: o seu aspecto negativo. Como afirma Foucault:

É que toda a epistémê moderna - aquela que se formou por volta do fim do século XVIII e ainda serve de solo positivo ao nosso saber, aquela que constituiu o modo de ser singular do homem e a possibilidade de o conhecer empiricamente - toda essa epistémê estava ligada ao desaparecimento do Discurso e do seu reino monótono, ao deslizamento da linguagem para o lado da objetividade e a sua reaparição múltipla. (MC, p. 397, grifos meus)

A descontinuidade entre o saber clássico e o saber moderno não é portanto marcada apenas pelo desaparecimento do Discurso. Este acontecimento arqueológico está ligado fundamentalmente a um outro (cf. MC, p. 318), quer dizer, a passagem para 
a modernidade compreende também tudo o que Foucault condensa na expressão "o retorno da linguagem" (MC, p. 314) e que pode ser considerado como um dos traços positivos dessa descontinuidade: trata-se da objetivação da linguagem pela filologia e da sua multiplicação em modalidades diversas, para além do seu estatuto de objeto de ciência.

De maneira análoga ao que se passou no saber clássico, no qual a linguagem, enquanto Discurso, mostrava um desnível epistemológico em relação às outras empiricidades; no saber moderno, ela também terá um caráter peculiar. Se, a partir do momento em que o Discurso desaparece, uma nova configuração do campo empírico do saber se instaura, sendo marcada por uma dispersão fundamental, no que diz respeito particularmente à região da linguagem, a arqueologia mostra que aí essa dispersão se duplica. Como afirma Foucault, as diversas transformações a partir das quais o campo empírico do saber se configura na modernidade evidenciam que a região da linguagem apresenta, "senão um privilégio, ao menos um destino que se mostra singular quando o comparamos àquele do trabalho ou da vida" (MC, p. 315). Por um lado, os seres vivos e os processos econômicos convergiram para algo como um princípio de sua inteligibilidade, isto é, para a vida e para o trabalho:

quando o quadro da história natural foi dissociado, os seres vivos não foram dispersados, mas, ao contrário, reagrupados em torno do enigma da vida; quando a análise das riquezas desapareceu, todos os processos econômicos se reagruparam em torno da produção e do que a tornava possível. (MC, p. 315)

Por outro lado, o fato de que, com o surgimento da filologia no início do século XIX, a linguagem se torne "um domínio singular da objetividade" (MC, p. 309), cuja inteligibilidade é procurada na espessura histórica das palavras [no "gramatical puro"], este fato não constitui senão um caso particular com relação a tudo o que se passa com a linguagem a partir dessa época:

\footnotetext{
destacada da representação, a linguagem não existe mais doravante, $e$ ainda até nós, senão sob um modo dispersado; [...] quando a unidade da gramática geral - o discurso - se dissipou, então a linguagem apareceu segundo modos de ser múltiplos, cuja unidade, sem dúvida, não podia ser restaurada. (MC, p. 316 , grifos meus)
}

Quanto ao que foi essa dispersão que caracteriza o modo de ser da linguagem na modernidade, Foucault a resume da seguinte maneira:

Para os filólogos, as palavras são como tantos objetos constituídos e depositados pela história; para aqueles que querem formalizar, a linguagem deve despojar seu conteúdo concreto e não mais deixar aparecer senão as formas universais do discurso; se se quer interpretar, então as palavras se tornam texto a fraturar para que se possa ver emergir em plena luz este outro 
sentido que elas escondem; enfim, acontece à linguagem de surgir por ela mesma em um ato de escrever que não designa nada de mais senão a si mesmo [isto é, como literatura]. (MC, p. 315)

Se, com o surgimento da filologia, das novas técnicas de formalização e de interpretação, assim como da literatura (da "literatura como tal" (MC, p. 313), como dirá Foucault); se houve, assim, uma “dispersão" da linguagem no saber moderno, é em contraposição à sua unidade no saber clássico, ao seu estatuto de Discurso, que ela aparece. Mas além de perder a unidade, com todas as modalidades que a linguagem assume em cada um desses casos, ela perde também o caráter "discreto" que possuía no saber clássico, a sua "transparência", enquanto ela era apenas um instrumento do conhecimento. A dispersão da linguagem mostra que, no saber moderno, esta possui uma espessura própria, que ela não mais se identifica com o pensamento, mas que é explorada em direções diversas.

Dirá Foucault que "o fracionamento da linguagem, contemporâneo da sua passagem à objetividade filológica, não seria então senão a consequência mais recentemente visível (porque a mais secreta e a mais fundamental) da ruptura da ordem clássica” (MC, p. 318, grifos meus). Entretanto, não é somente a demarcação dessa ruptura que interessa a Foucault quando ele descreve a dispersão da linguagem a partir da sua "expansão múltipla” (MC, p. 314), que eclodiu no início do século XIX. Para o arqueólogo, por definir o modo de ser da linguagem na modernidade, a importância deste acontecimento também consiste em lançar luz sobre a sua própria época. Neste sentido, é preciso que o levemos em conta, para que possamos apreender o diagnóstico do presente de As palavras e as coisas: se esse diagnóstico mostra o modo de coexistência do homem com a linguagem, e "o homem", nesta formulação, corresponde à sua figura epistemológica e ao tipo de reflexão filosófica que ela tornou possível, "a linguagem" corresponde justamente a essa dispersão, que caracteriza o seu modo de ser moderno, e ao que este tornou possível no saber.

De fato, a dispersão da linguagem se deu no início do século XIX, porém, de um ponto de vista arqueológico, foi ela que tornou possível o aparecimento, apenas a partir do fim deste século, do que se pode considerar como um segmento do saber moderno, cujo foco das questões é o próprio "ser da linguagem". Segundo a maneira que Foucault o apresenta, trata-se de um questionamento bastante diversificado e que não é próprio de uma "ciência" ou de uma "filosofia" particulares. Isto é o que podemos ver na seguinte passagem, na qual Foucault faz um apanhado de quais questões seriam essas: 
O que é a linguagem? O que é um signo? Isto que é mudo no mundo, nos nossos gestos, em todo brasão enigmático de nossas condutas, nos nossos sonhos e nossas doenças - tudo isso fala, e qual linguagem o sustenta, segundo qual gramática? Tudo é significante, ou o quê, e para quem e segundo quais regras? Qual relação há entre a linguagem e o ser, e é mesmo ao ser que sempre se dirige a linguagem, aquele, ao menos, que fala verdadeiramente? O que é então esta linguagem, que não diz nada, não se cala jamais e se chama 'literatura'? (MC, p. 317)

No entanto, frente a essa diversidade de questões, Foucault identifica um traço comum que as perpassa, um traço que, como veremos mais adiante, ganha um grande potencial crítico em As palavras e as coisas: tais questões têm como horizonte conduzir a linguagem a uma unidade que ela perdeu desde que o Discurso desapareceu. Bem entendido, não se trata de afirmar com isso que esse questionamento procuraria fazer com que a linguagem restituísse o modo de ser que a caracterizava na idade clássica, isto é, fazer com que ela voltasse a ser transparente à representação e funcionasse como um instrumento do conhecimento; trata-se, então, de apontar que todas essas questões buscam pensar aquilo que, para Foucault, é o "ser da linguagem". Segundo o arqueólogo, sobre o fundo da dispersão da linguagem, tal horizonte foi indicado por Nietzsche e Mallarmé, ou seja, são os trabalhos desses autores que instauraram no saber moderno esse espaço de questionamento no interior do qual "a linguagem surge segundo uma multiplicidade enigmática que é preciso dominar” (MC, p. 316). Em vista disso, Foucault ressalta que, na sua época, aquelas questões passaram a ser não só possíveis, mas elas se impuseram de uma maneira necessária:

elas se tornaram possíveis pelo fato de que, no início do século XIX, estando a lei do discurso destacada da representação, o ser da linguagem achou-se como que fragmentado; mas elas se tornaram necessárias quando, com Nietzsche, com Mallarmé, o pensamento foi reconduzido, e violentamente, à própria linguagem, ao seu ser único e difícil. (MC, p. 317)

Ora, se o homem é uma figura moderna, chama a atenção nesta passagem que Foucault descreva esse espaço de questões, com as quais lidaram várias experiências teóricas e literárias a partir do fim do século XIX, simplesmente passando ao largo do campo da antropologia. Isto é, na disposição geral do saber moderno, neste espaço não se trata de se perguntar "o que é o homem?", pergunta que, todavia, "percorre[u] o pensamento desde o início do século XIX' (MC, p. 352, grifos meus). E o arqueólogo demarca a separação entre o campo da antropologia e o espaço de questionamento sobre o "ser da linguagem", ao enfatizar que este último é, de longe, o mais premente em sua época. Uma separação que ele apresenta através de um diálogo fictício entre Nietzsche e Mallarmé: 
A grande tarefa à qual se dedicou Mallarmé, e até a morte, é ela que nos domina agora; no seu balbucio, ela envolve todos nossos esforços de hoje para trazer de volta à coação de uma unidade talvez impossível o ser fragmentado da linguagem. O empenho de Mallarmé para encerrar todo discurso possível na frágil espessura da palavra, nesta fina e material linha preta traçada à tinta sobre o papel, responde, no fundo, à questão que Nietzsche prescrevia à filosofia. Para Nietzsche, não se tratava de saber o que eram em si mesmos o bem e o mal, mas quem era designado, ou antes, quem falava quando, para designar-se a si próprio, dizia-se Agathos, e Deilos para designar os outros. Pois é aí, naquele que toma o discurso e, mais profundamente, detém a palavra, que a linguagem se reúne completamente. A esta questão: quem fala? Mallarmé responde e não cessa de retomar sua resposta dizendo que o que fala é, em sua solidão, em sua vibração frágil, em seu nada, a própria palavra - não o sentido da palavra, mas seu ser enigmático e precário. Enquanto Nietzsche mantinha até o fim a interrogação sobre aquele que fala, certo de, ao final, irromper ele mesmo no interior deste questionamento para fundá-lo sobre si mesmo, sujeito falante e interrogante: Ecce homo - Mallarmé não cessa de se apagar na sua própria linguagem, a ponto de não mais querer figurar aí senão a título de executor numa pura cerimônia do Livro em que o discurso se comporia de si mesmo. É bem possível que todas as questões que atravessam atualmente nossa curiosidade [...], que todas essas questões se coloquem hoje na distância jamais preenchida entre a questão de Nietzsche e a resposta que lhe deu Mallarmé. [...] Toda a curiosidade do nosso pensamento se aloja agora na questão: o que é a linguagem, como contorná-la para fazê-la aparecer em si mesma e em sua plenitude? (MC, pp. 316-317, grifos meus)

Aqui, portanto, reencontramos aquela distância ou "abertura" [béance] que, como apontamos na introdução deste trabalho, nas palavras de Foucault, é "aquela na qual justamente nós existimos e nós falamos" (MC, p. 350). Essa "abertura", que Foucault descreve nos meados do século XX, é ainda mais notável se lembrarmos que, assim como a dispersão da linguagem que tornou possível o questionamento sobre o seu ser, o surgimento do homem no saber também é um aspecto positivo da descontinuidade com a ordem clássica. Como é dito no contexto da descrição de um dos segmentos teóricos do campo da antropologia: "o limiar da nossa modernidade não está situado no momento em que se quis aplicar ao estudo do homem métodos objetivos, mas no dia em que se constituiu um duplo empírico-transcendental a que se chamou homem" (MC, p. 330). Assim, segundo Foucault, o surgimento do homem no saber é coetâneo deste acontecimento que foi a dispersão que define o modo de ser da linguagem. Ou seja, com o desaparecimento do Discurso, o homem e o "ser fragmentado da linguagem" passam a coexistir no saber desde o início da modernidade:

O homem fora uma figura entre dois modos de ser da linguagem; ou antes, ele se constituiu somente no tempo em que a linguagem, depois de ter sido alojada no interior da representação e como que dissolvida nela, só se liberou dela se fragmentando: o homem compôs sua própria figura nos interstícios de uma linguagem em fragmentos. (MC, p. 397) 
A modernidade, portanto, de um ponto de vista arqueológico, não é apenas a "idade do homem". Mais do que isso, é a época em que, pela primeira vez, o homem coexiste com a linguagem. Numa passagem que citamos na "Introdução", Foucault afirmava que, diante dessa coexistência, a única certeza de que a análise arqueológica pode assegurar é que "jamais na cultura ocidental o ser do homem e o ser da linguagem puderam coexistir e se articular um com o outro" (MC, p. 350, grifos meus). Sendo assim, frente a essa coexistência, todo o problema consistiria na possibilidade dessa articulação, isto é, na possibilidade de haver uma reflexão sobre o ser do homem que fosse, ao mesmo tempo, uma reflexão sobre o "ser da linguagem". A "prudência" do arqueólogo, como vimos, leva-o a afirmar que "nada pode nos dizer de antemão de qual lado a via está aberta” (MC, p. 350), ou seja, se essa possibilidade irá se realizar ou não.

De todo modo, diante da constatação da coexistência do homem com a linguagem, podemos ver como o diagnóstico do presente de As palavras e as coisas se ampara, em larga medida, na ontologia histórica da linguagem. Mas, se essa coexistência se mostra como o elemento central do que Foucault nos diz sobre a sua época, deixaríamos escapar o teor desse diagnóstico, se ignorarmos que ele se articula com a crítica à antropologia. Se, por um lado, Foucault realiza essa crítica descrevendo a formação interna do campo da antropologia e mostrando o autoesgotamento do tipo de reflexão que aí se desenvolve, por outro lado, a partir de uma perspectiva externa a esse campo, que o situa na disposição geral do saber moderno, ele arremata essa crítica à antropologia ao mostrar que aquilo que possibilitou o surgimento do homem também possibilitou o que colocará a sua existência em questão. Quer dizer, embora $o$ questionamento sobre o ser da linguagem só tenha se imposto de forma necessária quase um século depois de ela ter se dispersado (o que o tornou possível), com o desaparecimento do Discurso; o saber moderno se constituiu, desde o início, sob uma tensão entre o homem e o modo de ser disperso da linguagem. Uma tensão que, todavia, permaneceu latente e que só irrompe no saber moderno a partir do século XX, depois que, com Nietzsche e Mallarmé, instaurou-se um campo de questionamento sobre o "ser da linguagem".

Embora Foucault afirme que a arqueologia não pode decidir acerca do desfecho desse "capítulo" da história do saber que se inicia no fim do século XVIII (rompimento ou conciliação?), o conjunto das análises não dissimula a aposta do arqueólogo. A relevância dada ao "retorno da linguagem" e ao espaço de questionamento sobre o seu ser se contrapõe claramente à insistência sobre o esgotamento do tipo de reflexão que 
aparece no campo da antropologia. Nesse sentido, se, em meados do século XX, Foucault afirma que esta constitui um solo para a reflexão filosófica em relação ao qual “em grande parte nós ainda não nos desprendemos", o modo como são apresentadas as tentativas de se "reconstituir a unidade perdida da linguagem" (MC, p. 318), que animam nessa mesma época o espaço de questionamento sobre o seu ser, apontam para o rompimento. A antropologia faz parte da história do saber moderno e isso não se pode negar, mas Foucault procurou mostrar que ela foi apenas uma Dobra do saber, que na sua época já se "desdobra". E esse desdobramento é justamente aquele de um pensamento sobre o "ser da linguagem", que, ao mesmo tempo, é uma abertura de possibilidades no saber moderno:

Se essa mesma linguagem surge agora com uma insistência cada vez maior numa unidade que nós devemos mas ainda não podemos pensar, não seria o signo de que toda essa configuração vai agora balançar, e que o homem está em via de perecer, na medida em que brilha mais forte no nosso horizonte o ser da linguagem? Tendo o homem se constituído quando a linguagem estava condenada à dispersão, não vai ele ser dispersado quando a linguagem se reúne? E se isso fosse verdade, não seria um erro - um erro profundo, já que ele nos esconderia o que é preciso pensar agora - interpretar a experiência atual como uma aplicação das formas da linguagem à ordem do humano? Não seria preciso, antes, renunciar a pensar o homem, ou, para ser mais rigoroso, pensar mais de perto este desaparecimento do homem - e o solo de possibilidade de todas as ciências do homem - na sua correlação com a nossa inquietude com a linguagem? [...] Certamente, não se trata aí de afirmações, quando muito de questões às quais não é possível responder; é preciso deixálas em suspenso aí onde elas se colocam, sabendo apenas que a possibilidade de as colocar abre, sem dúvida, para um pensamento futuro. (MC, pp. 397398 , grifos meus) 


\section{Considerações finais}

Como afirma Sabot, "a coerência do conjunto da construção arqueológica de Foucault", em As palavras e as coisas, mostra-se pelos seus "efeitos de simetria cuidadosamente manejados" ${ }^{\prime 64}$. Apresentando o que consideramos ser o diagnóstico do presente que esta obra realiza, vimos como ele pode vir à tona se voltamos nossa atenção para esses "efeitos" que, em larga medida, são produzidos pelas comparações entre as diferentes ordens do saber que o arqueólogo descreve. Procuramos, então, mostrar como os termos que compõem esse diagnóstico despontam na ordem do saber moderno a partir do desaparecimento do Discurso; isto é, que a figura epistemológica do homem e um questionamento sobre o "ser da linguagem", que tem como horizonte conduzir a uma unidade a dispersão na qual ela se apresenta, surgiram com a transformação de duas características maiores da linguagem clássica: do seu "funcionamento" que permitia fundar o jogo das análises e das sínteses das representações no seu próprio espaço e da sua unidade. Mas procuramos mostrar, também, que esse diagnóstico de fato aparece quando, uma vez constatada a coexistência do homem com a linguagem na disposição geral do saber moderno, Foucault aponta para o que consideramos como uma tensão no cerne desse saber. Uma tensão que, tal como ele deixa entender, existiu de uma forma latente desde o início da modernidade; assim, se esse questionamento sobre o "ser da linguagem" é capaz de "ameaçar" a existência do homem, esta sempre esteve comprometida, pois o que tornou possível tal questionamento foi um acontecimento (a dispersão da linguagem) que se deu ao mesmo tempo que ela. Nesse sentido, esse diagnóstico se articula tanto com uma crítica à antropologia, quanto com esta espécie de ontologia histórica da linguagem que Foucault realiza em As palavras e as coisas.

Se Foucault insiste, por um lado, que o tipo de reflexão que se tornou possível com o surgimento da figura epistemológica do homem (a "analítica da finitude") estava fadada ao autoesgotamento, por outro lado, quando ele descreve, a partir de uma perspectiva que visa à disposição geral do saber moderno, a "ameaça" que o questionamento sobre o "ser da linguagem" faz à existência dessa figura, ele mobiliza a ideia de uma "unidade" da linguagem que estaria no horizonte desse questionamento,

\footnotetext{
${ }^{64}$ Philippe Sabot. Le Même et l'Ordre - Michel Foucault et le savoir à l'âge classique. Lyon: ENS Éditions, 2015, p. 55.
} 
uma unidade que "nós devemos mas ainda não podemos pensar". Embora ao final de $A s$ palavras e as coisas a ideia dessa unidade apareça de uma maneira um tanto enigmática, no início da obra, Foucault parece nos dar algumas pistas para que possamos compreender, ao menos um pouco, o que pode ser esse horizonte que, uma vez alcançado, consumaria o desaparecimento do homem. A primeira pista diz respeito a existência da linguagem.

Como vimos, a natureza dos signos no saber da Renascença "constrange a linguagem a residir do lado do mundo, em meio às plantas, às ervas, às pedras e aos animais" (MC, p. 50). Foucault nos mostrava que, fazendo parte do sistema das assinaturas a mesmo título que os signos naturais, pode-se considerar que a linguagem era uma coisa em meio às outras coisas da natureza, o que o levava a dizer que, nesta época, a linguagem existe. "A partir do século XVII, é esta existência massiva e intrigante da linguagem que se acha elidida" (MC, p. 93): com a transformação da natureza dos signos, cujo maior testemunho Foucault identificava na Lógica de PortRoyal, isto é, com o fato de que a partir de então os signos não mais se definirão como uma relação entre figuras da semelhança que se encontravam dadas no mundo, mas como a ligação entre duas ideias, em suma, a partir do momento em que os signos se recolhem no espaço da representação para aí se articularem com o conhecimento, Foucault dirá que:

no limite, [...] a linguagem clássica não existe. [...] Ela funciona: toda a sua existência se acomoda no seu papel representativo, aí se limita com exatidão e acaba por aí se esgotar. A linguagem não tem mais outro lugar senão a representação, nem outro valor senão nesta.” (MC, p. 93, grifos meus).

Procuramos mostrar qual era a importância deste funcionamento da linguagem no saber clássico e de que maneira ela, que, assim como a linguagem na Renascença, estava submetida ao sistema dos signos em geral, definiu-se como Discurso, quando a natureza dos signos se transformou no século XVII. No entanto, para Foucault, a importância desta transformação não se limita ao que, a partir dela, pode-se compreender do saber clássico. Segundo o arqueólogo, as suas consequências alcançam a sua própria época, já que ela consistiu numa:

imensa reorganização da cultura, da qual a idade clássica foi a primeira etapa, a mais importante talvez, já que ela é responsável pela nova disposição na qual nós ainda estamos presos - já que ela é que nos separa de uma cultura em que a significação dos signos não existia, pois ela estava absorvida na soberania do Semelhante; mas onde seu ser enigmático, monótono, obstinado, primitivo, cintilava numa dispersão ao infinito." (MC, p. 58 , grifos meus) 
Com isso, Foucault nos fornece uma outra pista que se articula à primeira. Ou seja, o problema da existência e da "inexistência" da linguagem parece se desdobrar e corresponder a uma outra oposição que, sem dúvida, para nós, soa um tanto estranha. Trata-se da oposição entre um modo de ser da linguagem que não está submetido a significação e um outro que ela assume quando entra no que se pode considerar como a sua era da significação, que se inicia na idade clássica e se estende até os nossos dias. Ora, mas o que pode ser uma linguagem que não significa?

Em poucas palavras, uma linguagem que não significa, como é o caso, segundo Foucault, da linguagem na Renascença, é uma linguagem que, antes de tudo, é dotada de "propriedades" e "virtudes". Vimos que, nesta época, a linguagem é "coisa opaca" que se liga a todas as outras coisas por uma rede de semelhanças preestabelecidas por Deus. Porém, como insiste Foucault, esta não é uma característica própria de uma linguagem esotérica, mas de toda linguagem, de modo que, para os gramáticos renascentistas, ela "não é o que é porque ela tem um sentido. [...] As palavras agrupam sílabas e as sílabas, letras, porque há, depositadas nestas, virtudes que as aproximam e as desassociam, exatamente como no mundo as marcas se opõem ou se atraem umas às outras" (MC, p. 50). Na Renascença, portanto, a trama das semelhanças suplanta a função significativa da linguagem. Nesse sentido, numa outra passagem, Foucault nos dirá de uma "função simbólica" da linguagem:

Claude Duret observa que os hebreus, os cananeus, os samaritanos, os caldeus, os sírios, os egípcios, os púnicos, os cartagineses, os sarracenos, os turcos, os mouros, os persas, os tártaros escrevem da direita para a esquerda, seguindo assim 'o curso e movimento diário do primeiro céu, que é muito perfeito, conforme a opinião do grande Aristóteles, aproximando-se da unidade'; os gregos, os georgianos, os maronitas, os jacobitas, os coftitas, os tzvernianos, os posnanianos e, certamente, os latinos e todos os europeus escrevem da esquerda para a direita, seguindo 'o curso e movimento do segundo céu, conjunto dos sete planetas'; os indianos, os catânios, os chineses, os japoneses escrevem de cima para baixo, conforme 'a ordem da natureza, que deu aos homens a cabeça no alto e os pés embaixo'; 'ao contrário dos supracitados', os mexicanos escrevem quer de baixo para cima, quer em 'linhas espirais, como as que o Sol faz em seu curso anual sobre o Zodíaco'. E assim, 'por esses cinco diversos modos de escrever, os segredos e mistérios da janela do mundo e da forma da cruz, conjunto da redondeza do céu e da terra, são propriamente denotados e expressos'. As línguas estão com o mundo numa relação mais de analogia que de significação; ou, antes, seu valor de signo e sua função de duplicação se sobrepõem; elas dizem o céu e a terra de que são a imagem; reproduzem, na sua mais material arquitetura, a cruz cujo advento anunciam - esse advento que, por sua vez, se estabelece pelas Escrituras e pela Palavra. Há uma função simbólica na linguagem: mas, desde o desastre de Babel, não devemos mais buscá-la senão em raras exceções - nas próprias palavras, mas antes na existência mesma da linguagem, na sua relação total com a totalidade do mundo, no entrecruzamento de seu espaço com os lugares e as figuras do cosmos. (MC, p. 52) 
Assim, se, para Foucault, a partir do século XVII, a linguagem entra no que se pode considerar como a sua era da significação, é porque toda esta preocupação com a sua existência desapareceu. O que o leva a dizer que o "ser bruto da linguagem - esta massa de signos depositados no mundo para aí exercer nossa interrogação - se apagou" (MC, p. 109). Ou seja, se na Renascença esse "ser bruto da linguagem", que manifestava sua existência própria na forma da escrita, intrigava, na medida em que, diante dele, cumpria desvelar as suas "virtudes" e "propriedades", tal como diante de todas as outras coisas do mundo; na idade clássica, com a transformação do modo de ser da linguagem, que se fez acompanhar do desaparecimento de tal "privilégio absoluto da escrita", o problema que se colocava era o de saber de que maneira ela analisa o pensamento. Toda a atenção da reflexão clássica atravessava a existência das palavras, o seu "ser bruto", para se concentrar completamente no que elas significavam. Como vimos, no saber clássico não se podia dizer que a linguagem era propriamente um objeto para a gramática geral, pois, no fundo, ela era uma teoria da representação, e, na medida em que esta é representada por signos verbais, uma teoria do Discurso. Nas palavras de Foucault, "a análise da linguagem, de Lancelot a Destutt de Tracy, faz-se a partir de uma teoria abstrata dos signos verbais e na forma de uma gramática geral: mas ela sempre toma por fio condutor o sentido das palavras" (MC, pp. 80-81, grifos meus). Assim, se a idade clássica é "responsável pela nova disposição na qual nós ainda estamos presos", é porque, ainda que a linguagem tenha se separado da representação; ainda que, com o surgimento da filologia, a "composição gramatical [passe a ter] regularidades que não são transparentes à significação do discurso" (MC, p. 295); em suma, ainda que, na modernidade, ela ganhe enfim um estatuto de objeto; a despeito de tudo isso, a linguagem é visada em sua "estrutura significante" pela maioria (senão todas) as experiências teóricas que dela se ocupam. E como Foucault dirá em $A$ arqueologia do saber, esclarecendo o que acompanhamos em As palavras e as coisas, ao visar unicamente esta estrutura, deixa-se de lado a sua dimensão de existência:

\footnotetext{
a estrutura significante da linguagem remete sempre para outra coisa; os objetos aí se acham designados; o sentido aí é visado; o sujeito aí é referido por um certo número de signos, mesmo se aí ele não está presente em si mesmo. A linguagem parece sempre povoada pelo outro, pelo alhures, pelo distante, pelo longínquo; ela é cavada pela ausência. Não é ela o lugar de aparição de outra coisa que si mesma, e nesta função, sua própria existência não parece se dissipar? (AS, p. 145)
}

No entanto, se na idade clássica a existência da linguagem foi completamente dissolvida no seu funcionamento significativo, na modernidade, quando ela se dispersa, 
não são todas as suas modalidades que se submetem a essa "estrutura significante". Daí a grande importância que Foucault atribui à literatura. Como ele afirma: "a literatura é a contestação da filologia (da qual, todavia, ela é a figura gêmea): ela conduz a linguagem da gramática ao desnudado poder de falar e, aí, ela reencontra o ser selvagem e imperioso das palavras" (MC, p. 313). Foucault se volta para a literatura não como um crítico literário, mas para mostrar que ela é, no saber moderno, o lócus privilegiado do reaparecimento ("ainda que de uma maneira mais alusiva e diagonal que direta" (MC, $\mathrm{p}$. 58) do "ser da linguagem", isto é, onde a linguagem não é apenas um meio de expressão do sentido que ela enuncia, mas onde a sua existência se apresenta como uma coisa dada no mundo:

\begin{abstract}
pode-se dizer, num sentido, que a 'literatura', tal como se constituiu e se designou enquanto tal no limiar da idade moderna, manifesta a reaparição, aí onde não o esperávamos, do ser vivo da linguagem. [...] Ao longo de todo o século XIX e até nós ainda - de Hölderlin à Mallarmé, à Antonin Artaud - a literatura só existiu em sua autonomia, só se desprendeu de qualquer outra linguagem por um corte profundo, formando um tipo de 'contra-discurso' e remontando, assim, da função representativa ou significante da linguagem à este ser bruto esquecido desde o século XVI. [...] Na modernidade, a literatura é o que compensa (e não o que confirma) o funcionamento significativo da linguagem. Através dela, o ser da linguagem brilha novamente nos limites da cultura ocidental - e no seu cerne -, pois ele é, desde o século XVI, o que lhe é mais estranho; mas, desde esse mesmo século, ele está no centro do que ela recobriu" (MC, p. 59)
\end{abstract}

Assim, a oposição "inexistência"-existência, que se estabelece a partir do momento em que a linguagem entra na sua era da significação, parece corresponder a uma outra oposição que se encontra no cerne do saber moderno, isto é, àquela que opõe uma modalidade transitiva à uma modalidade intransitiva da linguagem, cujo maior testemunho é dado pela literatura. Guillaume le Blanc esclarece isso de um modo sintético, que vale acompanhar:

\begin{abstract}
A lição maior da experiência literária segundo Foucault pode [...] se resumir da seguinte maneira: o 'palavra à palavra' ao invés de um retorno às coisas. [...] O 'palavra à palavra' da literatura abre para uma experiência da linguagem que só reenvia à ela mesma. A literatura moderna avança assim como o que não tem 'nada a dizer nem a ver'. Não ter 'nada a dizer nem a ver', para a literatura, não é não ter nada a escrever, mas recolocar em questão a ideia de uma anterioridade das coisas em relação as palavras, assim como de um possível acesso às coisas a partir das palavras. As palavras são sempre palavra à palavra e não palavras para as coisas ou palavras a partir das coisas. ${ }^{65}$
\end{abstract}

Não poderíamos, então, considerar que a noção de "ser da linguagem" (que traz consigo todo o peso que a tradição filosófica atribui a palavra "ser") não seria, no fundo,

\footnotetext{
${ }^{65}$ Guillaume le Blanc. La pensée Foucault. Paris: Ellipses Édition, 2006, p. 55.
} 
uma maneira de designar algo que de tão patente escapa ao nosso olhar, isto é, o fato bruto de que há linguagem? Dito de outro modo, este "ser da linguagem", que Foucault diz ter "reaparecido" no saber moderno, quando a linguagem se separou da representação, não seria uma forma de nomear a existência da linguagem que, em sua unidade, constitui o ponto do qual emanam e para o qual convergem todas as experiências teóricas e literárias que a colocam em questão, mas que, principalmente as primeiras, deixam escapar na medida em que se atêm à sua transitividade?

É interessante notar que essa questão da irredutibilidade da linguagem e, de um modo mais geral, dos signos à um "funcionamento significativo" também aparece nas considerações de Foucault sobre a pintura. Em 1966, Foucault afirmava a Claude Bonnefoy, que o perguntava qual quadro contemporâneo ilustraria o pensamento não dialético da sua época, que "é a pintura de Klee que representa melhor, com relação a nosso século, o que pôde ser Velasquez com relação ao seu” (DE I, 39, p. 572). Retomando essa comparação, em 1967, Foucault afirma:

\footnotetext{
Eu continuo a considerar que esta oposição é válida. Klee é aquele que tomou da superfície do mundo toda uma série de figuras que valiam como signos e que as orquestrou no interior do espaço pictural deixando a sua forma e a sua estrutura de signos, em suma, mantendo seu modo de ser de signos e fazendo-os funcionar ao mesmo tempo de maneira a não ter mais significação. E o que há em mim de não estruturalista, de não linguista se extasia face a uma tal utilização dos signos: ou seja, do signo em seu modo de ser de signo, e não em sua capacidade de fazer aparecer sentido" (DE I, 50, p. 642, grifos meus)
}

Com tudo isso pretendemos, apenas, trazer à baila alguns elementos que, talvez, possam ajudar a elucidar o que seria o horizonte do questionamento sobre o "ser da linguagem”. Segundo Foucault, este se impôs de uma maneira necessária no fím do século XIX, com os trabalhos de Nietzsche e Mallarmé e ele constitui o espaço das questões mais prementes para a sua época. Sem dúvida, seria preciso analisar mais a fundo o trabalho desses autores para que possamos compreender melhor o que Foucault quer dizer com a ideia de um pensamento que buscaria reconduzir a dispersão da linguagem a uma unidade. Chama a atenção, no entanto, que a despeito do privilégio que Foucault atribui, ao final de As palavras e as coisas, à etnologia (de Lévi-Strauss) e à psicanálise (de Lacan), mas também à linguística, na medida em que ela daria às duas primeiras o seu "modelo formal" (MC, p. 392), de modo que as três são descritas como "contra-ciências" (MC, p. 391) humanas, pela sua posição na configuração do saber moderno que passa ao largo do campo da antropologia; chama a atenção que, a despeito disso, Saussure, que era contemporâneo de Nietzsche e Mallarmé, não tenha sido 
apontado por Foucault como um dos instauradores do espaço de questionamento sobre o "ser da linguagem". No entanto, se nos voltarmos para as três passagens que, em $A s$ palavras e as coisas, o linguista é mencionado, logo vemos que, para Foucault, o projeto saussuriano de uma "semiologia geral" retoma toda a problemática da natureza do signo tal como ela fora desenvolvida a partir da Lógica Port-Royal e que fora suspensa a partir do início do século XIX, com o surgimento da filologia e o estudos da evolução histórica das línguas. Leiamos essas passagens:

\begin{abstract}
era mesmo necessário que [...], reencontrando, o projeto de uma semiologia geral, Saussure desse ao signo uma definição que pôde parecer 'psicologista' (ligação de um conceito com uma imagem): é que, de fato, ele redescobria aí a condição clássica para pensar a natureza binária do signo.” (MC, p. 81, grifos meus)
\end{abstract}

foi preciso justamente que Saussure contornasse este momento da fala [parole] que foi capital para toda filologia do século XIX, para restaurar, para além das formas históricas, a dimensão da língua [langue] em geral, e reabrir, através de tanto esquecimento, o velho problema do signo, que animara todo pensamento, sem interrupção, desde Port-Royal até os últimos Ideólogos.” (MC, p. 299, grifos meus)

sabe-se bem que Saussure só pôde escapar a esta vocação diacrônica da filologia restaurando a relação da linguagem com a representação, disposto a reconstituir uma 'semiologia' que, à maneira da gramática geral, define o signo pela ligação entre duas ideias.” (MC, p. 307, grifos meus)

Ora, ainda que a compreensão de Foucault da linguística saussuriana seja controversa $^{66}$ (sobretudo no que diz respeito a afirmação de que a concepção de signo de Saussure liga-se àquela de Port-Royal, logo, que ela se encontra submetida ao regime da representação), não seria esta uma maneira mostrar que o privilégio dado ao estruturalismo ao fim de As palavras e as coisas é, em certa medida, relativo? Isto é, que o estruturalismo, por um lado, encontra-se ligado a uma disposição já remota do saber e que, por outro lado, em sua própria época faz parte de um espaço de questionamento mais amplo, aquele instaurado por Nietzsche e Mallarmé? Como diz Foucault:

\begin{abstract}
a importância da linguística e da sua aplicação ao conhecimento do homem faz reaparecer, em sua insistência enigmática, a questão do ser da linguagem, sobre a qual vimos o quanto ela estava ligada aos problemas fundamentais da nossa cultura. Questão que a utilização cada vez mais ampla das categorias linguísticas torna ainda mais pesada, uma vez que é preciso doravante se perguntar o que deve ser a linguagem para estruturar assim o que não é, entretanto, por si mesmo, nem fala nem discurso, e para se articular sobre as
\end{abstract}

\footnotetext{
${ }^{66}$ Cf. François Wahl. "Há uma epistemê estruturalista? Ou de uma filosofia aquém do estruturalismo: Michel Foucault“. In: Estruturalismo e filosofia. São Paulo: Editora Cultrix, s.d., p. 41 seq. - Cf. MANIGLIER, Patrice. "The order of things". In: Christopher Falzon, Timothy O'Leary, Jana Sawicki (org.). A companion to Foucault. Blackwell Publishing, 2013, p.
} 
formas puras do conhecimento. Por um caminho muito mais longo e muito mais imprevisto, somos reconduzidos a este lugar que Nietzsche e Mallarmé haviam indicado quando um perguntara: Quem fala? e que o outro vira cintilar a resposta na própria Palavra. A interrogação sobre o que é a linguagem em seu ser retoma, mais uma vez, seu tom imperativo. (MC, p. 394)

Nesse sentido, não se encontraria em As palavras e as coisas, inclusive, uma crítica "discreta" ao estruturalismo, particularmente no que diz respeito à analise estrutural das obras literárias que, segundo Foucault foi feita pela primeira vez ${ }^{67}$, na França, por Lévi-Strauss e Jakobson ${ }^{68}$ ? Em contraposição ao elogio do estruturalismo nas últimas páginas, vemos Foucault dizer, no final do capítulo II, que, se na modernidade o "ser da linguagem" reaparece de uma maneira privilegiada na literatura, isto faz com que ela apareça:

como o que deve ser pensado; mas também, e pela mesma razão, como o que não poderá em nenhum caso ser pensado a partir de uma teoria da significação. Quer a analisemos do lado do significado (o que ela quer dizer, suas "idéias", o que ela promete ou o que exige), quer do lado do significante (com a ajuda de esquemas tomados à lingüística ou à psicanálise), pouco importa: isso não passa de um episódio. Tanto num caso como no outro, buscam-na fora do lugar onde, para nossa cultura, ela jamais cessou, desde há um século e meio, de nascer e de se imprimir. Tais modos de decifração provêm de uma situação clássica da linguagem — aquela que reinou no século XVII, quando o regime dos signos se tornou binário e quando a significação foi refletida na forma da representação; então a literatura era realmente composta de um significante e de um significado e merecia ser analisada como tal. A partir do século XIX, a literatura repõe à luz a linguagem no seu ser: não, porém, tal como ela aparecia ainda no final do Renascimento. Porque agora não há mais aquela palavra primeira, absolutamente inicial, pela qual se achava fundado e limitado o movimento infinito do discurso; doravante a linguagem vai crescer sem começo, sem termo e sem promessa. É o percurso desse espaço vão e fundamental que traça, dia a dia, o texto da literatura. (MC, p. 59, grifos meus)

Assim, através dessa espécie de ontologia histórica da linguagem que Foucault realiza em As palavras e as coisas, já não seria possível encontrar uma reflexão sobre a

\footnotetext{
67 "A análise da obra literária a partir de esquemas linguísticos [...] foi feita pela primeira vez na França por Lévi-Strauss, relativamente a um soneto de Baudelaire, em que ele mostrou como o soneto ['Les Chats'] era inteiramente comandado pelas possibilidades fonéticas que eram dadas à Baudelaire. Este último construiu esse soneto sobre um sistema de redundância do qual ele dispunha pelos caracteres fonéticos próprios da língua francesa. Este estudo, que permaneceu, finalmente, bastante desconhecido, bastante esquecido durante um certo número de anos, foi recentemente recolocado à luz. Atualmente, os trabalhos de Barthes e de Genette são inteiramente colocados nesta direção, [...] os esquemas linguísticos que eles utilizam não são aqueles da fonética, mas da sintaxe e da semântica. São essencialmente os esquemas da retórica que lhes servem de fio condutor para a análise das obras; isto supõe, bem entendido, que a própria obra literária não seja outra coisa senão um tipo de duplicação das estruturas linguísticas sobre si mesmas. Isto supõe que a obra literária seja a língua, manifeste-se ela mesma na sua estrutura e na sua virtualidade." - Michel Foucault. "Structuralisme et analyse litteraire". In: Les cahiers de Tunisie, Tomes XXXIX, $\mathrm{n}^{\circ}$ 149-150, $3^{\circ}-4^{\circ}$ trimestres, 1989, pp. 36-37.

${ }^{68}$ Roman Jakobson, Claude Lévi-Strauss. « Les Chats » de Charles Baudelaire. In: L'Homme, 1962, tome $2 \mathrm{n}^{\circ} 1$. pp. $5-21$.
} 
linguagem que buscaria definir o seu "ser" para além dos limites da "língua", isto é, do modo como a linguística estruturalista a definiu? E não seria esta inquietação que, ao mesmo tempo, teria levado Foucault, nesta obra, a apostar na possibilidade de realizar uma descrição dos discursos que, diferentemente do que ele havia feito nos seus livros anteriores, neutraliza, "mas sem abandonar o projeto de aí retornar um dia, todo o lado prático e institucional" (DE I, 71 p. 871), a fim de encará-los em sua dimensão de existência como "coisas ditas"? Ao menos, em vista do que tratamos neste trabalho e da seguinte declaração de Foucault, somos motivados a colocar tais questões - que poderemos procurar responder numa outra ocasião:

O problema que me preocupa, que de fato não cessou de me preocupar há dez anos, é este: em uma cultura como a nossa, em uma sociedade, o que é a existência das palavras, da escrita, do discurso? Pareceu-me que não se tinha, jamais, dado tanta importância ao fato de que, afinal, os discursos, isso existe [ça existe]. Os discursos não são somente um tipo de película transparente através da qual se vê as coisas, não são simplesmente o espelho do que é e do que se pensa. $\mathrm{O}$ discurso tem sua consistência própria, sua espessura, sua densidade, seu funcionamento. As leis do discurso existem como as leis econômicas. Um discurso, isso existe como um monumento, isso existe como uma técnica, isso existe como um sistema de relações sociais, etc.

É esta densidade própria do discurso que eu tento interrogar. [...] Os linguistas, eu sei bem, descobriram que a linguagem é muito importante porque ela obedece a leis, mas eles insistiram sobretudo na estrutura da língua, ou seja, na estrutura do discurso possível. Mas isto sobre o que eu me interrogo, é sobre o modo de aparição e de funcionamento do discurso real, sobre as coisas que foram efetivamente ditas. Trata-se de uma análise das coisas ditas na medida em que são coisas. ${ }^{69}$

\footnotetext{
${ }^{69}$ Michel Foucalt. Le beau danger - entretien avec Claude Bonnefoy. Paris: Éditions de l'École des hautes études em sciences sociales, 2011, pp. 34-35, grifos meus.
} 


\section{Referências bibliográficas}

\section{Bibliografia primária}

FOUCAULT, Michel. Dits et écrits - I. 1954-1975. Paris : Éditions Gallimard, 2001. . L'archéologie du savoir. Paris : Éditions Gallimard, 1969. Le beau danger - entretien avec Claude Bonnefoy. Paris: Éditions de l'École des hautes études em sciences sociales, 2011.

. Les mots et les choses. Paris : Éditions Gallimard, 1966.

. "Lettre de Michel Foucault du 8 mars 1967 en réponse à Michel Amiot". In: Les mots et les choses de Michel Foucault - regards critique 1966 - 1968. Caen: Presses universitaires de Caen, 2009.

. Naissance de la clinique. Paris : PUF, 2009.

. "Structuralisme et analyse litteraire". In: Les cahiers de Tunisie, Tomes XXXIX, no $149-150,3^{\circ}-4^{\circ}$ trimestres, 1989.

FOUCAULT, Michel; KANT, E. Anthropologie du point de vue pragmatique \& Introduction à l'Antropologie. Paris : Vrin, 2009.

\section{Bibliografia secundária}

ARNAULD, Antoine; NICOLE, Pierre. La logique ou l'art de penser. Paris: Éditions Gallimard, 1992.

BARTHES, Roland. "A atividade estruturalista". In: Eduardo Prado Coelho (org.). Estruturalismo - Antologia de textos teóricos. São Paulo: Martins Fontes, s.d.

. L'aventure sémiologique. Éditions du Seuil, 1985.

CANGUILHEM, Georges. "Mort de l'homme ou épuisement du Cogito ?". In: Les mots et les choses de Michel Foucault - regards critiques 1966-1968. Caen: Presses universitaires de Caen, 2009. 
CHAPSAL, Madeleine. "La plus grande révolution depuis l'existentialisme". In: Les mots et les choses de Michel Foucault - regards critiques 1966-1968. Caen: Presses universitaires de Caen, 2009.

CHÂTELET, François. "L'homme, ce Narcisse incertain”. In: Les mots et les choses de Michel Foucault - regards critiques 1966-1968. Caen: Presses universitaires de Caen, 2009.

COELHO, Eduardo Prado. "Introdução a um pensamento cruel: estruturas, estruturalidade e estruturalismos". In: Eduardo Prado Coelho (org.). Estruturalismo Antologia de textos teóricos. São Paulo: Martins Fontes, s.d.

DE CERTEAU, Michel. Histoire et psychanalyse - entre science et fiction. Paris: Éditions Gallimard, 1987.

DELEUZE, Gilles. A ilha deserta e outros textos - textos e entrevistas (1953-1974). São Paulo: Editora Iluminuras, 2006. . Foucault. Paris: Les Éditions de Minuit, 2004.

DOSSE, François. História do estruturalismo: I. O campo do signo, 1945/1966. São Paulo; Campinas: Ensaio; Editora da Unicamp, 1993.

DREYFUS, Hubert L.; RABINOW, Paul. Michel Foucault - uma trajetória filosófica para além do estruturalismo e da hermenêutica. Rio de Janeiro: Forense Universitária, 2010.

DUCROT, Oswald; TODOROV, Tzvetan. Dictionnaire encyclopédique des sciences $d u$ langage. Paris: Éditions du Seuil, 1972.

GROS, Frédéric. Foucault et la folie. Paris : PUF, 1997.

GUTTING, Gary. Michel Foucault's archaeology of scientific reason. Cambridge: Cambridge University Press, 1989.

JAKOBSON, Roman; LÉVI-STRAUSS, Claude. "'Les Chats' de Charles Baudelaire". In: L'Homme, 1962, tome $2, \mathrm{n}^{\circ} 1$.

KOYRÉ, Alexandre. "Orientation et projets de recherché". In: Études d'histoire de la pensée scientifique. Éditions Gallimards, 1973.

. "Perspectives sur l'histoire des sciences". In: Études d'histoire de la pensée scientifique. Éditions Gallimards, 1973.

LE BLANC, Guillaume. La pensée Foucault. Paris: Ellipses Édition, 2006

LEBRUN, Gérard. "Transgredir a finitude". In: Recordar Foucault. São Paulo: Editora Brasiliense, 1985.

"Note sur la phénoménologie dans Les mots et les choses". In: Michel Foucault philosophe - rencontre internationale Paris 9, 10, 11 janvier 1988. Paris: Seuil, 1989. 
MACHADO, Roberto. Foucault, a ciência e o saber. Rio de Janeiro: Jorge Zahar Editor, 2006.

Foucault, a filosofia e a literatura. Rio de Janeiro: Jorge Zahar Editor, 2005.

MANIGLIER, Patrice. “The order of things”. In: Christopher Falzon, Timothy O'Leary, Jana Sawicki (org.). A companion to Foucault. Blackwell Publishing, 2013.

La vie énigmatique des signes - Saussure et la naissance du structuralisme. Éditions Léo Scheer, 2006.

MANZI, Ronaldo Filho. "Duas noções de a priori histórico: a tradição e o arquivo - a concepção de uma 'anti-crise' de Michel Foucault. In: Philósophos - revista de filosofia. Vol. 19, n 1 , ano 2014, pp. 191-217.

ORTIGUES, Edmond. Le discours et le symbole. Paris: Beauchesne, 2007.

POTTE-BONNEVILLE, Mathieu. "Du sable à la bataille: Foucault avant 1968". In: MANIGLIER, Patrice (org.). Le moment philosophique des années 1960 em France. Paris: PUF, 2011. . Foucault. Paris: Ellipses Édition, 2010.

SABOT, Philippe. Lire "Les mots et les choses" de Michel Foucault. Paris: PUF, 2006. Le Même et l'Ordre - Michel Foucault et le savoir à l'âge classique. Lyon: ENS Éditions, 2015, p. 58

SALANSKIS, Jean-Michel. Herméneutique et cognition. Paris: Presses Universitaires du Septentrion, 2003

SARDINHA, Diogo. Ordre et temps dans la philosophie de Foucautl. Paris: L'Harmattan, 2011.

SARTRE, Jean-Paul. "Jean-Paul Sartre répond". In: Les mots et les choses de Michel Foucault - regards critiques 1966-1968. Caen: Presses universitaires de Caen, 2009, pp. 75-76.

SAUSSURE, Ferdinand de. Cours de linguistique générale. Paris: Éditions Payot \& Rivage, 2005.

TERNES, José. Michel Foucault e a idade do homem. Goiânia: Editora da UCG, Editora da UFG, 2009.

WAHL, François. Estruturalismo e filosofia. São Paulo: Cultrix, s.d..

WEBB, David. "Cavaillès and the historical a priori in Foucault". In: Simon Duffy (org.). Virtual Mathematics - the logic of difference. Bolton: Clinamen Press, 2006.

Foucault's archaeology - science and transformation. Edinburgh: Edinburgh University Press, 2013. 